Review

\title{
Review of Biohydrometallurgical Metals Extraction from Polymetallic Mineral Resources
}

\author{
Helen R. Watling \\ CSIRO Mineral Resources Flagship, PO Box 7229, Karawara, WA 6152, Australia; \\ E-Mail: Helen.Watling@csiro.au; Tel.: +61-8-9334-8034; Fax: +61-8-9334-8001 \\ Academic Editor: Karen Hudson-Edwards
}

Received: 30 October 2014 / Accepted: 10 December 2014 / Published: 24 December 2014

\begin{abstract}
This review has as its underlying premise the need to become proficient in delivering a suite of element or metal products from polymetallic ores to avoid the predicted exhaustion of key metals in demand in technological societies. Many technologies, proven or still to be developed, will assist in meeting the demands of the next generation for trace and rare metals, potentially including the broader application of biohydrometallurgy for the extraction of multiple metals from low-grade and complex ores. Developed biotechnologies that could be applied are briefly reviewed and some of the difficulties to be overcome highlighted. Examples of the bioleaching of polymetallic mineral resources using different combinations of those technologies are described for polymetallic sulfide concentrates, low-grade sulfide and oxidised ores. Three areas for further research are: (i) the development of sophisticated continuous vat bioreactors with additional controls; (ii) in situ and in stope bioleaching and the need to solve problems associated with microbial activity in that scenario; and (iii) the exploitation of sulfur-oxidising microorganisms that, under specific anaerobic leaching conditions, reduce and solubilise refractory iron(III) or manganese(IV) compounds containing multiple elements. Finally, with the successful applications of stirred tank bioleaching to a polymetallic tailings dump and heap bioleaching to a polymetallic black schist ore, there is no reason why those proven technologies should not be more widely applied.
\end{abstract}

Keywords: polymetallic; concentrates; tailings; black shales; bioleaching; mine wastes; sulfide ores; oxidised ores 


\section{Introduction}

Currently, there are strong drivers to become more efficient in metal extraction because, for some metals, discoveries of new high-grade deposits or large low-grade deposits are too few to match the predicted growing demand. Cases in point are copper, for which there is already a supply deficit that is likely to continue and zinc, for which the surplus of recent years (Figure 1) is likely to become a deficit. With 16 planned zinc mine closures in the period 2013-2017 and a predicted increase in consumption from 13.5 to $20.5 \mathrm{Mt}$ by 2025 [1], the zinc deficit could increase to as much as $30 \%$ of zinc production. These two metals with a long history are seemingly indispensable to the well being of developed nations. Other "indispensable" metals include:

- Ta, In, Ru, Ga, Ge and Pd used in electrical and electronic equipment,

- Ga, Te, In and Ge in photovoltaic cells,

- Co, Li and rare earths in batteries, and

- $\quad \mathrm{Pt}, \mathrm{Pd}$ and rare earths in catalysts [2].

Conclusions based on the analysis of an extensive data set for the use of seven metals ( $\mathrm{Ag}, \mathrm{Ni}, \mathrm{Pb}$, $\mathrm{Cr}, \mathrm{Zn}, \mathrm{Cu}$ and $\mathrm{Fe}$ ) in 49 countries [3], were that: (i) per capita metal use is more than 10 times the global average in developed countries; (ii) countries that use more than the average of any metal do so for all metals; and (iii) as wealth and technology increase in developing countries, there will be strong demand for all industrial metals. The growth of the mobile phone industry provides a good example. Mobile phones have become an important means of communication worldwide. Sales rose from about 100 million in 1997 to nearly a billion in 2009, more than six billion phones in the period [4]. The raw materials required for their production are mined around the world and, while the amounts per mobile range from small to trace, the amounts required for a billion phones (annual production) measure in tonnes: 15,000 Cu, $3000 \mathrm{Fe} / \mathrm{Al}, 2000 \mathrm{Ni}, 1000 \mathrm{Sn}, 500 \mathrm{Ag},<100 \mathrm{Au}, \sim 15 \mathrm{Pd}, \sim 4 \mathrm{Ta}$ and $\sim 2 \mathrm{In}$ [4].

Based on known reserves, and consumption and disposal at current rates, it was estimated [5] that the elements $\mathrm{Zn}, \mathrm{Ga}, \mathrm{Ge}, \mathrm{As}, \mathrm{Rh}, \mathrm{Ag}$, In, Sn, Sb, Hf and Au will be exhausted within 50 years, and that $\mathrm{Ni}, \mathrm{Cu}, \mathrm{Cd}, \mathrm{Tl}$ and $\mathrm{U}$ will be exhausted within 100 years. Estimates of the same order for metals depletion within 50 years $(\mathrm{Cu}, \mathrm{Pb}, \mathrm{Mn}, \mathrm{Ag}, \mathrm{Sn}, \mathrm{Zn})$ and within 100 years (Fe, Ni, U) were obtained independently [6] and it was suggested that the platinum group metals would be exhausted in 150 years. Estimates such as these highlight the need for new discoveries, more efficient element extraction from known reserves, the processing of mine waste or tailings and the recycling of industrial and urban metal-rich waste The focus of this review is on the extraction of metals from minerals, specifically polymetallic ores, waste or tailings, using proven biotechnologies and highlighting some innovative potential variants.

The declining grades of Australian ores (Figure 2) is representative of declining grades in other mining regions [7]. However, greatly improved process efficiencies have made it possible to extract metals economically from ores of much lower grade than those processed historically. Thus, part of the apparent decline can be attributed to the processing of lower-grade ores, when these are accounted in statistical analyses [8,9]. Nevertheless, in the absence of new discoveries of sufficiently large deposits of high-grade ores containing the targeted elements, there is a need to process ores of generally lower grade than was the case in the 20th century. 

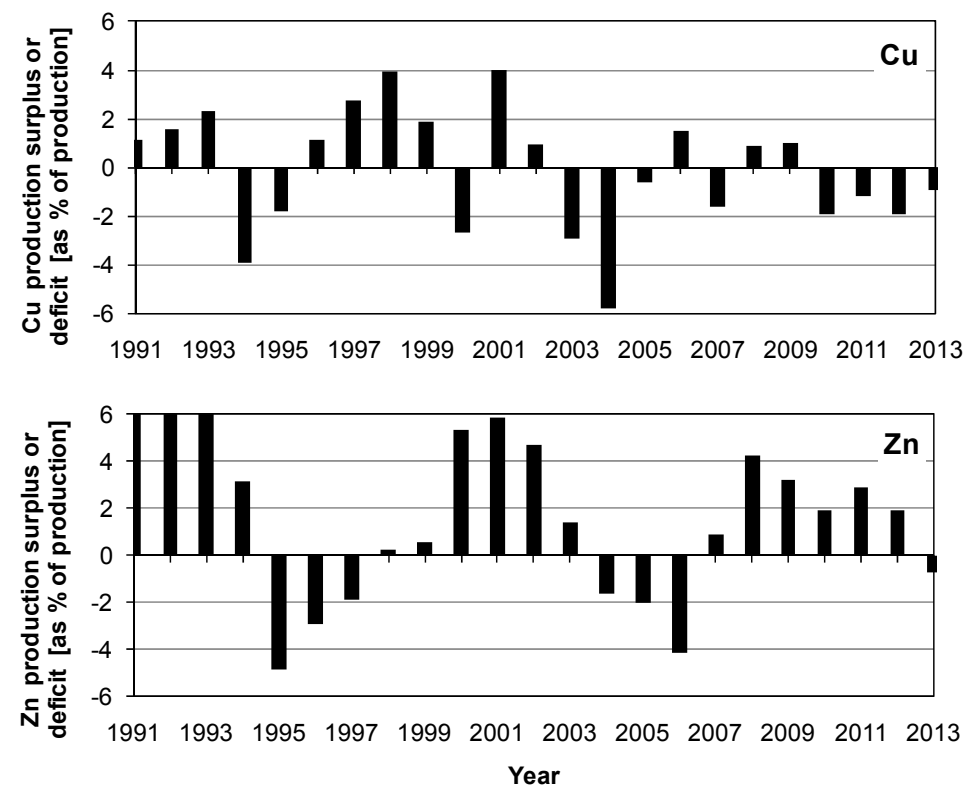

Figure 1. Supply/demand relationships for copper and zinc; annual surpluses and deficits are shown as percentages of total annual production (data from [10-12]).

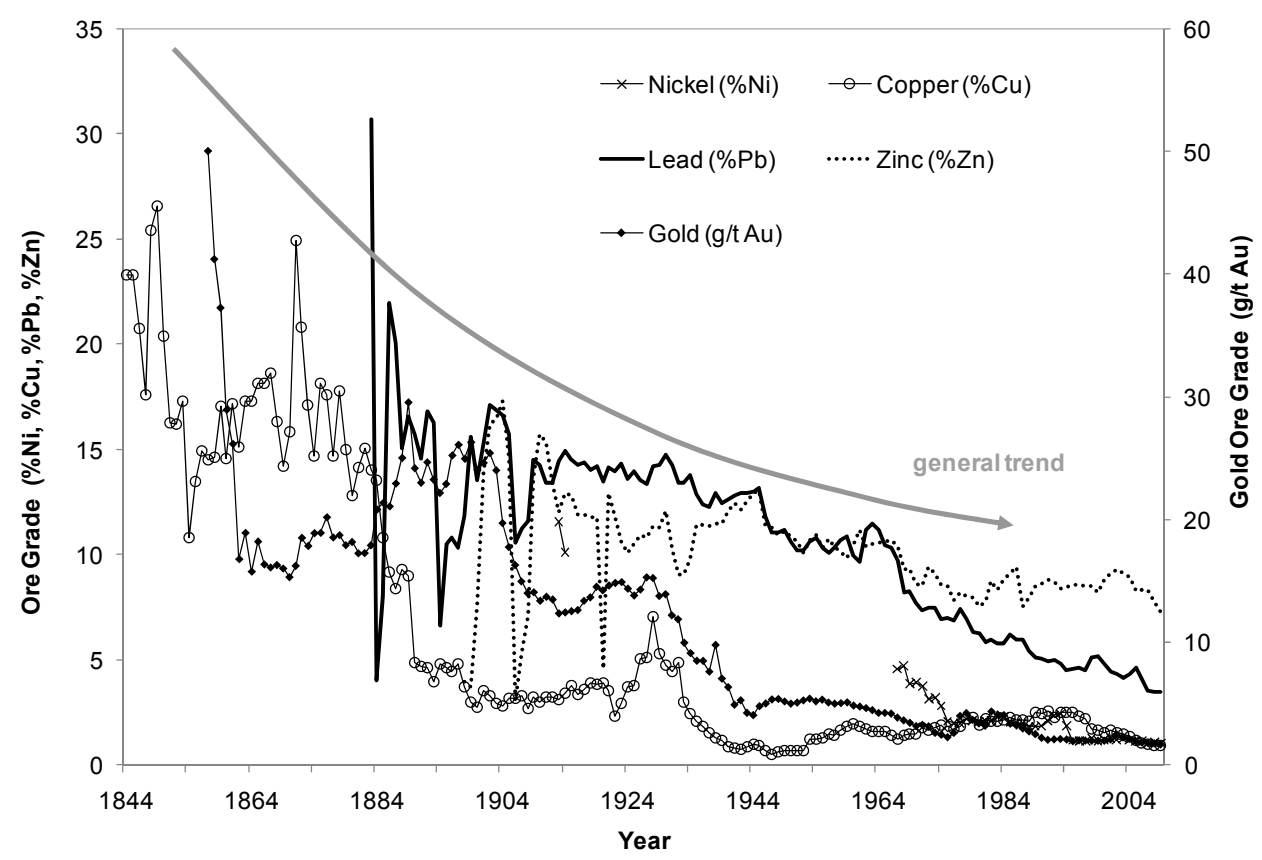

Figure 2. Declining grades of Australian base and precious metal ores. Reproduced with permission from Prior et al. [7].

In respect of the greater mineralogical complexity of polymetallic materials, there is a need to develop efficient technologies that recover a suite of metals rather than a single metal, from resources for which the considerable costs of resource definition, mining and ore processing, and waste management are unavoidable, should a decision to construct and operate a commercial plant be undertaken. "Ancillary" metals co-extracted, separated and purified may make the processing of some complex ores economic where the production of a single metal does not. At the same time, alternative sources of metals should be sought and tested. Historically, thousands of tonnes of metal values lie in 
waste ores and tailings abandoned at mine sites because today's more efficient metal extraction technologies were not available at the time.

In this review the roles and contributions of microorganisms in mineral bioprocessing are briefly reviewed, and bioleaching and biooxidation technologies trialled at pilot scale or demonstration scale, or implemented commercially are described. Examples are taken from publicly-available literature on the bioprocessing of polymetallic mineral resources including ores, concentrates and tailings. Ores are sulfidic or lateritic, or low- or high-organic content (shales or schists).

There are many applications in which microorganisms mobilise or immobilise elements in the environment using innovative biochemical processes. However, those processes and applications of bioleaching, biooxidation and bioreduction not targeting metals extraction have been excluded in order to keep the review to manageable size. In addition, the review does not include data on metal recovery from manufactured products, sludges, electronic waste, etc.; topics for which there are already substantial bodies of literature, including some informative reviews [13-18].

\section{The Chemistry and Microbiology of Mineral Dissolution}

The deliberate exploitation of microorganisms in the process of extracting metals (mainly copper) from ores under acidic conditions has an extremely long history, even though the roles of those microorganisms in both extraction and the generation of acid rock drainage (ARD) were not originally recognised. Some thirty years prior to the "discovery" of Thiobacillus ferrooxidans, now Acidithiobacillus (At.) ferrooxidans [19], a possible biological method for the "economic utilization of low-grade zinc sulphide ores" was proposed [20]. Broader recognition of bacterial roles followed from studies of ARD associated with bituminous coal [21-23] and copper mine waste dumps [24-26].

Laboratory-scale studies on the extraction of metals from sulfide minerals followed, initially on the application of At. ferrooxidans and/or At. thiooxidans, but expanding to include newly discovered microorganisms that also enhanced the dissolution rates of many sulfide minerals under acidic conditions [27-30]. Not surprisingly, the main focus of these studies was on microbial iron(II) oxidation and reduced inorganic sulfur compound (RISC) oxidation, the two key microbial capabilities for metals extraction. At the same time, the possible exploitation of heterotrophic microorganisms in the leaching of oxidised silicate ores was tested [31-33] and the important roles of heterotrophic bacteria in bioleaching were studied $[34,35]$.

The main functions of microorganisms useful in bioleaching were readily elucidated because the microorganisms accelerated already understood chemical reactions. From a processing point of view, the microbial functions were considered to be catalytic. However, biohydrometallurgists worldwide have pursued fundamental research on the physiology of microbiological functions and increasingly developed novel approaches to their exploitation either for metals extraction for commercial purposes or remediation of acid rock drainage (ARD). Not surprisingly, with the development of sophisticated experimental and analytical tools, including the application of deoxyribonucleic acid (DNA)-based techniques, a wealth of knowledge about the activities of microorganisms present in bioleaching or ARD environments has been described and discussed in numerous research articles and some recent reviews [36-39]. Only brief summaries of the leaching chemistry and microbial characteristics that assist mineral dissolution are presented in this review. 


\subsection{Mineral Dissolution in Acidic Environments}

Acid leaching of ores or sediments involves the dissolution of minerals. Some minerals dissolve congruently (e.g., calcite, reaction (1)), in which case the resulting soluble species have the same stoichiometry as the source material. Other minerals dissolve incongruently (e.g., biotite, reaction (2)) in reactions that generate soluble species not representative of the source mineral stoichiometry and one or more secondary insoluble minerals.

$$
\begin{gathered}
\mathrm{CaCO}_{3}+2 \mathrm{H}^{+} \rightarrow \mathrm{Ca}^{2+}+\mathrm{CO}_{2}(\text { gas })+\mathrm{H}_{2} \mathrm{O} \\
2 \mathrm{~K}\left(\mathrm{Fe}^{\mathrm{II}}{ }_{1.5} \mathrm{Mg}_{1.5}\right) \mathrm{AlSi}_{3} \mathrm{O}_{10}(\mathrm{OH})_{2}+14 \mathrm{H}^{+}+7.5 \mathrm{H}_{2} \mathrm{O}+0.75 \mathrm{O}_{2} \rightarrow \\
2 \mathrm{~K}^{+}+3 \mathrm{Mg}^{2+}+2 \mathrm{Al}^{3+}+6 \mathrm{H}_{4} \mathrm{SiO}_{4}+3 \mathrm{Fe}(\mathrm{OH})_{3}
\end{gathered}
$$

The important role of iron chemistry in bioleaching environments should not be forgotten because it is inextricably linked with ore mineralogy, mineral dissolution and solution acidity. Ferric ions in bioleaching solutions containing sulfate anions (from sulfuric acid) and monovalent cations $\left(\mathrm{Na}^{+}, \mathrm{K}^{+}\right.$ from the dissolution of carbonate or silicate minerals) readily form insoluble iron(III) hydroxides, oxides, sulfates or hydroxysulfates, or mixtures of them, depending on the composition and acidity $(\mathrm{pH})$ of the solutions. A guide to the conditions of formation of the iron(III) precipitates most often detected in bioleached residues [40] is as follows:

Ferrihydrite (approximate formula $5 \mathrm{Fe}^{\mathrm{III}}{ }_{2} \mathrm{O}_{3} \cdot 9 \mathrm{H}_{2} \mathrm{O}$ ): Formation is favoured in solutions of $\mathrm{pH}>5$. Other elements can be adsorbed from solution onto ferrihydrite [41,42]. Ferrihydrite is a poorly crystalline compound that in solution $\mathrm{pH} 2-5$, transforms to goethite (reaction $(3)$ ) $[43,44]$.

Goethite $\left(\mathrm{Fe}^{\mathrm{III}} \mathrm{OOH}\right)$ : Formation is favoured from solutions of $\mathrm{pH}>4$ with low sulfate concentrations $[43,45]$.

Schwertmannite (approximate formula $\mathrm{Fe}^{\mathrm{III}}{ }_{8} \mathrm{O}_{8}(\mathrm{OH})_{6} \mathrm{SO}_{4}$ ): Formation is favoured in solutions of pH 3-4 containing moderate to high ferric sulfate but low monovalent cation concentrations [46]. Various elements can be adsorbed from solution onto schwertmannite [47-49]. Schwertmannite is poorly crystalline and unstable and transforms to either goethite (reaction (4)) [45,50] or jarosite (reaction (5)) $[51,52]$.

Jarosite $\left(\left(\mathrm{Na}, \mathrm{K}, \mathrm{H}_{3} \mathrm{O}^{+}, \mathrm{NH}_{4}^{+}\right) \mathrm{Fe}^{\mathrm{III}}{ }_{3}\left(\mathrm{SO}_{4}\right)_{2}(\mathrm{OH})_{6}\right)$ : Formation is favoured in solutions of $\mathrm{pH}$ 1.7-2.3 containing monovalent cations, moderate to high ferric ion and sulfate concentrations. Conditions such as these prevail in most laboratory-scale batch bioleaching tests because the microbial culture medium contains potassium and ammonium salts and the leaching is conducted at solution pH 1.5-2 [46,53].

$$
\begin{gathered}
\mathrm{Fe}_{2} \mathrm{O}_{3} \cdot 9 \mathrm{H}_{2} \mathrm{O}+\mathrm{H}_{2} \mathrm{O} \rightarrow 2 \mathrm{FeOOH}+9 \mathrm{H}_{2} \mathrm{O} \\
\mathrm{Fe}_{8} \mathrm{O}_{8}\left(\mathrm{SO}_{4}\right)(\mathrm{OH})_{6}+2 \mathrm{H}_{2} \mathrm{O} \rightarrow 8 \mathrm{FeOOH}+\mathrm{H}_{2} \mathrm{SO}_{4} \\
\mathrm{Fe}_{8} \mathrm{O}_{8}\left(\mathrm{SO}_{4}\right)(\mathrm{OH})_{6}+0.5 \mathrm{~K}^{+}+\mathrm{SO}_{4}{ }^{2-}+16.5 \mathrm{H}^{+} \rightarrow \\
\left(\mathrm{H}_{3} \mathrm{O}_{0.5} \mathrm{~K}_{0.5}\right) \mathrm{Fe}_{3}\left(\mathrm{SO}_{4}\right)_{2}(\mathrm{OH})_{6}+5 \mathrm{Fe}^{3+}+18.5 \mathrm{H}_{2} \mathrm{O}
\end{gathered}
$$

\subsection{Bio-Generation of Inorganic Acids}

Mineral structures can be weakened through the action of microbially-generated inorganic acids such as nitric and nitrous acids, sulfuric and sulfurous acids, and carbonic acid [54,55]. Sulfuric and 
sulfurous acids are produced by Acidithiobacillus species as well as Thiothrix, Beggiatoa [56] and some fungi [57]. Nitric and nitrous acids are produced by ammonia and nitrite oxidising organisms, heterotrophic nitrifying organisms and some fungi [58-60]. Carbonic acid is the end product of energy metabolism when carbon dioxide reacts with water but it is a weak acid and unlikely to contribute greatly to mineral dissolution with the exception of carbonate minerals [55].

Sulfuric acid is most often the acid responsible for low-pH leaching environments and is produced by the oxidation of RISCs such as sulfur (reaction (6)). Naturally occurring RISCs are present wherever sulfide minerals are exposed to air and moisture [61]. In the oxidation reaction, the RISC is the electron donor and oxygen is the electron acceptor. Theoretically the amount of energy obtained by microorganisms during RISC (bio)oxidation to sulfate is much greater than when iron(II) is (bio)oxidised [62].

$$
2 \mathrm{~S}^{\circ}+3 \mathrm{O}_{2}+2 \mathrm{H}_{2} \mathrm{O}+\text { microbial catalysts } \rightarrow 2 \mathrm{H}_{2} \mathrm{SO}_{4}
$$

\subsection{Bio-Generation of Organic Acids and Chelating Agents}

All microorganisms can excrete organic acids especially when growth is unbalanced [54]. Lactic acid bacteria and acetic acid bacteria are well known and mineral weathering by fungi (and algae) largely occurs through organic acid production [63].

Organic acids, such as oxalic, citric, gluconic, malic and succinic acids, together with amino acids, nucleic acids and uronic acids, can dissolve minerals via salt formation and complexation reactions $[55,64,65]$. Organic acids adhere to mineral surfaces and extract nutrient elements from mineral particles by electron transfer. Oxygen links in minerals are broken and ions present in solution are chelated via carboxyl and hydroxyl functional groups [66,67]. Polyfunctional acids like oxalic acid enhance the dissolution of silicates by creating an imbalance between cation and anion concentrations in solution [68-72] but they can also protect calcareous rocks through the formation of, for example, calcium oxalate films [73,74]. Sterflinger [75] collated fungal species reported to colonise building stones (sandstone, marble and granite) and, where known, listed the acids produced by them. In many studies on the bioleaching of oxidised ores such as nickel laterites, the aim was to exploit organic acid production by selected fungi such as Aspergillus species to extract nickel and cobalt [33,76,77].

Siderophores are a group of organic compounds produced by microorganisms to obtain iron in circumstances of low iron availability [78]. Microbial siderophores contain carbonyl structures and have a strong affinity for iron(III) and manganese(III), which they can chelate and transport into cells [79-81]. In specific studies, siderophores have been shown to promote the dissolution of manganese oxides and hematite in the presence of organic acids [82,83]. Siderophores and organic acids act synergistically, the microorganism and/or organic acid interacting with the mineral surface and extracting iron or manganese from the mineral, and the siderophore chelating the iron in solution, thus reducing the free iron concentration and driving the dissolution reaction [82].

\subsection{Biodegradation of Organo-Metallic Compounds}

Deposits of interest in this review include the black schists and shales, for which there are considerable data on ore geochemistry and ore genesis. Black schists in Finland encountered as 
interlayers in mica schists contain $1 \%-2 \%$ of non-carbonate carbon and those associated with serpentinite-quartz rock-skarn assemblages contain, on average, 7\% non-carbonate carbon [84,85]. The Chimiari shale of Pakistan contains 18\% carbon, part of which is carbonate (not quantified) [86]. The black shale horizon of the Kupferschiefer black shales, Poland, contains between 5\%-14\% organic matter of marine origin (type II kerogen) [87,88], including a range of metallo-porphyrins and metallo-porphyrin-derivatives that contained one or more of $\mathrm{Ni}, \mathrm{Pb}, \mathrm{Co}, \mathrm{Cu}, \mathrm{Mg}, \mathrm{Zn}, \mathrm{V}, \mathrm{Al}, \mathrm{Cr}$ ), as well as organo-metallic compounds that contained Sn, Te, W, Pt or Zr [89].

Studies of the bacterial diversity of black shales are an important part of understanding how deposits were formed but fewer studies detailing the diversity of culturable species have been found. Two strains of heterotrophic bacteria, Bacillus (B.) cereus and B. amyloliqueficiens, were isolated and used to extract metals (at $\mathrm{pH} 7$ ) from the organometallic component of Kupferschiefer black shale ore [90]. Recoveries after 24-28 days of leaching were $\mathrm{Cu}(2.5 \%)$, $\mathrm{Ni}(9.3 \%)$ and $\mathrm{Zn}(<0.01 \%)$. Isolates of heterotrophic bacteria that degraded organo-metallic components included Pseudomonas, Acinetobacter, Aeromonas, Brevibacillus, Microbacterium and Bacillus species [91-93]. Most of the isolates were able to utilise simple organic compounds, such as acids or sugars, one isolate was able to degrade phenanthrene (an aromatic hydrocarbon) and several isolates could degrade synthetic metallo-porphyrins [94]. All strains could grow on black shale ore as the sole energy and carbon source, resulting in a slightly increased dissolved organic carbon concentration $\left(14-16 \mathrm{mg} \cdot \mathrm{L}^{-1}\right)$ compared with the control $\left(10 \mathrm{~g} \cdot \mathrm{L}^{-1}\right)$ after 30 days.

DNA-based and other microbiological methods were used to enumerate and describe microbial communities to a depth of $1500 \mathrm{~m}$ in a deep borehole through sulfidic black schist [95]. The high microbial diversity comprised communities influenced by depth and differing mineralogical strata. Diverse bacterial communities similarly influenced by depth and sample mineralogy were also reported for a group of black shales from China [96]. Proteobacteria, actinobacteria and firmicutes were more dominant than other phyla and the communities changed progressively with the degree of black shale weathering. The roles of microorganisms in utilising and oxidising sedimentary organic matter were summarised [97], from which it was concluded that black shales supported aerobic heterotrophs, anaerobic heterotrophs such as sulfate reducing bacteria (SRB) and fermentative bacteria, chemoautotrophs (iron(II)- and sulfur oxidising bacteria) and methanogenic bacteria.

In the context of metals extraction, biodegradation of the organic matter in black schist and shale deposits is considered important because some of the values may be bound to organic matter. For example, metallo-porphyrins, which bind elements such as vanadium, nickel, molybdenum and rhenium, are considered to be the compounds most resistant to degradation. In a study using various defined mixed cultures containing species of Bacillus, Streptomyces, Burkholderia and/or Pseudomonas bacteria and a natural consortium of indigenous bacteria, it was shown that the degradation of synthetic $\mathrm{Cu}-, \mathrm{V}-, \mathrm{Ni}-$ and Fe-octaethylporphyrin compounds was slow [98]. Maximum extractions from the synthetic metallo-porphyrins were $80 \%, 72 \%$ and $4 \%$ in 8 weeks, while extractions from shale organic matter were $32 \%, 81 \%$ and $12 \%$ in 8 weeks, for $\mathrm{Cu}, \mathrm{Ni}$ and $\mathrm{V}$, respectively, under the test conditions. However, bacteria isolated from Kupferschiefer ore could grow in salts medium containing synthetic copper and cobalt metallo-porphyrins as the sole source of energy and carbon [99]. In those experiments the increase in metal extraction was accompanied by a decrease in dissolved organic carbon in the medium. Similarly, the same indigenous bacterial cultures grew in salts medium with 
ground black shale ore as sole energy and carbon source [94,100,101]. SEM or TEM visualization of black shale surfaces after 30 days of leaching revealed the surface corrosion caused by bacterial action and the accumulations of organic matter in cells [89,101].

\subsection{Bio-Participation in Redox Reactions}

Some bacteria and archaea are able to oxidise reduced species of manganese(II), iron(II), cobalt(II), copper(I), arsenic $\left(\mathrm{AsO}_{2}{ }^{-}\right)$or selenium $\left(\mathrm{SeO}_{4}{ }^{2-}\right.$ or $\left.\mathrm{SeO}_{3}{ }^{2-}\right)$ and others can reduce manganese(IV), iron(III), cobalt(III), arsenic $\left(\mathrm{AsO}_{4}{ }^{2-}\right)$ or selenium $\left(\mathrm{SeO}_{4}{ }^{2-}\right.$ or $\left.\mathrm{SeO}_{3}{ }^{2-}\right)$, obtaining energy from the reactions [102]. Well known examples are At. ferrooxidans and Leptospirillum (L.) ferrooxidans, both of which can obtain all of their energy for growth from the oxidation of iron(II) to iron(III). Less well known examples are Stibiobacter senarmontii, which obtains energy for growth from the oxidation of antimony(III) to antimony(V) [103] and Pseudomonas (Pm.) arsenitoxidans, which obtains energy from the oxidation of arsenic(III) to arsenic(V) [104]. In their comprehensive review on redox reactions of iron in acidic environments, Johnson et al. [105] discussed the diverse metabolic characteristics of acidophiles that catalyse iron redox transformations at low $\mathrm{pH}$ and the mechanisms employed by acidophiles engaged in iron oxidation and reduction, and described examples of iron cycling in acidic environments, including the degradation of iron(III) compounds under microaerobic or anaerobic conditions. The manganese(IV) mineral asbolane can be solubilised, releasing cobalt, and chromium is released from chromite mineral as the less toxic chromium(III) species [106].

\subsubsection{Fe(II) and RISC Biooxidation in Oxygenated Environments}

The dissolution of sulfidic minerals, the most widely applied biotechnology for the extraction of metals, requires the presence of an oxidant. Typically, the oxidant is ferric ions and the reactions take place in an oxidising environment. The sulfide moiety in most mineral sulfides is oxidised to sulfur, releasing the metal ion and, for iron-containing mineral sulfides such as chalcopyrite (reaction (7)), ferrous ions. Among sulfide minerals, pyrite is an exception, because oxidation yields sulfate rather than sulfur (reaction (8)). While ferric ions may be released directly during the dissolution of some gangue minerals, for example chamosite $\left(\mathrm{Fe}_{3} \mathrm{MgFe}_{3} \mathrm{MgI}_{5} \mathrm{AlSi}_{3} \mathrm{AlO}_{10}(\mathrm{OH})_{8}\right.$, the iron-rich end-member of the chlorite group of minerals, or nontronite $\left.\mathrm{Na}_{0.3} \mathrm{Fe}^{\mathrm{IIII}} 2(\mathrm{Si}, \mathrm{Al})_{4} \mathrm{O}_{10}(\mathrm{OH})_{2} \cdot n \mathrm{H}_{2} \mathrm{O}\right)$, a swelling clay found in some ores, it is mainly regenerated from ferrous ion oxidation by acidophilic microorganisms (reaction (9)). Many acidophiles can also oxidise the elemental sulfur or soluble polythionates formed in bioleaching environments to sulfate (reaction (6)).

$$
\begin{gathered}
\mathrm{CuFeS}_{2}+2 \mathrm{Fe}_{2}\left(\mathrm{SO}_{4}\right)_{3} \rightarrow 5 \mathrm{FeSO}_{4}+\mathrm{CuSO}_{4}+2 \mathrm{~S}^{0} \\
\mathrm{FeS}_{2}+7 \mathrm{Fe}_{2}\left(\mathrm{SO}_{4}\right)_{3}+8 \mathrm{H}_{2} \mathrm{O} \rightarrow 15 \mathrm{FeSO}_{4}+8 \mathrm{H}_{2} \mathrm{SO}_{4} \\
4 \mathrm{Fe}^{2+}+4 \mathrm{H}^{+}+\mathrm{O}_{2}+\text { microbial catalysts } \rightarrow 4 \mathrm{Fe}^{3+}+2 \mathrm{H}_{2} \mathrm{O}
\end{gathered}
$$

The oxidation of ferrous ions and sulfur are the key microbial functions exploited in managed acidic bioleaching processes for the extraction of metals from sulfide minerals. The advantage of the sulfide-chemical-microbial interactions is that the acidophilic microorganisms gain energy for growth from both iron(II) and sulfur oxidation while catalysing the breakdown of the sulfide mineral structure. 
Most of the microorganisms utilise carbon dioxide from the air as a carbon source and obtain phosphorus, nitrogen, potassium and micronutrients from the ore, thus minimising the need for, and costs of, microbial maintenance beyond that of providing a suitably acidic environment and a supply of air.

Iron(II)- and sulfur-oxidising acidophiles are relatively few in number (refer to [39] for an overview of biodiversity in acid environments and [40] for species found in heap or tank leaching bioreactors). More are being discovered/described each year using microbiological and molecular techniques for species identification and characterisation [38,107-109] and physico-chemical methods for monitoring substrate oxidation and growth under bioleaching conditions [110,111].

\subsubsection{RISC Biooxidation in Anoxic or Oxygen-Limited Environments}

Many acidophiles that oxidise iron(II) and RISCs in the presence of oxygen, also reduce iron(III) in the absence of oxygen (reaction (10)). For example, At. ferrooxidans uses RISCs as the electron donor and iron(III) as the electron acceptor [112] and also reduces molybdenum(VI) and copper(II) using elemental sulfur as an electron donor [113,114]. The most effective conditions of iron(III) reduction by Sulfobacillus (S.) thermosulfidooxidans, S. acidophilus and Acidimicrobium ferrooxidans were reported to be during mixotrophic or heterotrophic growth in oxygen-limited environments [115]. At. ferrooxidans growing on sulfur under aerobic conditions could, in the same reactor operated anaerobically, couple sulfur oxidation with iron(III) reduction and accelerate the dissolution of goethite in mildly acidic medium [116].

$$
\mathrm{CuFeS}_{2}+2 \mathrm{Fe}_{2}\left(\mathrm{SO}_{4}\right)_{3} \rightarrow 5 \mathrm{FeSO}_{4}+\mathrm{CuSO}_{4}+2 \mathrm{~S}^{0}
$$

\subsubsection{RISC Bioreduction in Anoxic or Oxygen-limited Environments}

In addition, heterotrophic acidophiles unable to oxidise iron(II), may nevertheless reduce iron(III) by coupling the reaction with the utilisation of organic compounds. For example, Acidicaldus organivorus grown on glucose (the electron donor) under anaerobic conditions used ferric ion as electron acceptor in an acid producing reaction (reaction (11)) [117]. Acidiphilium SJH reduced iron(III) in insoluble compounds such as amorphous ferric hydroxide $\left(\mathrm{Fe}^{\mathrm{III}}(\mathrm{OH})_{3}\right)$, akaganeite $\left(\beta-\mathrm{Fe}^{\mathrm{III}} \mathrm{O}(\mathrm{OH}, \mathrm{Cl})\right)$, goethite or jarosite [115]. In the case of schwertmannite, the reaction produced hydroxyl ions, resulting in raised $\mathrm{pH}$ (reaction (12)) [118]. Iron(III) mineral dissolution occurs indirectly because the bioreduction of soluble ferric ion under oxygen-limited conditions causes the solubility equilibrium between the iron(III) mineral phase and iron(III) in solution to become unbalanced and further mineral to dissolve [119].

$$
\begin{gathered}
24 \mathrm{Fe}^{3+}+\mathrm{C}_{6} \mathrm{H}_{12} \mathrm{O}_{6}+6 \mathrm{H}_{2} \mathrm{O} \rightarrow 24 \mathrm{Fe}^{2+}+6 \mathrm{CO}_{2}+24 \mathrm{H}^{+} \\
3 \mathrm{Fe}_{8} \mathrm{O}_{8}(\mathrm{OH})_{6}\left(\mathrm{SO}_{4}\right)+\mathrm{C}_{6} \mathrm{H}_{12} \mathrm{O}_{6}+6 \mathrm{H}_{2} \mathrm{O} \rightarrow 24 \mathrm{Fe}^{2+}+\mathrm{CO}_{2}+3 \mathrm{SO}_{4}{ }^{2-}+42 \mathrm{OH}^{-}
\end{gathered}
$$

In both modes of operation, either iron(III) reduction coupled with sulfur oxidation (reaction (10)) or iron(III) reduction coupled with utilisation of an organic compound (reaction (11)), there is a need to supply the electron donor, which adds to the cost of a process. Hallberg et al. [116] estimated that glycerol, a relatively low-cost, organic by-product of bio-diesel fuel production, was nevertheless more 
expensive than sulfur and that the use of sulfur had the additional advantage of lowering the amount of acid required to maintain solution acidity during mineral dissolution. They also noted that, in an "open" bioleaching system, acidophiles other than those that produce acid would colonise the reactor and compete for the supply of organic compound, adding to the cost of maintaining the necessary acidity for mineral dissolution.

$\mathrm{SRB}$ are ubiquitous in anoxic environments and play important roles in the carbon and sulfur cycles [120]. SRB may be beneficial in removing sulfate from wastewater but may cause problems through the production of sulfide which can be toxic and corrosive. An example of the use of SRB in the mining industry is a $500 \mathrm{~m}^{3}$ gas-lift reactor to treat zinc sulfate-containing process water at a zinc smelter [121]. In their review, Johnson and Hallberg [35] noted that only four genera of acidophilic archaea are known to grow anaerobically by the reduction of elemental sulfur: Acidianus, Stygiolobus, Sulfurisphaera and Thermoplasma, and that the majority of acid-tolerant or acidophilic SRB are sensitive to mild acidity (no growth at $\mathrm{pH}<5$ ). The strong sensitivity to acid would preclude their use in typical bioleaching environments.

\subsection{Microbial Growth under Element Stress}

A key challenge to microbial growth is solution chemistry. High concentrations of cations and anions build up in recycled process solutions during leaching. Thus, depending on the mineral concentrate and processing conditions, concentrations in stirred tank leachates may be up to $\left(\mathrm{g} \cdot \mathrm{L}^{-1}\right)$ : $\mathrm{Zn} 65, \mathrm{Fe} 60, \mathrm{Cu} 35, \mathrm{Ni} 25, \mathrm{As} 20, \mathrm{Co} 5, \mathrm{Mg}<1$, and $\mathrm{SO}_{4}{ }^{2-}$ 145. Solution ionic strengths up to $8.5 \mathrm{M}$ (estimated assuming ideal conditions) may exist and are especially influenced by iron(III) and sulfate ion concentrations and different concentrations exist in primary, secondary and tertiary tanks [122]. Concentrations are markedly different in heaps or dumps because of gangue mineral dissolution, $\mathrm{pH}$ gradients with depth and the condition of unsaturated leaching, which results in spatial variations in effective contact between particles of the target minerals and the percolating solution. Thus recycled heap solutions may contain $\left(\mathrm{g} \cdot \mathrm{L}^{-1}\right)$ : $\mathrm{Fe} 25, \mathrm{Al} 25, \mathrm{Zn} \mathrm{23,} \mathrm{Mg} \mathrm{10}, \mathrm{Cu} 6$, Ni 5, As 8, Co $<1$ and $\mathrm{SO}_{4}{ }^{2-}$ 130. Solution ionic strengths up to $7.6 \mathrm{M}$ have been estimated for heap process solutions, reflecting the high $\mathrm{Fe}^{3+}, \mathrm{Al}^{3+}$ and $\mathrm{SO}_{4}^{2-}$ concentrations.

Several accounts of microbial adaptation to arsenic emerged as a result of the commercialisation of biooxidation plants for the treatment of gold-containing arsenopyrite concentrates. A mixed culture in a $40 \mathrm{wt} \%$ arsenopyrite slurry became adapted to growth in a $\mathrm{pH} 0.5$ solution containing $27 \mathrm{~g} \cdot \mathrm{L}^{-1}$ As and $90 \mathrm{~g} \cdot \mathrm{L}^{-1} \mathrm{Fe}$ [123]. That culture was shown to oxidise both iron(II) and sulfur in a $\mathrm{pH} 0.9$ solution, and to oxidise iron(II) in a $\mathrm{pH} 2.3$ solution. Evidence of adaptation to arsenic was also obtained during the development of the $\mathrm{BIOX}^{\mathrm{TM}}$ process. After two years of continuous pilot-scale operation, the required retention time was reduced from 12 to 3.5 days in solutions of $13 \mathrm{~g} \cdot \mathrm{L}^{-1}$ As [124]. Similarly, during the development of the Bacox process [125], a moderately thermophilic culture was adapted to $25 \mathrm{~g} \cdot \mathrm{L}^{-1}$ As, much higher than the $6 \mathrm{~g} \cdot \mathrm{L}^{-1}$ subsequently present in plant process solution.

Descriptions of the piloting and demonstration plants for copper, nickel, cobalt and zinc are lacking in direct evidence of microbial adaptation. In a cobalt process, the microorganisms grew in process solution with $>5 \mathrm{~g} \cdot \mathrm{L}^{-1} \mathrm{Co}$ [126] and mineral oxidation was three times faster in continuous reactors 
than in batch reactors [127]. In a nickel process, the microorganisms grew in process solution with up to $23 \mathrm{~g} \cdot \mathrm{L}^{-1} \mathrm{Ni}$ and $38 \mathrm{~g} \cdot \mathrm{L}^{-1} \mathrm{Fe}$ [128], and in a high-temperature copper process, microorganisms grew in process solution with up to $36 \mathrm{~g} \cdot \mathrm{L}^{-1} \mathrm{Cu}$ and could be adapted to $45 \mathrm{~g} \cdot \mathrm{L}^{-1} \mathrm{Cu}$ [129]. Given that these concentrations are much higher than those encountered in most metalliferous environments, it can be inferred that the microorganisms have adapted to the extreme environments encountered in tank leaching. The report that active bacterial strains were present in mine water with up to $12 \mathrm{~g} \cdot \mathrm{L}^{-1}$ $\mathrm{U}_{3} \mathrm{O}_{8},[130]$ is also considered to be indirect evidence of adaptation.

Anions in process water also affect the growth and activity of microorganisms. While it might be expected that the highest concentrations would occur in the more intense tank leaching processes, this is not always the case. Sulfate concentrations can be up to 145 or $130 \mathrm{~g} \cdot \mathrm{L}^{-1}$ in tanks and heaps, respectively. In laboratory studies, cell replication was halved when a mixed mesophilic culture was "adapted" to $40 \mathrm{~g} \cdot \mathrm{L}^{-1} \mathrm{SO}_{4}{ }^{2-}$ [131]. Thus microbial adaptation can be inferred from the success of bioleaching in process waters of high sulfate concentrations.

Chloride in process water inhibits iron(II) oxidation more so than sulfur oxidation and microbial growth [132-134]. Although examples of the use of salt-tolerant cultures for ore leaching in process solutions with up to $115 \mathrm{~g} \cdot \mathrm{L}^{-1}$ total dissolved solids [135] or of the use of a salt-tolerant strain of Leptospirillum sp. in heap leaching [136] have been reported, details of the organisms, conditions and duration of adaptation and the limits of sulfur- or iron(II)-oxidation were not reported for either study. However, a mixed population of acidophiles, dominated by an L. ferriphilum strain, grew under extreme conditions $\left(\mathrm{g} \cdot \mathrm{L}^{-1}\right): 0.50 \mathrm{Cd}^{2+}, 3.75 \mathrm{Cu}^{2+}, 0.2 \mathrm{~Pb}^{2+}, 92 \mathrm{Zn}^{2+}, 6.4 \mathrm{Na}^{+}, 5.5 \mathrm{Cl}^{-}, 154 \mathrm{SO}_{4}^{2-}$ and total dissolved solids 393.8 (ionic strength $7.47 \mathrm{M}$ ) extracting up to $78 \% \mathrm{Cu}$ and $70 \% \mathrm{Zn}$ from a polymetallic concentrate [137].

Fluoride in process water presents a greater challenge than chloride. Concentrations greater than $0.5 \mathrm{~g} \cdot \mathrm{L}^{-1} \cdot \mathrm{F}$ are considered to be problematic to microbial growth [129]. However, if fluoride release to solution is accompanied by strong aluminium or iron solubilisation from gangue minerals, then the effects on the microorganisms may be substantially mitigated, due to the formation of complexes [138-142].

The impacts of nitrate ions on microorganisms inhabiting heaps have received less attention. Studies using At. ferrooxidans as the test organism showed that $6 \mathrm{~g} \cdot \mathrm{L}^{-1} \mathrm{NaNO}_{3}$ inhibited iron(II) oxidation by $40 \%$; in the same study iron(II) oxidation was arrested by $8 \mathrm{~g} \cdot \mathrm{L}^{-1}$ [143]. Nitrate was more inhibitory to iron(II) oxidation than sulfur oxidation by At. ferrooxidans [143,144]. However, a recent comparison of the effects of nitrate on substrate utilisation by bacteria and archaea capable of both iron(II)- and sulfur-oxidation showed that mesophilic and moderately thermophilic bacteria adapted to the presence of nitrate and resumed iron(II) oxidation, but iron(II) oxidation by the archaea was suppressed for the duration of the 12-week experiment [111].

\subsection{Technology Developments}

Different bioleaching technologies have been developed and/or refined during the last 65 years. They include some novel designs tested at laboratory and pilot scale but not finding wide industry acceptance: the flood-drain bioreactor, the aerated trough bioreactor, the airlift bioreactor and the rotating-drum bioreactor. 
The flood-drain bioreactor [145,146] comprises a lined container with a perforated-pipe solution distribution system into which is placed ore to a depth of several metres. The reactor is divided into sections. Intermittently, for 1-2 min, bacterial culture is pumped from below to fluidise one section of the bed. This practice uniformly wets and inoculates the ore, at the same time destroying any anoxic zones and washing out secondary precipitates or fines that might plug the bed. Air $\left(\mathrm{O}_{2}, \mathrm{CO}_{2}\right)$ is drawn down into the bed as the fluid drains between periods of fluidisation. Sequential fluidisation and draining of sections, together with controlled flow rate and solution management, achieved a degree of size separation and variation in residence time, as well as allowing the washing of the product solids in counter-current mode of operation.

The aerated trough reactor, developed for bio-assisted coal depyritisation [147,148] was a long, rectangular tank with $\mathrm{V}$-shaped base along which was a perforated pipe for air sparging. The trough was divided into sections with solid baffles each having a small hole at the slurry level for flow between sections. Each section had an independent aeration system and a drain for high-density solids removal (the pyrite-enriched fraction, subsequently the feed for the bacterial feed to the reactor).

Airlift reactors have been used relatively frequently for laboratory studies on bacterial leaching of soils, sediments and sludges $[149,150]$ but less frequently for bioleaching and metals extraction from ores or concentrates [151-155]. One of the reasons is that the rate of metal extraction decreases rapidly when the solids loading is greater than $20 \%$ [156], which, at the time, was one of the key improvements that was being sought in bioreactor design.

The rotating drum bioreactor (Biorotor) [157,158] is a baffled cylindrical barrel with an aeration inlet $\left(\mathrm{CO}_{2}\right.$ and $\left.\mathrm{O}_{2}\right)$ at one end and an air outlet at the other end. The cylinder sits on rollers and during rotation the baffles lift solids and then discharge them to fall through the solution, maximising mixing, eliminating "dead" zones and minimising shear stresses on bacterial cells. Tests carried out with $30 \%$ solids suspension of pyrite yielded solubilisation rates an order of magnitude greater than thought possible [158]. The rotating bioreactor has attracted recent attention with the development of a modified continuous reactor capable of processing a 40\% solids suspension [159].

Dumps, heaps, in situ and in stope leaching, vat leaching, and continuous stirred tank leaching are the main technologies applied commercially to the bio extraction of metals from minerals.

Dump, in-stope and in-situ leaching have been applied to copper [160,161] and uranium run-of-mine (ROM) ores [162,163]. Heap leach and bioleach technology for the extraction of $\mathrm{Cu}$ from oxidised ores and secondary copper sulfides have been applied most widely in Chile [164]. Heap or dump leaching of copper ores (Figure 3) has spread worldwide [165] and the technology has been adapted and applied to other commodities, for example gold [166], nickel [167], uranium [168] and zinc [169].

The Geocoat ${ }^{\mathbb{B}}$ technology is a means of treating concentrates with heap bioleach technology [170]. It combines the advantages of concentrating valuable metals into much smaller bulk and conducting the biooxidation/bioleaching unit process under heap leaching conditions, at lower cost than by stirred-tank processing. Most development tests for the Geocoat ${ }^{\circledR}$ process were conducted with a single target element, such as copper, gold or zinc [171-173]. In the case of refractory gold concentrates or platinum group element (PGE) extraction, the leached de-sulfidised residues would be washed off the support rocks and re-processed for the extraction of the metal. For base metals, soluble metals were recovered from the pregnant leach solutions (e.g., laboratory-scale tests for zinc and copper concentrates [174-176]). 

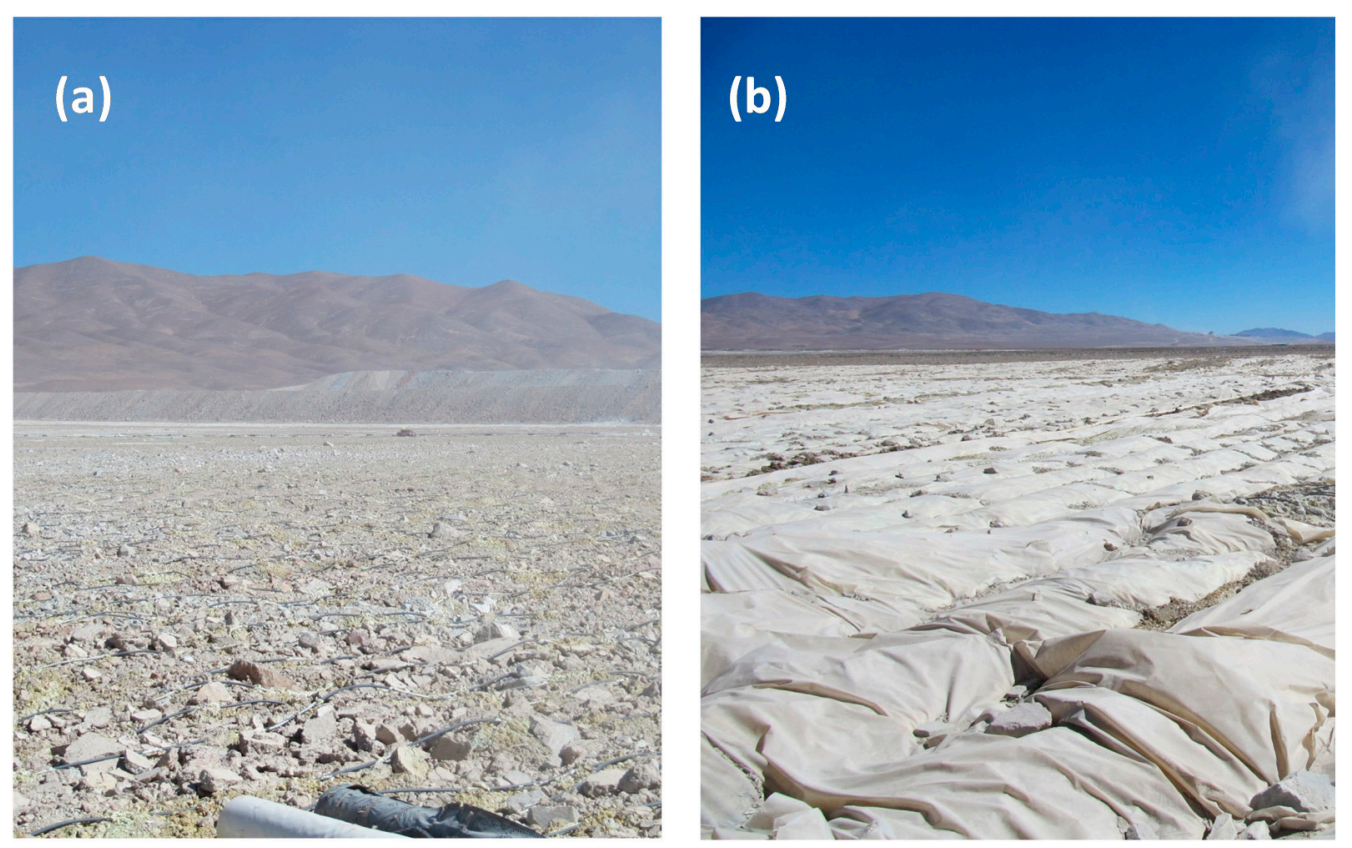

Figure 3. Run-of-mine dump bioleach at Escondida, Chile showing (a) surface with irrigation lines and (b) covers to retain heat and moisture. Photographs by D.W. Shiers, reproduced with permission.

The use of vat leaching for readily-leached oxidised ores has been largely superseded by dumps or heaps. Domic [164] described the introduction of vat leaching percolation (followed by direct electrowinning of copper) in 1915 at Chuquicamata and in 1928 at Potrerillos, and noted the first solvent extraction-electrowinning trials in Chile (1969-1970) using vat leach solutions from the Exótica (now Mina Sur) mine, and the commercialisation of Solvent extraction-electro winning (SX-EW) for the treatment of solutions from the vat leach of Mina Sur oxide ores in 1987. Currently, the only vat leaching operation for copper ore is located at Mantos Blancos mine in Chile (installed in 1961) (Figure 4). However, vat-leaching is well placed for a revival and wider application with the development of continuous vat technologies [177-179] within which conditions can be controlled and additives can be introduced to enhance extraction.

Agitated tank leaching was developed for the treatment of concentrates but has not found widespread commercial application except in the treatment of refractory gold ores [165,180,181]. Nevertheless, base-metals processes have been developed to pilot and demonstration scale for the bioleaching of copper (Figure 5), nickel and zinc sulfide concentrates using mesophiles, moderate thermophiles and thermophiles [128,182-186] and a process for the extraction of Co from pyrite concentrate has been commercialised [187].

A modification of the stirred tank technology is the separation of the leaching and metals recovery process from the biological regeneration of ferric ions; these are considered to be two-stage processes, termed "indirect bioleaching" or "effects separation" processes with which it is possible to optimise the leaching and biological processes independently and thus maximise metals recovery $[188,189]$. Another modification for the stirred tank technology is the operation of aerobic reactors followed by anaerobic reactors to effect acid leaching (air plus carbon dioxide sparge) and then bioreduction under anaerobic conditions (nitrogen plus carbon dioxide sparge) [190]. 


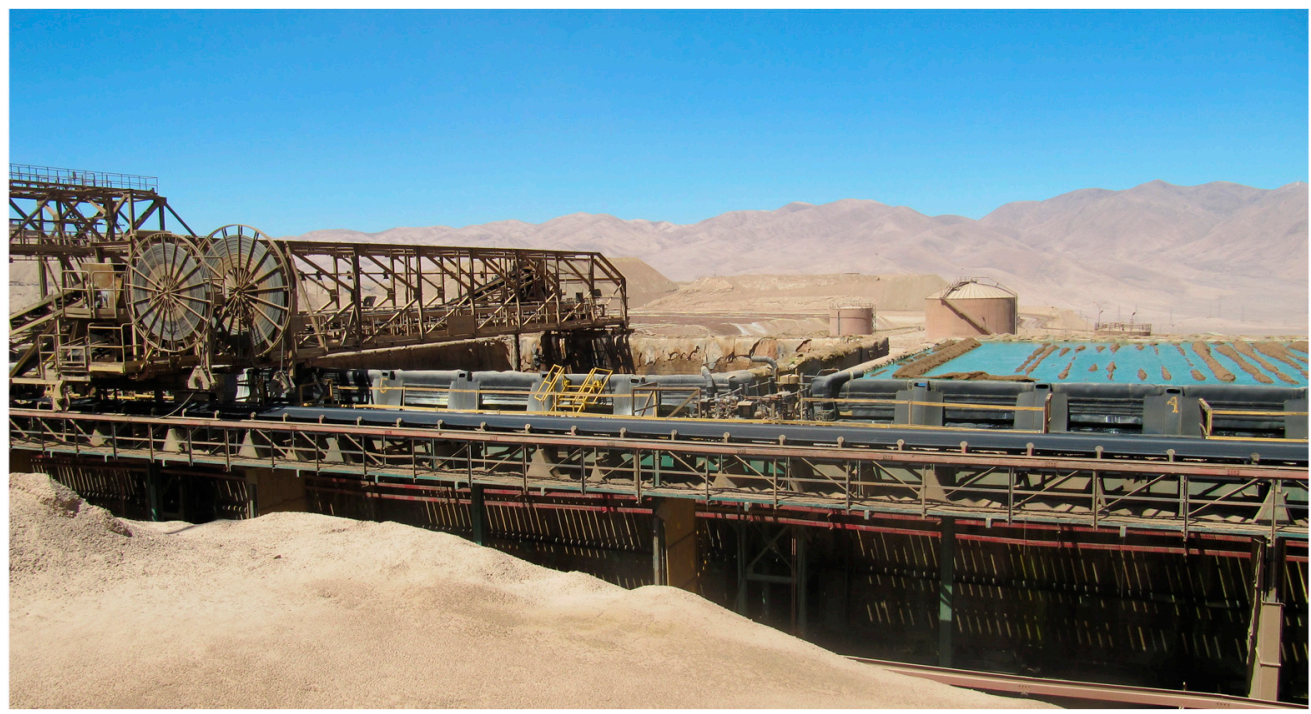

Figure 4. Vat leaching of oxidised copper ore at Mantos Blancos, Chile. Photograph by D.W. Shiers, reproduced with permission.

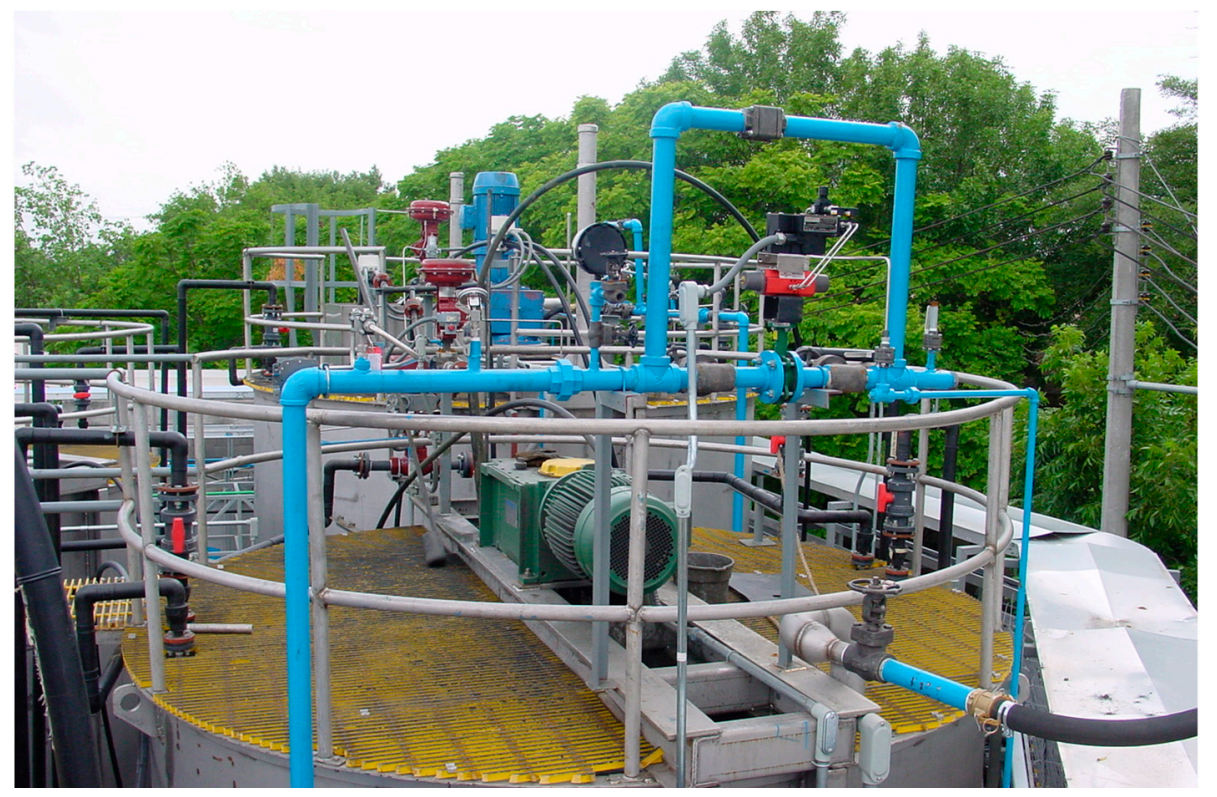

Figure 5. Bioleaching reactors at the Peñoles Mintek-Bactech demonstration plant at Monterrey, Mexico. Photograph by P.C. Miller, reproduced with permission.

Thus, in summary, the technologies required for the bio-processing of more complex, polymetallic ores and other materials have been developed, piloted and/or demonstrated. In addition, the advances briefly described above have been underpinned by concomitant progress in the separation and purification of many of the elements in the periodic table using solvent extraction or ion-exchange technologies [191-194]. Given the technology developments and the remarkable resilience and adaptability of acidophilic microorganisms, it is not surprising that numerous studies on the application of biohydrometallurgy to many different metal-rich materials from primary mineral resources, secondary mining products and numerous "manufactured" resources have been described. Subsequent discussion is therefore focused on compiling public-domain data on polymetallic bioleaching processes for the recovery or removal of metals from mineral resources, mine wastes and metalliferous 
sediments, for the purposes of either the production of metals or the remediation of contaminated mine sites.

\section{Polymetallic Sulfide Concentrates}

Studies using (nominally) pure mineral sulfide concentrates and well known biomining microorganisms as individual strains or prepared mixed cultures comprise the vast majority of fundamental investigations on bioleaching [195-198]. While describing the extraction of only one element, these studies instil confidence that microorganisms are capable of enhancing the extraction of many elements that occur as, or are associated with, sulfide minerals.

The much smaller body of literature on the bioleaching of polymetallic concentrates are, for the most part, conducted at laboratory scale with only a few being developed to pilot scale and integrated with down-stream purification and separation of the precipitates or metallic products. In most laboratory studies, the bioleaching of sulfide minerals or elements associated with them was investigated using known species of iron(II)- and sulfur-oxidising microorganisms in reactors operated at $\mathrm{pH} 1.5-2$ and temperatures in the range of $25-55^{\circ} \mathrm{C}$; the extractions of elements known to leach readily $(\mathrm{Cu}, \mathrm{Zn}, \mathrm{Ni}, \mathrm{Co}$, As) were reported [199-204]. The extractions of more refractory metals not necessarily associated with sulfide minerals such as Mo, Re, V and U were reported in only a few studies $[205,206]$.

Among the studies using polymetallic concentrates are examples of:

- direct bioleaching in continuous stirred tanks [182,207-209],

- two-stage indirect bioleaching, in which ferric ion oxidation of sulfides and ferric ion regeneration by microorganisms are effected in separately optimised bioreactors [137,210-212], and

- combinations of bioleaching and chemical leaching [213,214].

The purposes of the studies varied but included:

- extraction of metals;

- removal of unwanted contaminating elements from "dirty" concentrates [215-218];

- stabilisation and/or immobilisation of unwanted waste products, facilitating residue storage, disposal or subsequent treatment [214,219-221]; or

- descriptions of the microorganisms involved at various stages of processing [222-226].

In some studies, methods for the separation and recovery of a variety of metal products were either tested or suggested in proposed flow sheets. Solvent extraction-electro winning (SX-EW) comprises a well developed suite of technologies applied to most hydrometallurgical processes in which base metals are to be recovered from solution and, as such, does not receive particular attention in the examples cited. However, intermediate products like hydroxide or sulfide precipitates or cementation are also possible. In a number of studies note was made that precious metals reporting to the leached residues could be recovered using cyanide or more aggressive reagents [176,213,214,219,227].

One of the research streams in the Bioshale FP6 project [228] was directed towards process developments for the copper- and silver-enriched black shale ore and concentrate from Lubin mine and concentrator, Poland. The copper concentrator also produced a middling shale fraction that had similar properties to the shale ore but caused problems in the flotation plant. The team showed that both 
the concentrate and the middlings could be leached using acidophilic iron(II)- and sulfur-oxidising microorganisms in a range of temperatures from 30 to $78^{\circ} \mathrm{C}$ [213,229-231]. However, in respect of the tank bioleaching tests [213] it was concluded that the grades for nickel, copper and zinc in the concentrate were too low for this process option to be economic.

\section{Low Grade Sulfide Ores}

Low-grade sulfide ores are those from which it is not economical to prepare a concentrate, or those of complex mineralogy that precludes upgrading by gravity or flotation concentration processes. Being of low grade, economic processing necessitates the application of low-cost technology. Currently, the technologies of choice are heap or dump leaching, both of which have been commercialised on very large scales for the leaching of copper sulfide ores [30,164] but historically, in situ and in stope bioleaching have received considerable attention for the extraction of copper [232,233] and uranium [162,234]. Investigations of the amenabilities of different ores generally involve laboratory-scale test work, small-medium or large-scale columns or cribs to simulate the heap environment, and larger test heaps. It is not surprising, therefore, that many laboratory-scale studies using pulverised ore are reported as part of the preliminary assessment of different ores and the growth of microorganisms, and that far fewer studies address the larger-scale issues. For the purposes of this review, low-grade sulfide ore types have been grouped as "low" organic carbon content and "high" organic carbon content.

\subsection{Ores with Low Organic Content}

There are relatively few studies of the extraction of more than one element from low-grade, low organic-carbon-content ores using bioleaching and most studies have been focused on copper or nickel. Typical of many ore bioleaching studies, Groudeva and Groudev [235] applied a mixed culture of the then-known iron(II)-oxidising, sulfur-oxidising bacteria and heterotrophic bacteria to the extraction of copper and zinc from a pyritic ore that contained chalcopyrite, sphalerite and galena. A depth profile of bacterial presence and activity was obtained from the $2 \mathrm{~m}$ columns. In that study, cell numbers, iron(II) oxidation and carbon dioxide fixation decreased with depth and the amounts of copper and zinc extracted after 300 days also decreased with depth. Maximum extraction of both metals in the top section of the column was $91 \%-92 \%$.

Marine hydrothermal polymetallic sulfide materials may contain high concentrations of $\mathrm{Cu}, \mathrm{Pb}, \mathrm{Zn}$, $\mathrm{Au}, \mathrm{Ag}, \mathrm{In}, \mathrm{Ge}, \mathrm{Bi}$ and Se, and are more like polymetallic concentrates than ores. For example, the test material used by Korehi and Schippers [236] was mainly composed of chalcopyrite $(38.5 \% \mathrm{Cu})$. Copper was monitored during bioleaching at three temperatures using known biomining microorganisms. Extractions correlated with temperature, 56\%, 42\% and 32\% after 28 days at 70, 50 and $30^{\circ} \mathrm{C}$, respectively.

The unprecedented rise in the price of nickel in the period up to 2006 together with encouraging results from bench-scale testwork prompted pilot- and demonstration-scale trials of nickel sulfide ores in heaps and agitated tanks in Australia, Finland, China and South Africa [237-240]. Watling et al. [241] undertook retrospective studies aimed at understanding the nickel and copper leaching chemistry in a copper-nickel test heap in Western Australia [237]. In that heap, 91\% Ni was recovered in one year but copper extraction lagged behind (50\% recovery). Examination of leached heap and column materials 
showed that chalcopyrite had been oxidised and the copper mobilised, but that copper had precipitated from solution as covellite or possibly chalcopyrite at greater depth in the heap or column and only subsequently redissolved when the solution chemistry changed [242-244].

Another extensive study of the bioleaching of nickel sulfide in a pentlandite-pyrrhotite ore was conducted under conditions selected to minimise magnesium solubilisation $(\mathrm{pH}>3)$ from $\mathrm{Mg}$-rich silicate minerals while maintaining efficient nickel extraction [245-247]. Subsequently, the bioleaching of six Ni-Co-Cu-containing ores from different geographical regions were compared using stirred tanks and solutions of $\mathrm{pH} 2-5$ [248]. The results indicated that, by lowering the solution acidity from $\mathrm{pH} 2$ to $\mathrm{pH} 3$, nickel and cobalt extractions were the same within statistical error but acid consumption by the gangue minerals was significantly reduced. As a pre-inoculation strategy, a test heap of high-magnesium $\mathrm{Ni}-\mathrm{Co}-\mathrm{Cu}$ sulfide ore was leached for 80 days with dilute acid to remove the readily leached magnesium [249]. This strategy, while not minimising overall acid consumption, did generate conditions conducive to microbial activity throughout the ore bed with the result that $84.6 \% \mathrm{Ni}$ and $75 \%$ Co was extracted after 350 days.

In addition to "standard" testwork, research topics of strong interest included:

- $\quad$ in-situ or in-stope bioleaching [250-255];

- $\quad$ strategies to deal with gangue mineral acid consumption while maintaining conditions conducive to microbial growth [245-248,256];

- comparisons of different reactor designs or modes of operation [250,257-259]; and

- development of hybrid processes in which the base metals were bioleached and precious metals or lead were extracted subsequently from the leached residues in a secondary process [235,260-262].

As far as is known, none of the above studies resulted in commercial developments, although flowsheets were described for two of the proposed processes [261,263].

\subsection{Sulfidic Schists and Shales with High Organic Content}

The main driver for the development of technologies to extract metals from black shales and schists is the uranium content. It is estimated that the black shales around the Black Sea collectively contain the largest known uranium resource in the European Union [264]. However, in general, black shales occur in many parts of the world and contain many base and precious metals (Table 1). Estimated averages for trace element contents in black shales and coals have been collated [265]. The elements V, Mn, Co, Ni, Cu, Zn, Y, Zr, Mo, Ag, Cd, Ce, Re, Au, Hg, Th and U, were identified as target metals for possible production from black shales. $\mathrm{V}, \mathrm{Ni}, \mathrm{Mo}$, Re and $\mathrm{U}$ dominate the more-difficult-to-extract porphyry-bound metals in shales but $\mathrm{Cu}, \mathrm{Fe}, \mathrm{Se}, \mathrm{Ag}, \mathrm{Cd}$ and $\mathrm{Bi}$ typically occur as discrete mineral phases.

\subsubsection{Microbiological Aspects}

Fundamental multi-element laboratory-scale studies were conducted on shales from a variety of regions. The studies fall into two groups, those that employed autotrophic iron(II)- and sulfur-oxidising acidophiles and those that employed organic-acid-producing heterotrophs. As was the case with the bioleaching studies on low-carbon complex sulfide ores (Section 4.1), many of the laboratory studies 
on black shales and schists provided valuable data on the different ore types and the kinetics and extent of metals extraction from them under varied but controlled conditions. More than one element was monitored in most studies, mainly those elements that occurred as discrete mineral sulfides and the associated precious metals, because technologies are available for their recovery (Section 2.4).

Bioleaching with autotrophic acidophiles presupposes that the target material will supply the required iron(II) and reduced inorganic sulfur species to support microbial growth [266,267] or that these substrates can be added economically [268-270]. Many metalliferous black shales and schists contain discrete pyrite grains within the organic matrix, thus meeting that particular requirement [87,266,267,271,272] (Figure 6). In two studies on the Alum shale ore, bioleaching was undertaken in tanks or columns inoculated with mixed mesophilic and moderately thermophilic cultures enriched from acidic pools at an auto-heating coal mine [266,267]. For the tank bioleaching of ground ore, maximum extractions after $28-30$ days at $55^{\circ} \mathrm{C}$ were for $\mathrm{Cu}(72 \%-80 \%)$, Zn (96\%-97\%), $\mathrm{Ni}(46 \%-50 \%)$ and $\mathrm{Co}(82 \%-83 \%)$. For the columns using $-25 \mathrm{~mm}$ crushed quarter drill core, maximum extractions at $50{ }^{\circ} \mathrm{C}$ and $\mathrm{pH} 1.6$, were $\mathrm{Co}(>90 \%)$, $\mathrm{Ni}$ and $\mathrm{Cu}(65 \%)$ and $\mathrm{Zn}(70 \%)$, after 102 days. Acid consumption was lower than anticipated from the shale carbonate content.

Table 1. Some base metal districts with black shale and schist deposits potentially suited to bioleaching [86,87,272-279].

\begin{tabular}{|c|c|}
\hline Deposit/Region & Enriched Elements \\
\hline Talvivaara, Finland & $\mathrm{Ni}, \mathrm{Cu}, \mathrm{Co}, \mathrm{Zn}, \mathrm{Mn}, \mathrm{U}, \mathrm{Ag}, \mathrm{As}$ \\
\hline Kainuu, Finland & $\mathrm{Ni}, \mathrm{Cu}, \mathrm{Co}, \mathrm{Zn}, \mathrm{V}, \mathrm{Mo}$ \\
\hline Alum shale, Sweden & $\mathrm{Ni}, \mathrm{Cu}, \mathrm{Co}, \mathrm{Zn}, \mathrm{Pb}, \mathrm{V}, \mathrm{Mo}, \mathrm{U}, \mathrm{Cr}, \mathrm{Mn}, \mathrm{Ba}$ \\
\hline Viken, Sweden & Ni, V, Mo, U \\
\hline Kupferschiefer, Poland & $\mathrm{Cu}, \mathrm{Ag}, \mathrm{Zn}, \mathrm{Ni}, \mathrm{Co}, \mathrm{Pb}, \mathrm{Mo}, \mathrm{V}, \mathrm{U}, \mathrm{As}, \mathrm{Se}, \mathrm{Cd}, \mathrm{Bi}, \mathrm{Tl}, \mathrm{Re}, \mathrm{PGE}$ \\
\hline Kamenec, Czech Republic & $\mathrm{Ni}, \mathrm{Cu}, \mathrm{Zn}, \mathrm{Mo}, \mathrm{Cr}, \mathrm{PGE}$ \\
\hline Hromnice, Czech Republic & $\mathrm{Ni}, \mathrm{Cu}, \mathrm{Zn}, \mathrm{V}, \mathrm{Mo}, \mathrm{Au}$ \\
\hline Pyrenées, France & $\mathrm{Zn}, \mathrm{Pb}, \mathrm{P}, \mathrm{Ge}, \mathrm{Cd}$ \\
\hline Eastern Pyrenées, France & $\mathrm{Ni}, \mathrm{Cu}, \mathrm{Co}, \mathrm{Zn}, \mathrm{Pb}, \mathrm{Au}, \mathrm{W}, \mathrm{Sb}$ \\
\hline Dauphiné Basin, France & $\mathrm{Ni}, \mathrm{Cu}, \mathrm{Pb}, \mathrm{U}, \mathrm{Ba}$ \\
\hline Selwyn Basin, YT, Canada & $\mathrm{Ni}, \mathrm{Zn}, \mathrm{Pb}, \mathrm{Mo}, \mathrm{Ag}, \mathrm{Cd}, \mathrm{In}, \mathrm{Sb}, \mathrm{Se}, \mathrm{As}, \mathrm{Au}, \mathrm{Tl}, \mathrm{Re}, \mathrm{PGE}$ \\
\hline Athabaska region, $\mathrm{AB}$, Canada & $\mathrm{Ni}, \mathrm{Cu}, \mathrm{Co}, \mathrm{Zn}, \mathrm{V}, \mathrm{Mo}, \mathrm{U}, \mathrm{Ag}, \mathrm{Au}, \mathrm{Li}, \mathrm{Cd}, \mathrm{REE}$ \\
\hline Kimberley, BC, Canada & $\mathrm{Cu}, \mathrm{Zn}, \mathrm{Pb}, \mathrm{Sn}, \mathrm{Ag}, \mathrm{Sb}, \mathrm{Cd}, \mathrm{Bi}$ \\
\hline Red Dog, AK, USA & $\mathrm{Zn}, \mathrm{Pb}, \mathrm{Ag}, \mathrm{Se}, \mathrm{Ba}$ \\
\hline Carlin region, NV, USA & $\mathrm{Ni}, \mathrm{Zn}, \mathrm{V}, \mathrm{Mo}, \mathrm{Se}, \mathrm{Au}, \mathrm{Ag}$, As \\
\hline Mina Aguilar, Argentina & $\mathrm{Zn}, \mathrm{Pb}, \mathrm{Ag}$ \\
\hline Rajasthan, India & $\mathrm{Zn}, \mathrm{Pb}, \mathrm{Ag}$ \\
\hline KPK Region, Pakistan & $\mathrm{Cu}, \mathrm{Zn}, \mathrm{V}, \mathrm{Mn}, \mathrm{U}, \mathrm{Ti}$ \\
\hline Zunyi, China & Ni, Zn, Mo, Au, Se, As, PGE \\
\hline Changba, China & $\mathrm{Zn}, \mathrm{Pb}$ \\
\hline Western Yunnan, China & $\mathrm{Cu}, \mathrm{Zn}, \mathrm{Pb}, \mathrm{Tl}, \mathrm{Cd}, \mathrm{Ag}, \mathrm{As}$ \\
\hline Okcheon, South Korea & $\mathrm{Ni}, \mathrm{Cu}, \mathrm{Zn}, \mathrm{V}, \mathrm{Mo}, \mathrm{U}, \mathrm{Ba}, \mathrm{Cr}, \mathrm{Y}, \mathrm{Au}, \mathrm{PGE}$ \\
\hline Mt Isa, Australia & $\mathrm{Zn}, \mathrm{Pb}, \mathrm{Ag}$ \\
\hline Gauteng, RSA & $\mathrm{Ni}, \mathrm{Cu}, \mathrm{Co}, \mathrm{Zn}, \mathrm{Pb}, \mathrm{V}, \mathrm{Mo}, \mathrm{Cr}, \mathrm{Au}$ \\
\hline Konkola, Zambia & $\mathrm{Cu}, \mathrm{Co}, \mathrm{U}, \mathrm{Pd}, \mathrm{Re}$ \\
\hline
\end{tabular}




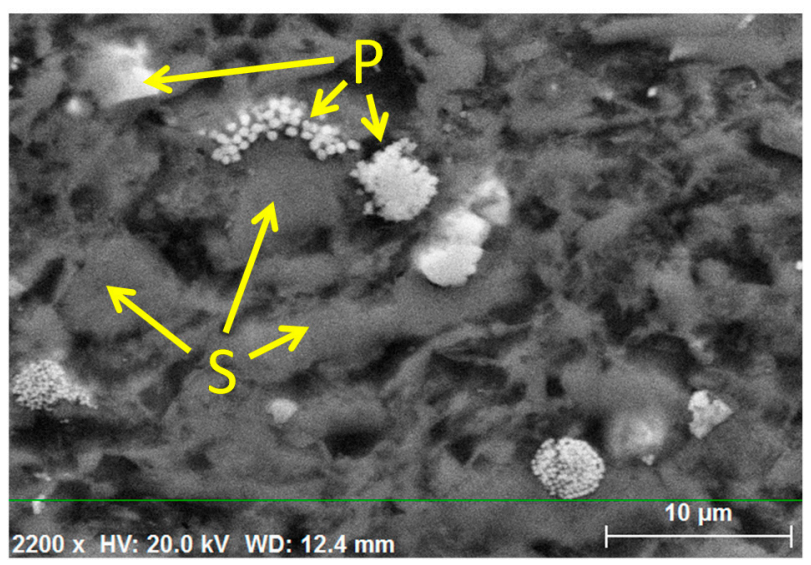

Figure 6. SEM visualization of a polished block of Alum shale from Sweden showing silicate minerals $(\mathrm{S})$ and pyrite $(\mathrm{P})$ embedded within the porous organic matrix.

In another study [280], columns containing polymetallic sulfide black-schist ore high in pyrrhotite were inoculated with a mixed moderately thermophilic culture or thermophilic microorganisms and operated at $47{ }^{\circ} \mathrm{C}$ or $68{ }^{\circ} \mathrm{C}$, respectively, for approximately a year. Maximum extractions in inoculated columns were $39 \%, 34 \%, 17 \%, 19 \%$ at $47{ }^{\circ} \mathrm{C}$ and $69 \%, 64 \%, 11 \%$ and $32 \%$ at $68{ }^{\circ} \mathrm{C}$ for $\mathrm{Ni}, \mathrm{Zn}, \mathrm{Cu}$ and $\mathrm{Co}$, respectively. An interesting feature of the tests was the repacking of columns mid-way through the leach, which resulted in an immediate but short-lived increase in the extraction rates of metals in the $47{ }^{\circ} \mathrm{C}$ columns. The enhanced extraction rates were of longer duration in the $68{ }^{\circ} \mathrm{C}$ columns and were attributed to the disturbance of well-established solution channels and resultant effective contact of the lixiviant with fresh ore particles after column repacking. The possibility that insoluble iron(III) compounds deposited on particle surfaces during percolation leaching of the black schist ore could be removed was tested using At. ferrooxidans or $S$. thermosulfidooxidans during autotrophic growth on sulfur under anaerobic conditions [281]. A strategy of alternating periods of aeration and anoxic conditions during leaching resulted in much greater nickel, copper and zinc extraction.

Among those studies in which biogenic organic acids were utilised, key parameters were (i) the variety of microorganisms that could be exploited; (ii) the predominant acids produced by them and (iii) the best carbon sources to be used should larger scale bioleaching reactors be commissioned.

Heterotrophic bacteria, Pm. fluorescens, Shewanella (Sh.) putrefaciens and Pm. stutzeri, were applied to the extraction of uranium from shale tailings at the Ranstad uranium mine, Germany (now closed) [282]. The focus of that study was on metals mobilisation from the tailings rather than economic metals extraction, and the species selected for the tests were known ligand-producing bacteria. The authors noted that ligands may increase the mobility of micronutrients such as $\mathrm{Cr}, \mathrm{Co}$, $\mathrm{Cu}, \mathrm{Mn}, \mathrm{Fe}, \mathrm{Mo}, \mathrm{Ni}, \mathrm{V}$ or $\mathrm{Zn}$ and possibly lanthanide and actinide elements at $\mathrm{pH} \sim 7$. Bacteria isolated from the black shale included strains of Pseudomonas, Acinetobacter, Bacillus and Microbacterium spp. All were able to grow in salts medium containing black shale as sole energy and carbon source.

Among the heterotrophic fungi that have been applied to uranium and/or metals extraction from black shales are Aspergillus (A.) niger, Penicillium (Pc.) notatum, Ganoderma (G.) lucidum or native strains of A. flavus, Curvularia clavata and Cladosporium oxysporum [283-287]. Fungal leaching is generally slower than bacterial leaching. For example, native fungal strains supplied with sucrose mobilised up to $71 \% \mathrm{U}$ in 10 days [283], compared with $80 \%$ extraction using At. ferrooxidans 
supplied with ferrous ions [268]. However, based on their own results, Anjum et al. [269,285,288,289] concluded that fungi may be a better choice when the polymetallic ore (concentrate or tailings) has high organic-carbon content.

When leaching with heterotrophs, questions arise about what organic carbon source must be supplied for maximum growth and organic acid production, which acids are most effective for the target metals, and whether the supply of an organic carbon source is economic for a proposed process. The studies by Anjum, Bhatti and co-workers [285-288] go some way to providing answers in respect of shale ores. In chemical leaching tests using black shale, citric acid was most efficient for copper extraction, oxalic acid for zinc and cobalt extractions and tartaric acid was the least effective for the three metals [288]. In similar tests using brown shale (shale formed in an oxidising environment), citric acid was best for copper, manganese and aluminium extractions and tartaric acid was also effective for copper, but oxalic acid was the most effective for magnesium extraction from brown shale [287].

While four organic acids, citric, oxalic, tartaric and malic acids, were detected in bioleaching solutions from tests on black shale using $A$. niger provided with different substrates, citric acid was the main acid produced [285]. In the case of Pc. notatum, the same four acids were detected but the substrate influenced dominant acid production. With glucose, Pc. notatum produced citric acid and $\mathrm{Cu}$ and $\mathrm{Mg}$ were preferentially extracted $(>80 \%)$, but with molasses as substrate, tartaric acid was produced and $\mathrm{Mn}$ and $\mathrm{Cu}$ were extracted (>70\%) [286]. G. lucidum produced up to 10 times more tartaric acid than the other acids [287].

The substrates typically used in laboratory bioleaching tests are refined organic carbon compounds that would be prohibitively expensive for commercial-scale plants. Thus, the use of less expensive materials has been trialled. In a comparison between glucose, molasses or breadcrumbs as sources of carbon, it was reported that $P c$. notatum produced very little acid from the breadcrumbs [286]. When glucose, molasses, sawdust or cottonseed cake were compared, acid production by G. lucidum (mainly tartaric acid) was low from either sawdust or cottonseed cake [287]. In addition to glucose and molasses, the alternative substrates tested by Anjum et al. [285] were mango peel, seedcake and rice bran. Citric and malic acids, the two main acids produced by A. niger, decreased in concentration in bioleaching solutions in the order mango peel $>$ seedcake $>$ rice bran but maximum biomass production was obtained using acidified mango peel as the organic carbon source (compared with glucose and molasses). Sjoberg et al. [290] also focused on the cost of refined organic carbon compounds. They selected aspen wood shavings in a low-water-content system. In that study, overall extraction was very low (1.7\% U in 56 days) but the authors showed that the minimum effort and cost process could mobilise uranium from shale.

\subsubsection{Prospects for Commercialisation}

It is not surprising that black shales have been studied extensively with a view to multi-metal extraction and some deposits are being considered for commercialisation. A key parameter in the decision-making process is the size of the deposit because the concentrations of the target elements tend to be low. Jowitt and Keays [276] reported that there had been significant research in three of the shale-hosted nickel regions, either because of their size or because of the high metal grades; they are the Talvivaara deposit in Finland, a number of nickel-molybdenum deposits in southern China 
(e.g., Zunyi and Zhijin, Guizhou province; Dayong and Cili, Hunan, Dexhe, Yunnan, Duchang, Jiangxi and Lizhe, Zhejiang [291]), and deposits in the Selwyn Basin, Yukon, Canada. Copper-enriched polymetallic black-shale ores and their concentrates have been a focus of two large, international projects supported by the European Union, the BioMinE project [292] and the BioShale FP6 project [228]. It should be noted that, while grades or deposit size might preclude the development of economic processes for today's industry, smaller, lower-grade deposits might become economic in the future [276], particularly in view of the success of the Talvivaara heap bioleaching process [238] and the pilot-scale studies on Kupferschiefer concentrates and ores [228].

The considerable body of research on Finnish ore deposits dates back more than 25 years but the main deposit of interest in the context of bioleaching is that at Talvivaara. The Talvivaara ore body is a large black schist deposit (>400 Mt) containing disseminated sulfide minerals, pyrrhotite $(\sim 15 \%)$, pentlandite/violarite, sphalerite, chalcopyrite and alabandite, and carbon as graphite $(\sim 10 \%)$ [293].

Initial studies involved batch bioleaching tests in which copper, zinc, nickel and cobalt extractions were monitored, bioleaching conditions were optimised, and the effects of temperature, $\mathrm{pH}$ and oxidation-reduction potential (ORP) on extraction were examined [229,294,295]. In column leaching studies, a microbial culture enriched from mine water was active over a wide temperature range in bench scale columns, different microbial populations evolved at different temperatures, and $\mathrm{pH} 2$ was optimal for nickel, zinc and cobalt extractions [296,297], but copper extraction was minimal in the time frame of the experiment. The benefit of supplementing bioleaching tests inoculated with an iron(II)- and sulfur-oxidising mixed culture with additional ferrous ions was tested and the altered mineralogy that evolved during bioleaching investigated [298-300].

Two major studies were undertaken as part of the Bioshale FP6 European project, specifically, a pilot-scale column bioleaching trial on agglomerated ore [301] and a tank bioleaching trial using flotation concentrate [213] (see Section 3). Complementary laboratory-scale experimental and theoretical studies included the application of bioflotation to increase the amount of concentrate obtainable and/or its grade, and modelling - simulation of heat transfer in heap bioleaching using data from both the pilot crib operated by the Geological Survey of Finland and the pilot heap conducted at Talvivaara mine [228].

The large-scale column tests [301] comprised two columns charged with ore of different particle size ranges. In addition to metal-extraction kinetics, the evolution of the microbial community was monitored as a function of time. Similarly, Halinen et al. [302] monitored microbial community diversity in the demonstration heaps at the Talvivaara mine site, showing that microbial diversity decreased with time and differing community profiles evolved with changes in temperature and location in the heap. From these column and heap studies it was jointly concluded that heterogeneity in heaps (depth, temperature, acidity, changes induced during leaching) will favour different suites of microorganisms and that overall efficient metal extraction depends on the presence of a sufficient diversity of microorganisms.

Together, these multi-element studies contributed directly and indirectly to the commercialisation of the Talvivaara heap bioleaching project [238]. As a result, interest in developing Scandinavian ore bodies in the Outokumpu region, the Viken and Storsjon deposits, Alberta Canada and other regions has increased markedly [272,273,275,303-305]. 
While large areas of the Kupferschiefer black shale contain only average concentrations of base and precious metals, some deposits are enriched to ore grades and often exceed $4 \mathrm{wt} \% \mathrm{Cu}$, mainly as chalcocite, bornite and chalcopyrite enriched with silver. In the Mansfeld district (Germany), near-surface zones were exploited for silver and copper from mediaeval times. Pyrite (enriched with nickel and cobalt), marcasite, galena (enriched with silver), sphalerite and native Ag occur with the black shale deposits and many other elements in the Kupferschiefer shale were reported (Table 1) [87,306].

The body of research within the BioShale FP6 European project on processing of the "Kupferschiefer" black shale follows the historical trend of focusing on copper and silver extraction [153,307-309] but with broad research objectives [228]: to assess bioprocessing methods and complementary processing routes for hydrometallurgical recovery of metals, undertake a risk assessment regarding waste management and a techno-economic evaluation of new processes, and to characterise microbial communities engaged in leaching.

In direct bioleaching tests in stirred, aerated $4 \mathrm{~L}$ reactors inoculated with Acidithiobacillus strains, up to $65 \% \mathrm{Cu}$ was extracted in 28 days $\left(\mathrm{pH} 2,40{ }^{\circ} \mathrm{C}\right)$, but there was a lag before nickel extraction rose to $65 \%$, and zinc extraction was poor (6.5\%) [310]. The absence of lead in solutions was attributed to the oxidation of galena followed by the precipitation of $\mathrm{PbSO}_{4}$ in the residues. When indigenous Bacillus strains were used to inoculate flasks or $4 \mathrm{~L}$ tanks containing shale ore there was an initial increase in metals (dissolution of soluble components), a lag period before extraction commenced and low extractions in 28 days (for $T=40{ }^{\circ} \mathrm{C} ; 3 \% \mathrm{Cu}, 10 \% \mathrm{Ni}$ and $<0.1 \% \mathrm{Zn}$ ) [90]. It was concluded that nickel, and to a lesser extent copper and zinc, were bound as organo-metallic compounds in the shale [90].

Two two-stage bioleaching investigations were conducted. In the first, carbonaceous black shale ore (22 wt \% inorganic carbon) was pre-leached with sulfuric acid before the columns were inoculated with mixed mesophilic iron(II)- and sulfur-oxidising acidophiles and irrigated with ferric ion-rich acidic medium [309]. Copper (82\%) was recovered from leach solutions using cementation with metallic iron, and silver (51\%) was recovered from the leached, neutralised residues using ammonium thiosulfate ( $\mathrm{pH} 10)$ and subsequently recovered by cementation using $\mathrm{Zn}$. This process was deemed not to be economic because of reagent consumption (ammonium thiosulfate, copper sulfate, and zinc).

In the second two-stage process [308], heterotrophic bacteria isolated from flotation waste [91] were used to inoculate flasks containing medium $\left(\mathrm{pH} \mathrm{7,30}{ }^{\circ} \mathrm{C}\right)$ and ore. The underlying premise of this research was that heterotrophic microorganisms should enhance the degradation of the organic fraction of the ore and thus release bound metals. However, only $1 \% \mathrm{Cu}$ and $6 \% \mathrm{Ag}$ were extracted during the first stage of bioleaching using heterotrophs. After 25 days, the treated residues were separated and dried, resuspended in sulfuric acid medium ( $\left.\mathrm{pH} 1.8, T=25^{\circ} \mathrm{C}\right)$ and inoculated with Acidithiobacillus strains to oxidise sulfide minerals. At the end of the second stage (60 days of bioleaching), $72 \% \mathrm{Cu}$ was extracted but only $9 \% \mathrm{Ag}$. In 35 -day tests using the autotrophs, extractions were $41 \% \mathrm{Cu}$ and $11 \% \mathrm{Ag}$. However it is unclear to what extent the increased extraction of copper in the two-stage process was due to the extended period of leaching or how much might be attributed to the effects of the heterotrophs, for example on mineral surfaces, given they would not be expected to function during the acidic bioleach. Overall, these results do not present convincing evidence of the benefit of a two-stage process.

The research undertaken in the BioShale project and reported extensively, finds a natural extension within the newly-funded BioMOre project, an objective of which is "to extract metal from deep 
mineralised zone in Europe (Poland and Germany) by coupling solution mining and bioleaching technologies". This project will build on the knowledge from both the BioShale FP6 project, that copper and other metals can be efficiently extracted from black shale "Kupferschiefer" deposits, and the EU-funded ProMine Fp7 project, within which it was demonstrated that huge potential reserves in copper and other metals occur at depths greater than $1500 \mathrm{~m}$ in Central Europe [311]. One of the proposed research topics is the application of biotechnology to in-stope leaching of polymetallic black shale at the Lubin mine, Poland. Research into in situ or in stope bioleaching is an important part of the future for mineral processing, even although deposits with the physical and geological requisites may be rare. Underground technologies are perceived as better for the environment (the "invisible mine") and likely to attract community acceptance, and may also be the means of accessing deposits too deep for current economic mining technology. Therefore research to advance any part of the many aspects of successful technology development is to be welcomed.

\section{Oxidised Ores}

While oxidised ores may contain more than one element of interest, they are not generally considered to be polymetallic and mineral processing operations are often focused on the production of a single element and seldom produce more than two elements. However, that may change as global resources of different elements become diminished.

Metals extraction from oxidised ores using biotechnologies have not been commercialised to date but have been developed to laboratory and pilot scale. Most process developments are chemical rather than biochemical, as evidenced by the numbers of publications found in literature searches using the terms: "laterite AND leach*" (766) against "laterite AND bioleach" (40), "manganese dioxide" AND leach*" (576) against "manganese dioxide AND bioleach*" (15), or "copper silicate AND leach" (7) against "copper silicate AND bioleach" (1). As a further example, in a recent review [312], commercial processes and prospective processes for nickel laterites were described and critically assessed; none of them utilised microorganisms. Similarly, in a review of manganese metallurgy [313], pyrometallurgy and hydrometallurgy (chemical leaching) technologies dominated the discussion. Nevertheless, methods that target the bioleaching of manganese nodules and nickel laterites are topics that continue to inspire the development of novel biotechnologies.

Manganese is the twelfth most abundant element in the earth's crust [314]. Pyrolusite $\left(\mathrm{MnO}_{2}\right)$ is the most common manganese mineral but manganese also occurs in carbonate and silicate minerals. Manganeses nodules or polymetallic nodules are rock concretions formed of iron and manganese hydroxides around a core and often contain nickel, cobalt and copper. Nodules of economic interest occur in the north central Pacific Ocean, the Peru Basin in the south east Pacific, and the central north Indian Ocean. The existence of many microorganisms with enzymes capable of oxidising or reducing manganese has been reported [314].

In the future, nickel production from lateritic ores is expected to far exceed that from sulfides because laterites comprise about $70 \%$ of land-based nickel reserves [315]. Most of the bioleaching studies on laterites relate to bodies of research on Greek laterites that contain nickel, cobalt and chromium [32,76,316-318], Indian laterites that contain nickel, cobalt and chromium [319-323], New Caledonian laterites that contain nickel, cobalt and manganese [33,324-330] and African laterites that 
contain nickel, cobalt, manganese and chromium [77,331,332]. In metal extraction, the key difference between copper oxide or sulfide ores and nickel laterite ores is the absence of specific nickel phases in the lateritic ores [333]. As a consequence, in order to extract the nickel, it is necessary to dissolve or alter the host phases, which are mainly silicates and iron oxides. Interest in the application of one or more biotechnologies to the extraction of nickel (and other elements) from laterites has a long history, including some innovative process suggestions, but few have reached pilot stage.

Tested biotechnologies for oxidised ores fall into three groups, those that use: (i) inorganic acid generated by the biooxidation of RISCs; (ii) organic acid generated by heterotrophic metabolism of organic compounds; or (iii) a combination of bioreduction and leaching. Some examples are described for each of the modes, where possible using studies in which more than one element was extracted.

\subsection{Leaching with Acidophilic Autotrophs/Inorganic Acid}

The use of inorganic acids to dissolve oxidised ores such as manganese oxides or nickel laterites, comprising silicate and iron oxide minerals, is well known. The use of autotrophic sulfur oxidising microorganisms is a means of minimising costs because elemental sulfur is generally a less expensive commodity than sulfuric acid. Thus, in its simplest form, autotrophs such as At. ferrooxidans and At. thiooxidans and more recently discovered sulfur oxidising species oxidise elemental sulfur and the biogenic acid dissolves the manganese dioxide or laterite minerals.

Using this basic system of acid bioleaching to extract manganese from manganese dioxide, Imai [334] noted that the microorganisms contributed more than just acid, as extractions of manganese were higher in the presence of microorganisms than with chemical acid leaching. It was postulated that intermediate reduced sulfur species, such as hydrogen sulfide or sulfite produced during the biooxidation of sulfur, accelerated the dissolution of manganese dioxide. When ferromanganese crust of similar mineralogy to manganese nodules was leached using At. ferrooxidans with elemental sulfur as substrate, nickel and copper were dissolved rapidly and cobalt, manganese and iron dissolved as the $\mathrm{pH}$ decreased, due to sulfur biooxidation [335]. The substitution of pyrite for elemental sulfur was effective and bacterial adaptation to the crust material resulted in increased extraction rates. Similar enhanced extraction was recorded when low-grade manganese ores were bioleached with pyrite addition [336] and the substitution of nickel sulfide for elemental sulfur also resulted in enhanced manganese and cobalt extraction from manganese nodules [337].

In a process developed for the dissolution of manganese nodules containing four elements $(\mathrm{Cu}, \mathrm{Zn}$, $\mathrm{Ni}$ and $\mathrm{Co}$ ), the acid required for leaching was generated from sulfur biooxidation by At. ferrooxidans or At. thiooxidans (mesophiles, $30^{\circ} \mathrm{C}$ ) or Acidianus brierleyi (thermophiles, $65^{\circ} \mathrm{C}$ ) [338]. Many tests aimed at optimising process parameters for metals extraction were included in that study, with a final test conducted under optimised conditions. Distinctive features of the process were the differences in leaching behaviour for the target metals, the strong temperature dependence (accelerated extraction at $65{ }^{\circ} \mathrm{C}$ ), and the selective leaching of base metals and manganese against negligible extraction of iron. The consumption of elemental sulfur was an unavoidable cost in the process. To mitigate the cost of sulfur, Konishi et al. [338] proposed that sulfate could be reduced to hydrogen sulfide using SRB and then, using photosynthetic bacteria, the hydrogen sulfide could be oxidised to elemental sulfur for recycle to the process. Zafiratos et al. [190] developed a stirred-tank process for which the 
techno-economic assessment was favourable. They used a mixed culture of At. ferrooxidans-like strains isolated from different mine sites and grown in medium containing elemental sulfur in a two-stage process involving acid leaching of the test ore $(20 \% \mathrm{Mn}, 1 \% \mathrm{Fe})$ under aerobic and then anaerobic conditions to yield a $\mathrm{pH}$ 1-2 solution with manganese $\left(12 \mathrm{~g} \cdot \mathrm{L}^{-1}\right)$ and iron $\left(0.65 \mathrm{~g} \cdot \mathrm{L}^{-1}\right)$. Iron was removed in a neutralisation stage and disposed of, while manganese in $\mathrm{pH} 7-8$ solution was recovered by electrolysis.

The strategy of exploiting the sulfur-oxidising capability of some chemolithotrophs to provide acid was also trialled for the extraction of nickel from nickel laterites. In bioleaching tests using mixed cultures of At. ferrooxidans, At. caldus and L. ferrooxidans it was found that elemental sulfur supported bacterial growth, acidification and nickel recovery more strongly than if pyrite was used as the substrate [331,332,339]. Under optimised conditions, $2.6 \%$ solids loading, $63 \mu \mathrm{m}$ ore particle size, initial pH 2 and elemental sulfur as substrate, the nickel yield was $74 \%$ in 26 days [332]. Kumari and Natarajan [340] described a micro-aerobic leaching system utilising At. ferrooxidans and At. thiooxidans to oxidise elemental sulfur, with and without added sucrose (reducing agent), to leach manganese nodules. In inoculated tests without sucrose, extractions were $\mathrm{Cu} \geq \mathrm{Ni}(50 \%-60 \%$ in 8 days) $>>\mathrm{Co}>\mathrm{Fe}>\mathrm{Mn}$ for both test species. However, bioleaching in the presence of sucrose provided sufficiently reducing conditions at lower $\mathrm{pH}$ to reduce manganese and iron(III) oxides and enhance acid dissolution with the concomitant release of the ancillary elements copper, nickel and cobalt.

\subsection{Leaching with Acidophilic Heterotrophs/Organic Acid}

The use of heterotrophic bacteria or fungi to leach nickel and cobalt from laterites or manganese oxide ores relies upon the bio-production of organic chelating acids (especially carboxylic acids) or other metabolic products from supplied substrates. In their review on the biohydrometallurgy of non sulfide minerals, Jain and Sharma [341] listed bacteria (four genera) and fungi (seven genera) that produced organic acids during fermentation. Oxalic acid (dicarboxylic acid) and citric acid (tricarboxylic acid) are produced by many fungal species, especially Aspergillus and Penicillium spp., during the metabolism of carbohydrates.

Examples of the application of heterotrophs include the extraction of potassium from leucite (a silicate mineral) [233], extraction of copper and zinc from oxidised copper and lead-zinc ores, respectively [342], bioleaching of aluminium from clays [343], and the extraction of nickel from lateritic materials [31,76,316,319,324,344]. Extractions of $97 \% \mathrm{Cu}, 98 \% \mathrm{Ni}, 86 \% \mathrm{Co}$ and $91 \% \mathrm{Mn}$ from manganese nodules were reported by Das et al. [345]. In each of those studies Aspergillus and/or Penicillium were among the genera tested.

The acids have a dual function, to provide protons for mineral corrosion and to chelate soluble metals. Often, as a prelude to bioleaching, chemical leaching tests using the acids were undertaken to assess and compare their efficacy in metals extraction. For example, in comparative tests Bosecker [31] examined the extraction of nickel by fifteen organic acids using laterites from New Caledonia, Australia, Brazil and the Philippines, and concluded that citric acid was effective for nickel extraction from silicates but not for nickel extraction from iron oxides in laterite ores. In contrast, using laterite ores from Western Australia and Indonesia, McKenzie et al. [346] reported that citric, tartaric and pyruvic acids increased the yield of soluble nickel for limonite type ores. In a comparative study, 
Das et al. [347] showed that oxalic acid was more efficient at extracting manganese (66\%) than citric acid (40\%) from low-grade ferromanganese ore, attributing the difference to the reducing capacity of oxalic acid and its affinity for manganese complexation.

The method is seemingly simple but, compared with traditional bioleaching using chemolithotrophs, the use of heterotrophs presents different challenges and is yet to be commercialised as a stand-alone biotechnology. These challenges have been comprehensively reviewed [77] and include:

- the need to provide large amounts of inexpensive sources of organic carbon for the production of the required organic acids in economic scaled-up processes [32,76,348];

- the need to restrict the use of the carbon source to acid-producing species and to prevent the biomass from inhibiting the metal extraction [32,77];

- the low and variable tolerance exhibited by different fungal species to soluble elements in process solutions and the resultant reduced acid production [76,325,326,349];

- the need to dispose of the biomass [350]; and

- differences in extraction rates and affinities of extracted metals for the minerals in saprolite, nontronite and limonite ores [328].

Nickel and cobalt are the main elements recovered from laterites but in some instances the economics of a process might be improved by extracting additional elements. Zhang and Cheng [313] noted that the ratio of Ni:Mn in laterite ores at Murrin Murrin (Western Australia) is 2:1 and estimated that about 18,000 ton per annum of manganese is discarded to a waste stream.

The paucity of studies using heterotrophic bacteria to generate organic acids suggests that they are less productive. However, Sukla et al. [319] found that nickel extraction using B. circulans (85\% in 20 days) compared favourably with that using A. niger ( $92 \%$ in 20 days). A Bacillus sp. strain was isolated from seawater and applied to the leaching of marine nodules [351]. In saline growth medium ( $\mathrm{pH}$ 8.2) containing $1 \%$ ground nodule material (50-75 $\mu \mathrm{m}$ particle size range) inoculated with actively growing Bacillus sp. culture, extractions of copper, cobalt, nickel and manganese were in the range of $20 \%-30 \%$ for $4-\mathrm{h}$ leach duration. When starch (1\%) was included in the growth medium to create reducing conditions, extractions in the range of $80 \%-85 \%$ for cobalt, copper and manganese, and $65 \%$ for nickel were achieved in $4 \mathrm{~h}$ [351].

\subsection{Reductive Bioleaching (Organic Carbon Compound as Electron Donor)}

Numerous microorganisms have been shown to reduce iron(III) during the metabolism of carbon compounds, fewer to reduce manganese(IV), uranium(VI), and some other elements in various oxidation states [352-354]. In the case of iron(III) and manganese(IV) reduction, these abilities have been harnessed at laboratory scale for the extraction of metals [314,355].

Manganese nodules, with "average" composition (wt \%) 24 Mn, 14 Fe and minor copper, nickel and cobalt, were subjected to systematic study using heterotrophic microorganisms. Thus, similar challenges apply as those identified for the leaching of laterites using heterotrophs. However, because the manganese in nodules is present mainly as manganese dioxide there is the additional need to reduce the manganese(IV) to manganese(II) to render it soluble [314]. 
Most studies were focused on the extraction of manganese and only a few studies included the extraction of ancillary elements. Lee et al. [356] investigated manganese, cobalt and nickel release by manganese-reducing bacteria (not identified). Efficient recovery of metals $(75 \%-80 \%$ after $48 \mathrm{~h}$ of incubation) was achieved during anaerobic leaching at $\mathrm{pH} 5-6.5$ with glucose as the source of organic carbon and temperatures in a range of $30-45{ }^{\circ} \mathrm{C}$. While not directly comparable with other studies, the leach duration was considerably shorter than those reported for fungal production of organic acids [32,357] or the use of RISC-oxidising autotrophs [335].

The release of nickel and cobalt from crushed ferromanganese nodules correlated directly with $\mathrm{MnO}_{2}$ reduction and dissolution when treated with a Bacillus strain [358]. The reduction of manganese(IV) in manganese nodules released simultaneously the ancillary elements copper, nickel and cobalt but not iron. The co-solubilisation of copper, nickel and cobalt was attributed to those elements being bound in the $\mathrm{MnO}_{2}$ matrix, and the poor release of iron as due to the reduction of iron(III) being less favoured than the reduction of $\mathrm{MnO}_{2}$ under the conditions used. A hypothetical anaerobic process utilising manganese(IV)-reducing bacteria was proposed [358] involving the suspension of ground nodules $(-2 \mathrm{~mm})$ at optimal solids loading in salts medium containing a specific organic carbon compound that would act as the electron donor as well as supply carbon for the growth of the selected microorganism(s). Ehrlich et al. [358] thought that a mixture of Geobacter metallireducens, a strict anaerobe, and Sh. putrefaciens, a facultative anaerobe that could scavenge any oxygen initially present in the medium, would provide a suitable culture to reduce manganese(IV) and release $\mathrm{Mn}^{2+}$ and other cations to solution.

A batch and semi-continuous process under micro-aerobic conditions for the bioleaching of ferromanganese minerals was investigated [350]. With molasses as the organic carbon source for the mixed cultures of heterotrophic bacteria, 95\%-100\% Mn extraction was achieved in 36-48 $\mathrm{h}$ of treatment using a solids loading of $20 \%(w / v)$ of ore. Subsequent tests at pilot plant scale, conducted under non-sterile conditions provided evidence that a full-scale process was technically feasible, assuming that a suitable strategy for biomass disposal could be developed, the leach liquor could be purified ahead of manganese separation as the carbonate, and the overall cost of the process could be reduced.

Sh. alga is a facultatively anaerobic bacterium that can couple the oxidation of an organic compound (electron donor) to the reduction of iron(III) and other high-oxidation-state elements [359-361]. Konishi et al. [362] proposed to exploit the capability of Sh. alga to produce ferrous ions that simultaneously affected the dissolution of manganese nodules under anaerobic conditions ( $\mathrm{pH} 7$, ambient temperature). Element solubilisation was rapid, with more than $80 \%$ for $\mathrm{Ni}$, Co and $\mathrm{Mn}$ in $5 \mathrm{~h}$. As a consequence, it was concluded that, as ferromanganese crusts might contain titanium, cerium, zirconium, molybdenum and other elements, further study of the bioleaching behaviour of such elements should be undertaken.

\subsection{Reductive Bioleaching (RISC as Electron Donor)}

Nickel extraction from laterites is strongly dependent on ore mineralogy. Three generic nickel laterite ore types have been described [363,364]; (i) limonite ores in which the nickel is mainly hosted in goethite and in which cobalt- and nickel-enriched manganese oxides may be abundant; (ii) saprolite 
ores with dominant magnesium-nickel hydrous silicates; and (iii) low-quartz, clay silicate deposits with dominant nickel-smectites. Goethitic nickel-laterite ores should be the most amenable to iron(III)-reductive bioleaching.

Hallberg et al. [116] showed that the dissolution of iron(III)-containing laterite ores under anaerobic conditions using At. ferrooxidans in medium supplemented with sulfur resulted in rapid and selective extraction of nickel compared with iron. Johnson et al. [106] monitored nickel, cobalt and manganese recoveries of up to $82 \%, 64 \%$ and $116 \%$, respectively, based on pregnant leach solution (PLS) and feed analysis (head grade), in 20 days of leaching $\left(30{ }^{\circ} \mathrm{C}, \mathrm{pH} 1.8\right)$. The use of sulfur and At. ferrooxidans offered the added advantages that sulfur is generally less costly than a suitable organic compound for use with heterotrophs, can be separated and recycled if not utilised during leaching, and lowered the overall amount of acid required for the proposed process. Further evaluation of the proposed "Ferredox" process, was undertaken [365] with the development of a conceptual flowsheet that incorporated four process components: (i) bioreductive leaching of limonite resulting in a pregnant leach solution (PLS) containing ferrous ion; (ii) extraction of metal values from the PLS; (iii) ferrous ion biooxidation in PLS generating either soluble ferric sulfate or iron(III) oxysulfate precipitates that can be used to regenerate sulfuric acid; and (iv) a bioreductive acid-generation step (ferric ion oxidation of sulfur) and re-cycle to the leaching stage. It was noted that, while the process components had been demonstrated independently in other studies, their integration into a process flowsheet would require further development [365]; six key steps towards that goal were described.

\section{Biotechnologies for Polymetallic Mine Waste and Tailings}

Waste materials at mines comprise material that must be moved to expose the target mineralisation, material that is intermixed with the target mineralisation and thus of lower grade or otherwise unsuited to the selected mineral processing route, and residues from processing, often flotation tailings. The historical context of the large waste dumps and flotation tailings impoundments that litter the world's metal-rich mining regions was briefly described in a succinct, informative and timely review on "Sustainability in metal mining" [366] where it was noted that, at the time of mining, mine waste would contain metal grades lower than can be extracted economically, waste stockpiles could contain metal grades higher than are generally present in the earth's crust. Not surprisingly, the older the stockpile, the greater that difference, because modern extraction methods have become more efficient, driven by the need to process ores of lower grades (Figure 2). According to Mudd [367], "the extent of waste rock or overburden produced by mining is closely linked to the [increased] use and scale of open cut mining". Shaw et al. [368] presented an estimate for global mine waste of "several thousand million tonnes per year" and noted that as demand for metals "is expected to grow for the foreseeable future, it is likely that mine waste generation will follow a similar trend."

Regulatory frameworks for mining industries, with regard to mining practices, water use and its contamination, and mine waste management, have been implemented in industrialised countries from about the 1970s and more recently in developing countries. The scarcity of new, high-grade resources, the need for regulatory compliance and the rising costs of environmental remediation have together created a "developing interest in the recovery of resources from mine waste" [368]. 


\subsection{Waste and Tailings from Sulfide Ores}

Tailings and waste from sulfidic deposits are more problematic than those from oxidised ores because the residual sulfide grains in the material are exposed to oxidising conditions. The numerous reports in the literature on acid mine drainage and the need for its prevention or remediation are testament to the reactivity of, and subsequent rapid metal mobilisation from, disturbed sulfidic waste ores or tailings. Some post-2000 examples of the application of developed bioleaching technologies (see Section 2) to polymetallic mine waste and tailings for the extraction of base and precious metals are summarised. Among those studies there are examples of various biotechnologies:

- the application of direct bioleaching/biooxidation using autotrophic acidophiles in batch reactors, stirred tanks, vats or heaps, the latter with or without the ground tailings being supported on host rocks [369-375];

- the application of heterotrophic microorganisms/organic acids to treat sulfidic tailings comparing direct and indirect bioleaching [376];

- $\quad$ studies directed towards a fundamental understanding of ARD and the development of strategies to mitigate its impact [282,377-381];

- $\quad$ studies driven by anticipated values contained in mine waste and tailings dumps that could support dump remediation or removal [88,382-386]; or

- modifications of developed technologies on a case-by-case basis, to accommodate peculiarities of the tailings arising from their mineralogy, prior treatment and/or storage, or as means of accelerating metals extraction [370,387-389].

The Kasese project (Uganda), is the only application of base-metal stirred tank biotechnology to have been commercialised thus far. According to Morin and d'Hugues [187], it is "the first industrial installation incorporating bioleaching into a sophisticated hydrometallurgical flowsheet allowing the selective extractions of various metals." As background to the project, 16 million tons of copper were produced from the Kilembe deposit, Uganda, in the period 1956-1982. The flotation tailings stockpile near Kasese (900,000 t; 80\% pyrite containing 1.38\% Co) became dispersed by heavy rainfall, produced acid, and was a threat to a national park, a large lake and the local communities. After 10 years of process development at the Bureau de Recherches Géologiques et Minières (BRGM), France, bioleach tanks on site were inoculated in 1998 (Figure 7) and the process of cobalt (zinc, copper and nickel) production and tailings remediation was initiated [187]. Since commissioning, process improvements were undertaken by the plant operators to overcome unforeseen technical difficulties. The Kasese Cobalt Company Limited closed the plant in 2013 through a lack of raw materials but it may be re-opened by Tibet Hima Mining to process cobalt from the Kilembe mines [390].

BacTech Mining Corporation is raising funds for a pilot plant at Cobalt, Ontario, to process tailings from the Castle Mine $50 \mathrm{~km}$ to the west of Cobalt, with the potential to expand capacity and process other tailings from nearby locations (Figure 8) [391,392]. BacTech intends to apply its proprietary bioleaching technology to the remediation of arsenic-rich tailings (potentially 16-18 million tonnes) that also contain recoverable silver, cobalt and nickel. In this process iron(III) and arsenic(V) will be precipitated as ferric arsenate (scorodite) for safe disposal [392]. The successful installation of a biohydrometallurgical process at Cobalt, Ontario, will benefit the environment and local 
communities and will provide confidence in the technology, leading to other cost-effective tailings-remediation projects.
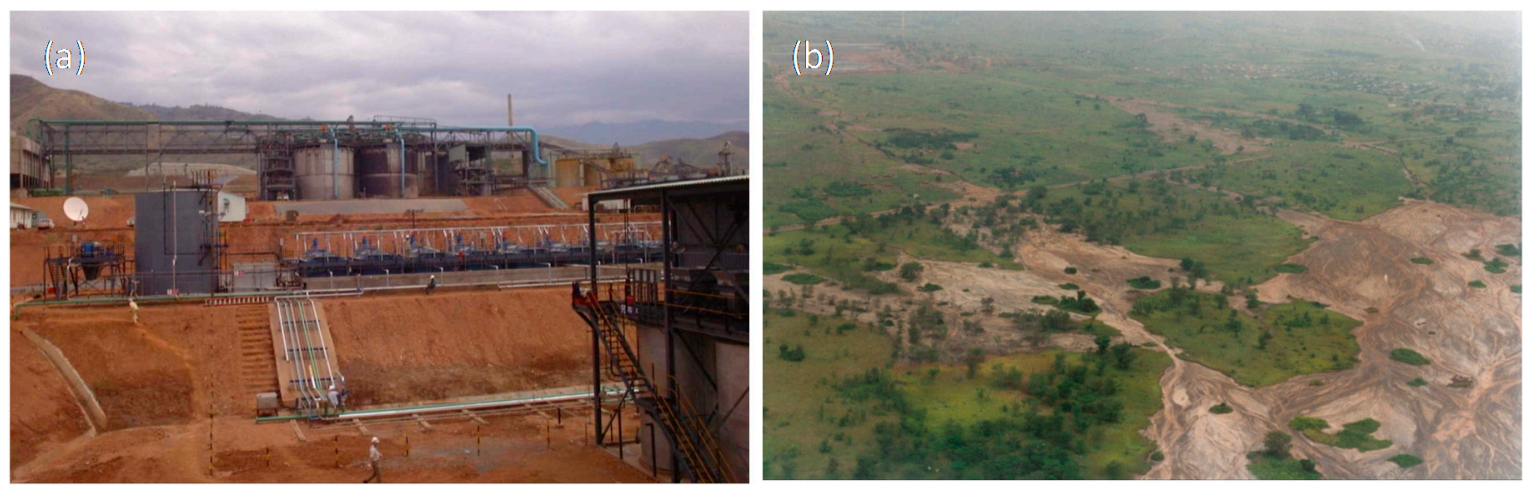

Figure 7. Bioleaching plant (a) for the processing of pyritic tailings (b) containing cobalt, copper, nickel and zinc. Photographs from D. Morin, Bureau de Recherches Géologiques et Minières (BRGM), reprinted with permission.
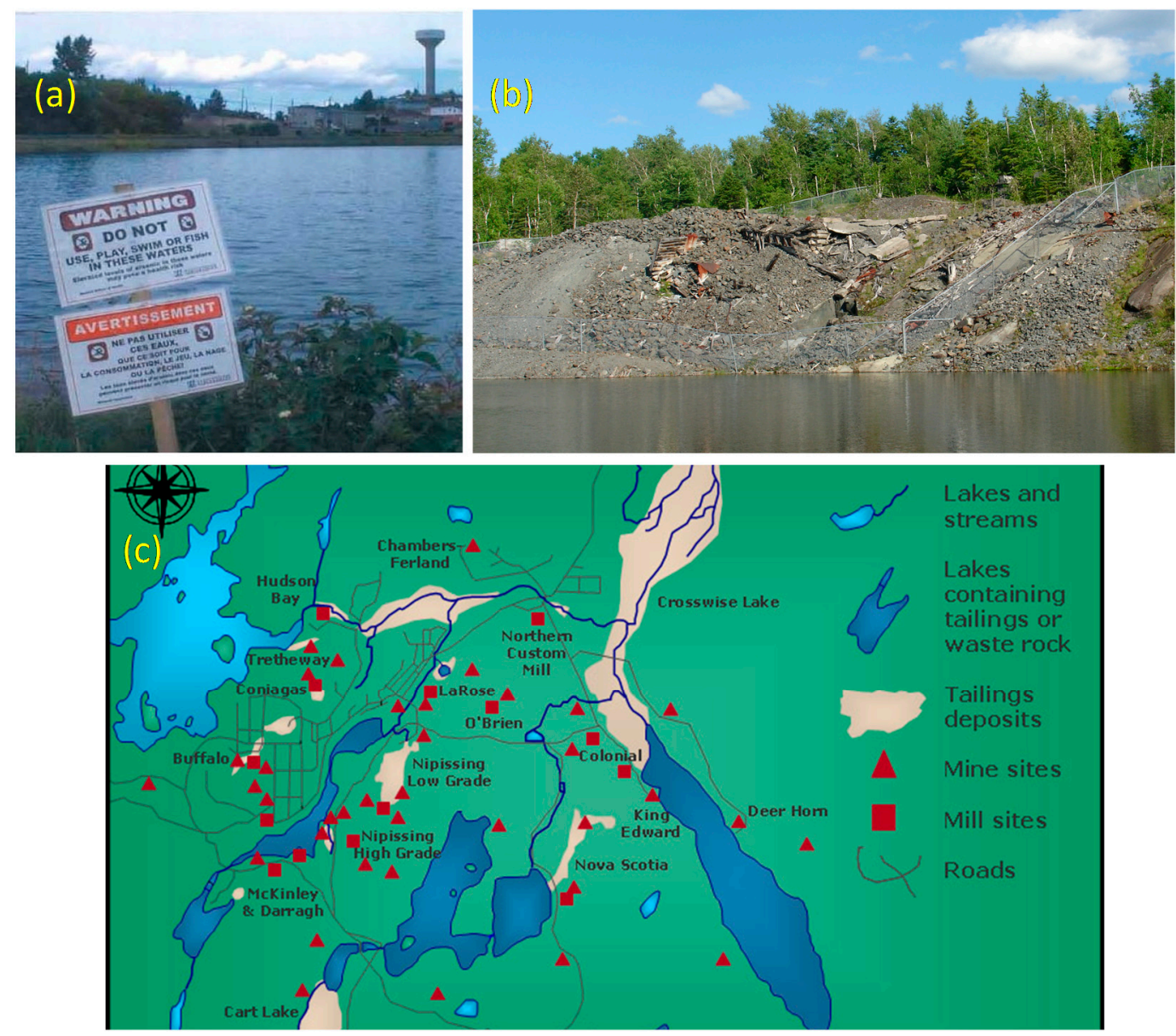

Figure 8. Water (a) and tailings (b) severely contaminated with arsenic; (c) Regional map of old workings in the region near Cobalt, Ontario, Canada with extensive tailings deposits indicated. Pictures from P.C. Miller, BacTech Environmental, reproduced with permission.

In a third tailings project relying on values from cobalt (copper and gold) production to offset the cost of remediation, a process for the in-situ bio-oxidation $\left(i-\mathrm{BO}^{\mathrm{TM}}\right)$ of refractory tailings dumps 
(4 million tonnes) at the Peko Mine, Tennant Creek, Australia was developed [393,394]. The strategy was to accelerate the natural weathering of the tailings by scarifying the tailings surface, introducing large numbers of chemolithotrophic bacteria, and allowing the ingress of oxygen and carbon dioxide from air. Periodic irrigation and collection of drainage facilitated base metals extraction. It was planned that leached residues would be returned to the open-cut mine after gold extraction. The bacterial activity also cleaned up the magnetite, making it another commercial product. Unfortunately, low commodity prices forced the mine into care and maintenance (2010) before the full potential of the technology could be realised.

\subsection{Waste and Tailings from Oxidised Ores}

Fewer studies on the application of biohydrometallurgy to metals extraction from oxidised waste or tailings and no commercial plants were found during this review. Among those studies were examples of:

- bioleaching in batch reactors, stirred tanks or columns, including one column leaching experiment in which fungi were applied as inoculum [395];

- direct bioleaching in which an autotrophic acidophile supplied with sulfur or another RISC produced sulfuric acid for the extraction of metals from mine waste or tailings [344,396-400];

- direct bioleaching in which heterotrophic fungi produced organic acids when supplied with sources of organic carbon and the organic acids effected metals extraction from oxidised mine waste or tailings [344,395,397-405];

- a two stage process, in which biological acid production and chemical leaching were separated [399];

- optimisation of acid production and metals extraction and improved economics of the process, by trialling low-cost sources of carbon for heterotrophs [401,402] or pre-treating the mine waste [344,403,405];

- $\quad$ reductive (anaerobic) leaching using At. ferrooxidans/sulfur [344,405]; and

- enhanced extraction by applying a surfactant to stimulate microbial growth but reduce carbon-source utilisation [404].

Extractions of two or more of $\mathrm{Ni}, \mathrm{Co}, \mathrm{Zn}, \mathrm{Mn}, \mathrm{Cr}, \mathrm{Fe}$ and $\mathrm{As}$ were reported for different experimental conditions. Some studies were focused on the economic return of metals extraction but others had the goal of clean up and safe disposal of a more benign waste or tailings.

\subsection{Towards Responsible Waste Management}

Whether or not a financial offset is obtainable during the treatment of mine wastes and tailings, stricter regulatory frameworks and increased socio-economic pressures in many countries are compelling the mining industry to move in the direction of more sustainable and cleaner metal production. Mining activity impacts on soils, water and air, by accelerating naturally slow biogeochemical processes through materials disturbance, comminution and exposure of reactive material surfaces to the atmosphere. Dold [366] notes that "according to the United States Environmental Protection Agency (EPA), water contamination from mining is one of the top three 
ecological-security threats in the world." The mining and processing of ores may occur on a relatively short time frame but the wastes generated may react for decades to centuries.

The few examples of bioprocesses for the extraction of metals from polymetallic waste materials summarised above apply known methods for the reduction of potentially hazardous components. Not surprisingly, most applications were applied to sulfidic materials that may generate acid over long periods. Some recent microbiological approaches to securing mine wastes and recovering metals from mine waters are highlighted in a review published in this journal ([406] and references therein). The review covers a number of chemical methods for remediation of mine water, some of which have been commercialised but relevant to this review are the bioprocesses, including:

- understanding systems that display "natural attenuation" of contaminated water with a view to exploiting them;

- "bioshrouding" - the formation of biofilms around pyrite grains by heterotrophic microorganisms to limit the attachment of pyrite-oxidising acidithiobacilli;

- "ecological engineering" to reverse the reactions that generate ARD-inoculating freshly-deposited tailings with acidophilic algae and heterotrophic bacteria, sustaining the growth of iron(III)- and sulfate-reducing bacteria within the submerged tailings

- iron oxidation and removal from AMD - in a continuous three-stage modular bioreactor comprising (i) an iron(II)-oxidation reactor inoculated with "Ferrovum myxofaciens"; (ii) a schwertmannite precipitation reactor and (iii) a packed bed polishing unit and

- $\quad$ selective precipitation of copper and zinc and other elements as sulfides from mine waters using acidophilic SRB

- $\quad$ using neutral or acidic SRB to convert sulfate to elemental sulfur for removal;

Knowledge gained from research into both the processing of ores for metals extraction and the remediation of acid mine/rock drainage systems, are together invaluable for mine waste management. The processes developed from them for application in the mining industry, while challenging, should "improve the economic outcome of an ore deposit on the long-term perspective by extracting the complete metal content and prevent the uncontrolled release of contaminants to the environment" [366].

\section{Summary}

Diminishing ore grades and estimates that many valued elements may become exhausted in 50 years (a short time in process development terms) versus increased demand for many elements in the periodic table are the key drivers for:

- a longer-term view of what constitutes a mineral resource and a broader approach to what elements can be extracted, co-extracted, and/or separated from resultant process solutions;

- the development of efficient new or modified technologies for the extraction of a suite of elements, rather than the most lucrative element, from complex polymetallic ores, concentrates, mine wastes and tailings, thereby gaining as much benefit as possible from the considerable costs of mining, moving and pre-treating large tonnages of materials;

- discarding waste and tailings that are benign, thus lowering the costs of environmental remediation during mine closure; and 
- concomitant development of new separation and purification technologies for the recovery of all elements of interest in the multiple-product mines of the future.

Not all of these challenges will be met using bioprocessing, but the claim may reasonably be made that the key technologies for acid-soluble oxidic or lateritic mineral resources and oxidisable sulfidic mineral resources are robust and proven.

- Heap and dump leaching/bioleaching can be a secondary process or a stand-alone technology applied across a wide range of climatic conditions in terrain that is complex and/or remote. Its flexibility makes it suited to deposits from small to very large and each of the unit processes can be very basic (the use of cementation or precipitation to recover metal products).

- The widespread adoption of stirred tanks for the processing of refractory gold ores and concentrates is one of the success stories of mining biotechnology. Stirred tank processes have been piloted and/or demonstrated for the processing of base metals and in one instance commercialised for cobalt production from tailings.

- Both technologies have benefited from improved SW-EW for the separation and recovery of an increased number of elements through the development of novel reagents.

In my view, the main technology that would benefit from systematic study and further development are vat (bio)reactors. Vats (saturated reactors) need to be redesigned to make them "user friendly" on mine sites where large amounts of ores are processed on a daily basis. Continuous reactors are essential but other design advances should include features that make conditions more conducive to chemical-, electrical- and/or microbial-assisted leaching under controlled but variable conditions. A key advantage that could be exploited is that ores can be crushed to finer particle sizes than is possible in heaps, thereby liberating a greater proportion of the target mineral grains and increasing extraction rates as a result.

With respect to the processing of polymetallic sulfidic concentrates, there is a wealth of knowledge available from studies on "pure" concentrates to build upon. Direct bioleaching, indirect bioleaching with the separation of microbial growth and ferric iron generation from chemical leaching, and hybrid processes comprised of chemical leaching and bioleaching have been developed for polymetallic concentrates using stirred tanks, and in some cases integrated flowsheets described. Considerable research on the polymetallic Kupferschiefer shale was undertaken as part of the Bioshale FP6 project but it was concluded that (at the present time) the grades for nickel, copper and zinc were too low for the process to be economic.

Sulfide ores, with or without high organic content, are also low grade and unlikely to be processed economically in stirred tanks (other than peculiarly rich gold-silver ores). Testwork has therefore mainly been focused on heap, dump, in situ or in stope bioleaching, strategies to mitigate acid consumption while maintaining conditions conducive to microbial growth, and some hybrid processes for multi-element processing. The main commercial development is the Talvivaara heap leach yielding nickel, cobalt, copper, zinc and possibly uranium and manganese products, but of greater benefit to biomining would be the interest generated among other mining companies with polymetallic deposits of similar mineralogy. Research into in situ or in stope bioleaching are an important part of the future for mineral processing because they may be the means of accessing deposits too deep for economical extraction by current underground mining technology and they are of interest also from the points of 
view of environmental and community acceptance. Therefore, it is noteworthy that a key objective of the recently initiated, European-funded, BioMOre project is to extract metal from deep mineralised zones by coupling solution mining (in situ or in stope processing) with bioleaching.

The bioleaching of oxidised ores such as laterites and manganese oxide ores have a long history but as yet no commercial processes have been developed. Three modes of leaching are employed, depending upon ore mineralogy: (i) the production or acid for direct bioleaching processes; and/or (ii) the production of acid and complexing agents; and (iii) the conduct of bioleaching under conditions amenable to redox reactions.

The need to provide low-cost carbon sources for those microorganisms that produce organic acids, the requirement to control growth conditions to maximise the production of an effective organic acid, the fact that organic acids are not as strong as inorganic acids, and the need in some cases to dispose of large amounts of biomass, are challenges that have yet to be overcome in the development of a large-scale, integrated process. Nevertheless, some innovative processes have been trialled.

One such process exploited sulfur biooxidation of elemental sulfur as a means of generating the required acid for the dissolution of oxidised ores such as manganese nodules or nickel laterites. There are two perceived benefits: (i) the cost of elemental sulfur is often lower than the cost of equivalent amounts of sulfuric acid; and (ii) other metabolic products from the microorganisms may enhance leaching. The further benefit of changing leaching conditions from aerobic to anaerobic introduced the possibility of reducing iron(III) compounds such as goethite or manganese(IV) compounds such as manganese dioxide. In the case of laterites, where nickel and other elements are held in the goethite crystal matrix, this strategy releases them to solution; in the case of manganese nodules, reductive leaching causes solubilisation of the $\mathrm{MnO}_{2}$ and any ancillary elements. This process exploits the natural ability of some autotrophs to couple iron(III) reduction with sulfur oxidation under anaerobic conditions and is worthy of further research.

The processing of mine waste, overburden and tailings can serve two purposes, (i) the extraction of values from discarded materials perhaps quite high in concentration because historic processes were inefficient and (ii) a means of cleaning up a mine environment as part of closure. Processes in which mine remediation is supported by the extraction of values are a bonus. All of the above technologies have been trialled separately or in combination. A successful application of stirred tank technology to the clean up tailings from a copper mine, supported by the production of cobalt from the pyritic tailings, is the best example of a multiple-product ( $\mathrm{Co}, \mathrm{Zn}, \mathrm{Cu}$ and $\mathrm{Ni}$ ) stirred-tank base-metal leaching process. It is planned to apply a similar stirred-tank process to the remediation of extensive arsenic-contaminated tailings, leading to the safe disposal of benign leached residues. Many of the technologies and their variations have been trialled for the remediation of oxidised ore wastes but none are known to have been implemented thus far. More generally, new bioprocesses to secure reactive tailings and to remove metals from ARD are being developed.

\section{Acknowledgments}

The author thanks D.B. Johnson, P.C. Miller, D.H.R. Morin, T. Prior, D.E. Ralph and D.W. Shiers for helpful discussions, review of the manuscript, and/or permission to use illustrative material. The 
financial support of the Australian Government through the CSIRO Mineral Resources Flagship is gratefully acknowledged.

\section{Conflicts of Interest}

The author declares no conflict of interest.

\section{References}

1. Zinc Commodity Update. Available online: www.hdrsalva.com/market-news/zinc-commodityupdate (accessed on 22 October 2014).

2. Critical Metals for Future Sustainable Technologies and Their Recycling Potential. Available online: www.unep.fr/scp/publications/details.asp?id=DTI/1202/PA (accessed on 22 October 2014).

3. Graedel, T.E.; Cao, J. Metal spectra as indicators of development. Proc. Natl. Acad. Sci. USA 2010, 107, 20905-20910.

4. Reller, A.; Bublies, T.; Staudinger, T.; Oswald, I.; Meissner, S.; Allen, M. The mobile phone: Powerful communicator and potential metal dissipator. GAIA 2009, 18, 127-135.

5. Dodson, J.R.; Hunt, A.J.; Parker, H.L.; Yang, Y.; Clark, J.H. Element sustainability: Towards the total recovery of scarce metals. Chem. Eng. Process. 2012, 51, 69-78.

6. Backman, C.M. Global supply and demand of metals in the future. J. Toxicol. Environ. Health 2008, 71, 1244-1253.

7. Prior, T.; Giurco, D.; Mudd, G.; Mason, L.; Behrisch, J. Resource depletion, peak minerals and the implications for sustainable resource management. Glob. Environ. Chang. 2012, 22, 577-587.

8. West, J. Decreasing metal ore grades: Are they really being driven by the depletion of high-grade deposits? J. Ind. Ecol. 2011, 15, 165-168.

9. Crowson, P. Some observations on copper yields and ore grades. Resour. Policy 2012, 37, 59-72.

10. USGS Minerals Yearbooks 1994-2011 and Mineral Commodity Summaries 2012-2014. Available online: http://minerals.usgs.gov/minerals/pubs/commodity/ (accessed on 22 October 2014).

11. World Copper Factbook 2013. Available online: http://www.icsg.org/index.php/component/ jdownloads/finish/170/1188 (accessed on 22 October 2014).

12. The Outlook for Metals Markets. World Bank: Washington, DC, USA, 2006. Available online: http://siteresources.worldbank.org/INTOGMC/Resources/outlook_for_metals_market.pdf (accessed on 22 October 2014).

13. Cui, J.; Zhang, L. Metallurgical recovery of metals from electronic waste: A review. J. Hazard. Mater. 2008, 158, 228-256.

14. Pathak, A.; Dastidar, M.G.; Sreekrishnan, T.R. Bioleaching of heavy metals from sewage-sludge: A review. J. Environ. Manag. 2009, 90, 2343-2353.

15. Lee, J.; Pandey, B.D. Bio-processing of solid wastes and secondary resources for metal extraction-A review. Waste Manag. 2012, 32, 3-18.

16. Krebs, W.; Brombacher, C.; Bosshard, P.P.; Bachofen, R.; Brandl, H. Microbial recovery of metals from solids. FEMS Microbiol. Rev. 1997, 20, 605-617.

17. Hoque, M.E.; Philip, O.J. Biotechnological recovery of heavy metals from secondary sources-An overview. Mater. Sci. Eng. C 2011, 31, 57-66. 
18. Asghari, I.; Mousavi, I.M.; Amiri, F.; Tavassoli, S. Bioleaching of spent refinery catalysts. J. Ind. Eng. Chem. 2013, 19, 1069-1081.

19. Kelly, D.P.; Wood, A.P. Reclassification of some species of Thiobacillus to the newly designated genera Acidithiobacillus gen. nov., Halothiobacillus gen. nov. and Thermithiobacillus. gen. nov. Int. J. Syst. Evol. Microbiol. 2000, 50, 511-516.

20. Rudolfs, W.; Helbronner, A. Oxidation of zinc sulfide by microorganisms. Soil Sci. 1922, 14, 459-464.

21. Colmer, A.R.; Temple, K.L.; Hinkle, H.E. An iron-oxidizing bacterium from the acid mine drainage of some bituminous coal mines. J. Bacteriol. 1950, 59, 317-328.

22. Temple, K.L.; Colmer, A.R. The autotrophic oxidation of iron by a new bacterium: Thiobacillus ferrooxidans. J. Bacteriol. 1951, 62, 605-611.

23. Leathen, W.W.; Braley, S.S., Sr.; McIntyre, L.D. The role of bacteria in the formation of acid from sulfuritic constituents associated with bituminous coal: II. Ferrous iron oxidizing bacteria. Appl. Microbiol. 1953, 1, 65-68.

24. Bryner, L.C.; Beck, J.V.; Davis, D.B.; Wilson, D.G. Microorganisms in leaching sulfide minerals. Ind. Eng. Chem. 1954, 46, 2587-2592.

25. Bryner, L.C.; Anderson, R. Microorganisms in leaching sulfide minerals. Ind. Eng. Chem. 1957, 49, 1721-1724.

26. Bryner, L.C.; Jameson, A.K. Microorganisms in leaching sulfide minerals. Appl. Microbiol. 1958, 6, 281-287.

27. Rawlings, D.E. Mesophilic autotrophic bioleaching bacteria: Description, physiology and role. In Biomining: Theory, Microbes and Industrial Processes; Rawlings, D.E., Ed.; Springer-Verlag: Berlin, Germany, 1997; pp. 229-245.

28. Norris, P.R. Thermophiles and bioleaching. In Biomining: Theory, Microbes and Industrial Processes; Rawlings, D.E., Ed.; Springer-Verlag: Berlin, Germany, 1997; pp. 247-258.

29. Hallberg, K.B.; Johnson, D.B. Biodiversity of acidophilic prokaryotes. Adv. Appl. Microbiol. 2001, 49, 37-84.

30. Watling, H.R. The bioleaching of sulphide minerals with emphasis on copper sulphides-A review. Hydrometallurgy 2006, 84, 81-108.

31. Bosecker, K. Leaching of lateritic nickel ores with heterotrophic microorganisms. In Fundamental and Applied Biohydrometallurgy; Lawrence, R.W., Branion, R.M.R., Ebner, H.G., Eds.; Elsevier: Amsterdam, The Netherlands, 1986; pp. 367-382.

32. Tzeferis, P.G. Leaching of a low-grade hematitic laterite ore using fungi and biologically produced acid metabolites. Int. J. Miner. Process. 1994, 42, 267-283.

33. Valix, M.; Usai, F.; Malik, R. Fungal bio-leaching of low-grade laterite ores. Miner. Eng. 2001, 14, 197-203.

34. Johnson, D.B.; Roberto, F.F. Heterotrophic acidophiles and their roles in the bioleaching of sulfide minerals. In Biomining: Theory, Microbes and Industrial Processes; Rawlings, D.E., Ed.; Springer-Verlag: Berlin, Germany, 1997; pp. 259-279.

35. Johnson, D.B.; Hallberg, K.B. Carbon, iron and sulfur metabolism in acidophilic micro-organisms. Adv. Microb. Physiol. 2008, 54, 201-255. 
36. Ehrlich, H.L. Beginnings of rational bioleaching and highlights in the development of biohydrometallurgy: A brief history. Eur. J. Miner. Process. Environ. Prot. 2004, 4, 102-112.

37. Hallberg, K.B.; Johnson, D.B. Novel acidophiles isolated from moderately acidic mine drainage waters. Hydrometallurgy 2003, 71, 139-148.

38. Jerez, C.A. The use of genomics, proteomics and other OMICS technologies for the global understanding of biomining organisms. Hydrometallurgy 2008, 94, 162-169.

39. Johnson, D.B. Extremophiles: Acidic environments. In Encyclopedia of Microbiology; Schaechter, M., Ed.; Elsevier: Oxford, UK, 2009; pp. 107-126.

40. Watling, H.R.; Watkin, E.L.J.; Ralph, D.E. The resilience and versatility of acidophiles that contribute to the bio-assisted extraction of metals from mineral sulfides. Environ. Technol. 2010, 31, 915-933.

41. Schultz, M.F.; Benjamin, M.M.; Ferguson, J.F. Adsorption and desorption of metals on ferrihydrite: Reversibility of the reaction and sorption properties of the regenerated solid. Environ. Sci. Technol. 1987, 21, 863-869.

42. Fuller, C.C.; Davis, J.A.; Waychunas, G.A. Surface chemistry of ferrihydrite: Part 2. Kinetics of arsenate adsorption and coprecipitation. Geochim. Cosmochim. Acta 1993, 57, 2271-2282.

43. Cudennec, Y.; Lecerf, A. The transformation of ferrihydrite into goethite or hematite, revisited. J. Solid State Chem. 2006, 179, 716-722.

44. Liu, H.; Li, P.; Zhu, M.; Wei, Y.; Sun, Y. Fe(II)-induced transformation from ferrihydrite to lepidocrocite and goethite. J. Solid State Chem. 2007, 180, 2121-2128.

45. Bigham, J.M.; Nordstrom, D.K. Iron and aluminium hydroxysulfates from acidic sulfate waters. Rev. Mineral. Geochem. 2000, 40, 351-403.

46. Gramp, J.P.; Jones, F.S.; Bigham, J.M.; Tuovinen, O.H. Monovalent cation concentrations determine the types of $\mathrm{Fe}(\mathrm{III})$ hydroxysulfate precipitates formed in bioleach solutions. Hydrometallurgy 2008, 94, 29-33.

47. Carlson, L.; Bigham, J.M.; Schwertmann, U.; Kyek, A.; Wagner, F. Scavenging of As from acid mine drainage by schwertmannite and ferrihydrite: A comparison with synthetic analogues. Environ. Sci. Technol. 2002, 36, 1712-1719.

48. Fukushi, K.; Sato, T.; Yanase, N.; Minati, J.; Yamada, H. Arsenic sorption on schwertmannite. Am. Mineral. 2004, 89, 1728-1734.

49. Regenspurg, S.; Peiffer, S. Arsenate and chromate incorporation in schwertmannite. Appl. Geochem. 2005, 20, 1226-1239.

50. Acero, P.; Ayora, C.; Torrento, C.; Nieto, J.-M. The behavior of trace elements during schwertmannite precipitation and subsequent transformation into goethite and jarosite. Geochim. Cosmochim. Acta 2006, 70, 4130-4139.

51. Wang, H.; Bigham, J.M.; Tuovinen, O.H. Formation of schwertmannite and its transformation to jarosite in the presence of acidophilic iron-oxidizing microorganisms. Mater. Sci. Eng. 2006, 26, 588-592.

52. Sanchez-España, J.; Yusta, I.; López, G.A. Schwertmannite to jarosite conversion in the water column of an acidic mine pit lake. Mineral. Mag. 2012, 76, 2659-2682.

53. Daoud, J.; Karamanev, D. Formation of jarosite during $\mathrm{Fe}^{2+}$ oxidation by Acidithiobacillus ferrooxidans. Miner. Eng. 2006, 19, 960-967. 
54. Sand, W. Microbial mechanisms. In Microbially Influenced Corrosion of Materials; Heitz, E., Flemming, H.-C., Sand, W., Eds.; Springer: Heidelberg, Germany, 1996; pp. 15-25.

55. Sand, W.; Jozsa, P.-G.; Manasch, R. Weathering microbiology. In Environmental Microbiology; Britton, G., Ed.; Wiley: New York, NY, USA, 2002; Volume 6, pp. 3364-3375.

56. Williams, T.M.; Unz, R.F. Filamentous sulfur bacteria of activated sludge: Characterization of Thiothrix, Beggiatoa, and Eikelboom Type 021N strains. Appl. Environ. Microbiol. 1985, 49, 887-898.

57. Grayston, S.J.; Nevell, W.; Wainwright, M. Sulphur oxidation by fungi. Trans. Br. Mycol. Soc. 1986, 87, 193-198.

58. Lang, E.; Jagnow, G. Fungi of a forest soil nitrifying at low $\mathrm{pH}$ values. FEMS Microbiol. Lett. 1986, 38, 257-265.

59. Mansch, R.; Bock, E. Biodeterioration of natural stone with special reference to nitrifying bacteria. Biodegradation 1998, 9, 47-64.

60. Sakai, K.; Ikehata, Y.; Ikenaga, Y.; Wakayama, M.; Moriguchi, M. Nitrite oxidation by heterotrophic bacteria under various nutritional and aerobic conditions. J. Ferment. Bioeng. 1996, 82, 613-617.

61. Schippers, A.; Rohwerder, T.; Sand, W. Intermediary sulfur compounds in pyrite oxidation: Implications for bioleaching and biodepyritization of coal. Appl. Microbiol. Biotechnol. 1999, 52, $104-110$.

62. Pronk, J.T.; Meulenberg, R.; Hazeu, W.; Bos, P.; Kuenen, J.G. Oxidation of reduced inorganic sulfur compounds by acidophilic thiobacilli. FEMS Microbiol. Rev. 1990, 75, 293-306.

63. McNamara, C.J.; Mitchell, R. Microbial deterioration of historic stone. Front. Ecol. Environ. 2005, 3, 445-451.

64. De la Torre, M.A.; Gómez-Alarcón, G.; Vizcaino, C.; Garcia, M.T. Biochemical mechanisms of stone alteration carried out by filamentous fungi living in monuments. Biogeochemistry 1993, 19, $129-147$.

65. Fischer, K.; Bipp, H.P. Removal of heavy metals from soil components and soils by natural chelating agents: Part II. Soil extraction by sugar acids. Water Air Soil Pollut. 2002, 138, 271-288.

66. Uroz, S.; Calvaruso, C.; Turpault, M.P.; Fley-Klett, P. Mineral weathering by bacteria: Ecology, actors and mechanisms. Trends Microbiol. 2009, 17, 378-387.

67. Uroz, S.; Calvaruso, C.; Turpault, M.P.; Sarniguet, A.; de Boer, W.; Leveau, J.H.J.; Frey-Klett, P. Efficient mineral weathering is a distinctive functional trait of the bacterial genus Collimonas. Soil Biol. Biochem. 2009, 41, 2178-2186.

68. Bennett, P.C.; Melcer, M.E.; Siegel, D.I.; Hassett, J.P. The dissolution of quartz in dilute aqueous solutions of organic acids at $25^{\circ} \mathrm{C}$. Geochim. Cosmochim. Acta 1988, 52, 1521-1530.

69. Blake, R.E.; Walter, L.M. Effects of organic acids on the dissolution of orthoclase at $80{ }^{\circ} \mathrm{C}$ and pH 6. Chem. Geol. 1996, 132, 91-102.

70. Hausrath, E.M.; Neaman, A.; Brantley, S.L. Elemental release rates from dissolving basalt and granite with and without organic ligands. Am. J. Sci. 2009, 309, 633-660.

71. Welch, S.A.; Taunton, A.E.; Banfield, J.F. Effect of microorganisms and microbial metabolites on apatite dissolution. Geomicrobiol. J. 2002, 19, 343-367. 
72. Zhang, H.; Bloom, P.R. Dissolution kinetics of hornblende in organic acid solutions. Soil Sci. Soc. Am. J. 1999, 63, 815-822.

73. Di Bonaventura, M.P.; Gallo, M.D.; Cacchio, P.; Ercole, C.; Lepidi, A. Microbial formation of oxalate films on monument surfaces: Bioprotection or biodeterioration? Geomicrobiol. J. 1999, $16,55-64$.

74. Scheerer, S.; Ortega-Morales, O.; Gaylarde, C. Microbial deterioration of stone monuments-An updated overview. Adv. Appl. Microbiol. 2009, 66, 97-139.

75. Sterflinger, K. Fungi as geologic agents. Geomicrobiol. J. 2000, 17, 97-124.

76. Alibhai, K.A.K.; Dudeney, A.W.L.; Leak, D.J.; Agatzini, S.; Tzeferis, P. Bioleaching and bioprecipitation of nickel and iron from laterites. FEMS Microbiol. Rev. 1993, 22, 87-93.

77. Simate, G.S.; Ndlovu, S.; Walubita, L.F. The fungal and chemolithotrophic leaching of nickel laterites - Challenges and opportunities. Hydrometallurgy 2010, 103, 150-157.

78. Neilands, J.B. Siderophores: Structure and function of microbial iron transport compounds. J. Biol. Chem. 1995, 270, 26723-26726.

79. Boukhalfa, H.; Reiley, S.D.; Michalczyk, R.; Iyer, S.; Neu, M.P. Iron(III) coordination properties of a pyoverdin siderophore produced by Pseudomonas putida ATCC 33015. Inorg. Chem. 2006, 45, 5607-5616.

80. Duckworth, O.W.; Bargar, J.R.; Sposito, G. Coupled biogeochemical cycling of iron and manganese as mediated by microbial siderophores. Biometals 2009, 22, 605-613.

81. Kraemer, S.M. Iron oxide dissolution and solubility in the presence of siderophores. Aquat. Sci. 2004, 66, 3-18.

82. Dehner, C.A.; Awaya, J.D.; Maurice, P.A.; du Bois, J.L. Roles of siderophores, oxalate and ascorbate in mobilization of iron from hematite by the aerobic bacterium Pseudomonas mendocina. Appl. Environ. Microbiol. 2010, 76, 2041-2048.

83. Saal, L.B.; Duckworth, O.W. Synergistic dissolution of manganese oxides as promoted by siderophores and small organic acids. Soil Sci. Soc. Am. J. 2010, 74, 2021-2031.

84. Loukola-Ruskeeniemi, K.; Heino, T.; Talvitie, J.; Vanne, J. Base-metal-rich metamorphosed black shales associated with Proterozoic ophiolites in the Kainuu schist belt, Finland: A genetic link with the Outokumpu rock assemblage. Miner. Depos. 1991, 26, 143-151.

85. Loukola-Ruskeeniemi, K. Geochemical evidence for hydrothermal origin of sulphur, base metals and gold in Proterozoic metamorphosed black shales, Kainuu and Outokumpu areas, Finland. Miner. Depos. 1991, 26, 152-164.

86. Tariq, M.; Aziz, A.; Shafiq, M.; Sajjid, M.; Iqbal, M.M.; Muhammad, S. Characterization of black shale of Chimiari Khyber Pakthunkhawa region of Pakistan for its potential as multiminerals. Int. J. Sci. Res. 2013, 2, 231-238.

87. Gouin, J.; Auge, T.; Bailly, L.; d'Hugues, P. Organic and mineral characteristics of Kupferschiefer ore from Lubin mine (Poland): Implications for bioleaching of the ore. In Digging Deeper; Andrew, C.J., Ed.; IAEG: Dublin, Ireland, 2007.

88. Kamradt, A.; Borg, G.; Schaefer, J.; Kruse, S.; Fiedler, M.; Romm, P.; Schippers, A.; Gorny, R.; du Bois, M.; Bieligk, C.; et al. An integrated process for innovative extraction of metals from kupferschiefer mine dumps. Chem. Ing. Tech. 2012, 84, 1694-1703. 
89. Matlakowska, R.; Ruszkowski, D.; Sklodowska, A. Microbial transformation of fossil organic matter of Kupferschiefer black shale-Elements mobilization from metalloorganic compounds and metalloporphyrins by a community of indigenous microorganisms. Physicochem. Probl. Miner. Process. 2013, 49, 223-231.

90. Farbiszewska-Kiczma, J.; Farbiszewska, T.; Bak, M. Bioleaching of metals from Polish black shale in neutral medium. Physicochem. Probl. Miner. Process. 2004, 38, 273-280.

91. Farbiszewska-Kiczma, J.; Farbiszewska, T. Isolation of bacteria that degrade organometallic compounds from metallic wastes. Physicochem. Probl. Miner. Process. 2005, 39, 263-267.

92. Matlakowska, R.; Hallberg, K.B.; Sklodowska, A. Isolation and characterisation of microorganisms from copper-bearing black shale of Lubin mine, Poland. In Biohydrometallurgy: From Single Cell to the Environment; Schippers, A., Sand, W., Glombitza, F., Willscher, S., Eds.; TransTech Publications: Zurich, Switzerland, 2007; p. 580.

93. Matlakowska, R.; Sklodowska, A. The culturable bacteria isolated from organic-rich black shale potentially useful in biometallurgical procedures. J. Appl. Microbiol. 2009, 107, 858-866.

94. Matlakowska, R.; Narkiewicz, W.; Sklodowska, A. Biotransformation of organic-rich copper-bearing black shale by indigenous microorganisms isolated from Lubin mine (Poland). Environ. Sci. Technol. 2010, 44, 2433-2440.

95. Itävaara, M.; Nyyssönen, M.; Kapanen, A.; Nousiainen, A.; Ahonen, L.; Kukkonen, I. Characterization of bacterial diversity to a depth of $1500 \mathrm{~m}$ in the Outokumpu deep borehole, Fennoscandian Shield. FEMS Microbiol. Ecol. 2011, 77, 295-309.

96. Li, J.; Sun, W.; Wang, S.; Sun, Z.; Lin, S.; Peng, X. Bacteria diversity, distribution and insight into their role in $\mathrm{S}$ and $\mathrm{Fe}$ biogeochemical cycling during black shale weathering. Environ. Microbiol. 2014, 16, 3533-3547.

97. Petsch, S.T.; Edwards, K.J.; Eglinton, T.I. Microbial transformations of organic matter in black shales and implications for global biogeochemical cycles. Palaeogeogr. Palaeoclimatol. Palaeoecol. 2005, 219, 157-170.

98. Sadowski, Z.; Szubert, A.; Maliszewska, I.; Jazdzyk, E. A view on the organic matter and metalloporphyrins biodegradation as characteristic component of black shale ore. In Biohydrometallurgy: From Single Cell to the Environment; Schippers, A., Sand, W., Glombitza, F., Willscher, S., Eds.; TransTech Publications: Zurich, Switzerland, 2007; pp. 95-98.

99. Matlakowska, R.; Sklodowska, A. Uptake and degradation of copper and cobalt porphyrins by indigenous microorganisms of Kupferschiefer (Fore-Sudetic Monocline, Poland). Hydrometallurgy 2010, 104, 501-505.

100. Matlakowska, R.; Sklodowska, A. Biodegradation of organic matter and release of heavy metals from the copper bearing black shale of Fore Sudetic Monocline (Poland). In Biohydrometallurgy: From Single Cell to the Environment; Schippers, A., Sand, W., Glombitza, F., Willscher, S., Eds.; TransTech Publications: Zurich, Switzerland, 2007; pp. 238-239.

101. Matlakowska, R.; Sklodowska, A. Biodegradation of Kupferschiefer black shale organic matter (Fore-Sudetic Monocline, Poland) by indigenous microorganisms. Chemosphere 2011, 83, $1255-1261$.

102. Ehrlich, H.L. Microbes and metals. Appl. Microbiol. Biotechnol. 1997, 48, 687-692. 
103. Lyalikova, N.N.; Vedenina, I.Y.; Romanova, A.K. Assimilation of carbon dioxide by a culture of Stibiobacter senarmontii. Microbiology 1976, 45, 476-477.

104. Ilyaletdinov, A.N.; Abdrashitova, S.A. Autotrophic arsenic oxidation by Pseudomonas arsenitoxidans culture. Mikrobiologiia 1981, 50, 197-204.

105. Johnson, D.B.; Kanao, T.; Hedrich, S. Redox transformations of iron at extremely low pH: Fundamental and applied aspects. Front. Microbiol. 2012, 3, 96, doi:10.3389/fmicb.2012.00096.

106. Johnson, D.B.; Grail, B.M.; Hallberg, K.B. A new direction for biomining: Extraction of metals by reductive dissolution of oxidized ores. Minerals 2013, 3, 49-58.

107. Johnson, D.B. Selective solid media for isolating and enumerating acidophilic bacteria. J. Microbiol. Methods 1995, 23, 205-218.

108. Johnson, D.B.; Hallberg, K.B. Techniques for detecting and identifying acidophilic mineral-oxidising microorganisms. In Biomining; Rawlings, D.E., Johnson, D.B., Eds.; Springer-Verlag: Berlin, Germany, 2007; pp. 237-262.

109. Valenzuela, L.; Chi, A.; Beard, S.; Orell, A.; Guiliani, N.; Shabanowitz, J.; Hunt, D.F.; Jerez, C.A. Genomics, metagenomics and proteomics in biomining microorganisms. Biotechnol. Adv. 2006, 24, 197-211.

110. Shiers, D.W.; Ralph, D.E.; Watling, H.R. A comparative study of substrate utilisation by Sulfobacillus species in mixed ferrous ion and tetrathionate growth medium. Hydrometallurgy 2010, 104, 363-369.

111. Shiers, D.W.; Ralph, D.E.; Watling, H.R. The effects of nitrate on substrate utilisation by some iron(II)- and sulfur-oxidising Bacteria and Archaea. Hydrometallurgy 2014, 150, 259-268.

112. Suzuki, I.; Takeuchi, T.L.; Yuthasastrakosol, T.D.; Oh, J.K. Ferrous iron and sulfur oxidation and ferric iron reduction activities of Thiobacillus ferrooxidans are affected by growth on ferrous iron, sulfur or a sulfide ore. Appl. Environ. Microbiol. 1990, 56, 1620-1626.

113. Sugio, T.; Tsujita, Y.; Katagiri, T.; Inagaki, K.; Tano, T. Reduction of $\mathrm{Mo}^{6+}$ with elemental sulfur by Thiobacillus ferrooxidans. J. Bacteriol. 1988, 170, 5956-5959.

114. Sugio, T.; Tsujita, Y.; Inagaki, K.; Tano, T. Reduction of cupric ions with elemental sulfur by Thiobacillus ferrooxidans. Appl. Environ. Microbiol. 1990, 56, 693-696.

115. Bridge, T.A.M.; Johnson, D.B. Reduction of soluble iron and reductive dissolution of ferric-iron containing minerals by moderately thermophilic iron-oxidizing bacteria. Appl. Environ. Microbiol. 1998, 64, 2181-2186.

116. Hallberg, K.B.; Grail, B.M.; du Plessis, C.A.; Johnson, D.B. Reductive dissolution of ferric iron minerals: A new approach for Bioprocessing nickel laterites. Miner. Eng. 2011, 24, 620-624.

117. Johnson, D.B.; Stallwood, B.; Kimura, S.; Hallberg, K.B. Isolation and characterization of Acidicaldus organivorus, gen. nov., sp. nov.: A novel sulfur-oxidizing, ferric iron-reducing thermoacidophilic heterotrophic Proteobacterium. Arch. Microbiol. 2006, 185, 212-221.

118. Coupland, K.; Johnson, D.B. Evidence that the potential for dissimilatory ferric iron reduction is widespread among acidophilic heterotrophic bacteria. FEMS Microbiol. Lett. 2008, 279, 30-35.

119. Bridge, T.A.M.; Johnson, D.B. Reductive dissolution of ferric iron minerals by Acidiphilium SJH. Geomicrobiol. J. 2000, 17, 193-206.

120. Muyzer, G.; Stams, A.J.M. The ecology and biotechnology of sulphate-reducing bacteria. Nat. Rev. Microbiol. 2008, 6, 441-454. 
121. PAQUES Metal and Mining. Available online: http://en.paques.nl/your-sector/other/metal-andmining (accessed on 22 October 2014).

122. Watling, H. Adaptability of biomining organisms in hydrometallurgical processes. In Biohydrometallurgical Processes: A Practical Approach; Santos Sobral, L.G., Monteiro de Oliveira, D., Gomes de Souza, C.E., Eds.; CETEM/MCTI: Rio de Janeiro, Brazil, 2011; pp. 39-70.

123. Hackl, R.P.; Wright, F.R.; Bruynesteyn, A. Bacteria for Oxidizing Multimetallic Sulphide Ores. US Patent 5,089,412, 18 February 1992.

124. Van Aswegen, P.C.; Haines, A.K.; Marais, H.J. Design and operation of a commercial bacterial oxidation plant at Fairview. In Proceedings of the Randol Gold Conference, Perth, Australia; 28 October-1 November 1988; pp. 144-147.

125. Williams, T.L. Factors affecting bacterial population dynamics at the Youanmi bacterial oxidation plant. In Biotechnology Comes of Age; Australian Minerals Foundation: Glenside, SA, Australia, 1997.

126. Battaglia, F.; Morin, D.; Ollivier, P. Dissolution of cobaltiferous pyrite by Thiobacillus ferrooxidans and Thiobacillus thiooxidans: Factors influencing bacterial leaching efficiency. J. Biotechnol. 1994, 32, 11-16.

127. D’Hughes, P.; Cezac, P.; Cabral, T.; Battaglia, F.; Truong-Meyer, X.M.; Morin, D. Bioleaching of a cobaltiferous pyrite: A continuous laboratory-scale study at high solids concentration. Miner. Eng. 1997, 10, 507-527.

128. Heinzle, T.; Miller, D.; Nagel, V. Results of an integrated pilot plant operation using the BioNIC $^{\circledR}$ process to produce nickel metal. In Biomine' 99 and Water Management in Metallurgical Operations' 99; AusIMM: Melbourne, Australia, 1999; pp. 16-25.

129. Du Plessis, C.A.; Batty, J.D.; Dew, D.W. Commercial applications of thermophile bioleaching. In Biomining; Rawlings, D.E., Johnson, D.B., Eds.; Springer-Verlag: Berlin, Germany, 2007; pp. $57-80$.

130. Duncan, D.W.; Landesman, J.; Walden, C.C. Role of Thiobacillus ferrooxidans in the oxidation of sulfide minerals. Can. J. Microbiol. 1967, 13, 397-403.

131. Shiers, D.W.; Blight, K.R.; Ralph, D.E. Sodium sulphate and sodium chloride effects on batch culture of iron-oxidising bacteria. Hydrometallurgy 2005, 80, 75-82.

132. Suzuki, I.; Lee, D.; McKay, B.; Harahuc, L.; Oh, J.K. Effect of various anions, pH, and osmotic pressure on oxidation of elemental sulfur by Thiobacillus thiooxidans. Appl. Environ. Microbiol. 1999, 65, 5163-5168.

133. Zammit, C.M.; Mutch, L.A.; Watling, H.R.; Watkin, E.L.J. The characterization of salt tolerance in biomining microorganisms and the search for novel salt tolerant strains. In Biohydrometallurgy: A Meeting Point between Microbial Ecology, Metal Recovery Processes and Environmental Remediation; Donati, E.R., Viera, M.R., Tavani, E.L., Giaveno, M.A., Lavalle, T.L., Chiaccharini, P.A., Eds.; TransTech Publications: Zurich, Switzerland, 2009; pp. 283-286.

134. Gahan, C.S.; Sundkvist, J.E.; Dopson, M.; Sandström, Å. Effect of chloride on ferrous iron oxidation by a Leptospirillum ferriphilum-dominated chemostat culture. Biotechnol. Bioeng. 2010, 106, 422-431. 
135. Williams, T.L. BioHeap ${ }^{\mathrm{TM}}$ bacterial leaching of the Sherlock Bay Nickel Mine primary nickel-sulphide ore in saline water. In Proceedings of the ALTA Nickel-Cobalt Conference, Perth, Australia, 15-17 May 2006.

136. Rautenbach, G.F.; Davis-Belmar, C.S.; Demergasso, C.S. A Method of Treating Sulphide Mineral. World Patent, WO2010/009481-A, 21 January 2010.

137. Patel, B.C.; Tipre, D.R.; Dave, S.R. Optimization of copper and zinc extraction from polymetallic bulk concentrate and ferric iron bioregeneration under metallic stress. Hydrometallurgy 2012, 117-118, 18-23.

138. Corbillon, M.S.; Olazabal, M.A.; Madariaga, J.M. Potentiometric study of aluminium fluoride complexation equilibria and definition of the thermodynamic model. J. Solut. Chem. 2008, 37, 567-579.

139. Radic, N.; Bralic, M. Aluminium fluoride complexation and its ecological importance in the aquatic environment. Sci. Total Environ. 1995, 172, 237-243.

140. Sicupira, L.; Veloso, T.; Reis, F.; Leao, V. Assessing metal recovery from low-grade copper ores containing fluoride. Hydrometallurgy 2011, 109, 202-210.

141. Soli, A.L.; Byrne, R.H. The hydrolysis and fluoride complexation behaviour of Fe(III) at $25{ }^{\circ} \mathrm{C}$ and 0.68 molal ionic strength. J. Solut. Chem. 1996, 25, 773-785.

142. Sundkvist, J.E.; Sandström, Å.; Gunneriusson, L.; Lindstrom, E.B. Fluorine toxicity in bioleaching systems. In Proceedings of the 16th International Biohydrometallurgy Symposium, Cape Town, South Africa, 25-29 September 2005; Harrison, S.T.L., Rawlings, D.E., Petersen, J., Eds.; IBS: Cape Town, South Africa, 2005; pp. 19-28.

143. Razzell, W.E.; Trussell, P.C. Isolation and properties of an iron-oxidizing Thiobacillus. J. Bacteriol. 1963, 85, 595-603.

144. Harahuc, L.; Lizama, H.; Suzuki, I. Effect of anions on selective solubilisation of zinc and copper in bacterial leaching of sulfide ores. Biotechnol. Bioeng. 2000, 69, 196-203.

145. Andrews, G.F.; Noah, K.S.; Glenn, A.Q.; Stevens, C.J. Combined physical/microbial beneficiation of coal using the flood/drain bioreactor. Fuel Process. Technol. 1994, 40, 283-296.

146. Andrews, G.F.; Noah, K.S. The flood/drain bioreactor for coal and mineral processing. In Mineral Bioprocessing II; Holmes, D.S., Smith, R.W., Eds.; TMS: Warrendale, PA, USA, 1995; pp. 219-230.

147. Andrews, G.F.; Stevens, C.J.; Glenn, A.; Noah, K.S. Microbial coal depyritization: Why and how? In Biohydrometallurgical Technologies; Torma, A.E., Wey, J.E., Lakshmanan, V.L., Eds.; TMS: Warrendale, PA, USA, 1993; pp. 381-391.

148. Andrews, G. The optimal design of bioleaching processes. Miner. Process. Extr. Metall. Rev. 1998, 19, 149-165.

149. Tyagi, R.D.; Couillard, D.; Tran, F.T. Comparative study of bacterial leaching of metals from sewage sludge in continuous stirred tank and airlift reactors. Process Biochem. 1991, 26, 47-54.

150. Chen, S.Y.; Lin, J.G. Bioleaching of heavy metals from contaminated sediment by indigenous sulfur-oxidizing bacteria in an air-lift bioreactor: Effects of sulfur concentration. Water Res. 2004, 38, 3205-3214. 
151. Puhakka, J.; Tuovinen, O.H. Biological leaching of sulfide minerals with the use of shake flask, aerated column, airlift reactor, and percolation techniques. Acta Biotechnol. 1986, 6, 345-354.

152. Miller, P.C.; Huberts, R.; Livesey-Goldblatt, E. The semicontinuous bacterial agitated leaching of nickel sulphide material. In Fundamental and Applied Biohydrometallurgy; Lawrence, R.W., Branion, R.M.R., Ebner, H.G., Eds.; Elsevier: Amsterdam, The Netherlands, 1986; pp. 23-42.

153. Sethurajan, M.; Aruliah, R.; Karthikeyan, O.P.; Balasubramanian, R. Bioleaching of copper from black shale ore using mesophilic mixed populations in an airlift reactor. Environ. Eng. Manag. J. 2012, 11, 1839-1848.

154. Slavkina, O.V.; Fomchencko, N.V.; Biriukov, V.V.; Arkhipov, M.Y. Study on bacterial leaching of copper-zinc ore concentrate. 3. Experimental trial of two-stage recirculation technology of copper-zinc concentrate leaching. Biotekhnologiya 2005, 3, 48-54.

155. Li, D.; Li, D.W.; Zhang, S.J. The study of toxic elements removal and valuable metals recovery from mine tailings in gas-liquid-solid internal circulation bioreactor. Res. J. Chem. Environ. 2011, 15, 990-993.

156. Loi, G.; Mura, A.; Trois, P.; Rossi, G. Bioreactor performance vs. Solids concentration in coal biodepyritization. Fuel Process. Technol. 1994, 40, 251-260.

157. Loi, G.; Trois, P.; Rossi, G. Biorotor ${ }^{\circledR}$ : A new development for biohydrometallurgical processing. In Biohydrometallurgical Processing; Vargas, T., Jerez, C.A., Wiertz, J.V., Toledo, H., Eds.; University of Chile: Santiago, Chile, 1995; Volume I, pp. 263-271.

158. Rossi, G. The design of bioreactors. Hydrometallurgy 2001, 59, 217-231.

159. Loi, G.; Rossi, A.; Trois, P.; Rossi, G. Continuous revolving barrel bioreactor tailored to the bioleaching microorganisms. Miner. Metall. Process. 2006, 23, 196-202.

160. Groudev, S.; Groudeva, V.I. Microbial communities in four industrial copper dump leaching operations in Bulgaria. FEMS Microbiol. Rev. 1993, 11, 261-267.

161. Brierley, J.A.; Brierley, C.L. Present and future commercial applications of biohydrometallurgy. Hydrometallurgy 2001, 59, 233-239.

162. Duncan, D.W.; Bruynesteyn, A. Enhancing bacterial activity in a uranium mine. Can. Min. Metall. Bull. 1971, 64, 32-36.

163. McCready, R.G.L.; Gould, W.D. Bioleaching of uranium at Denison Mines. In Biohydrometallurgy; Sally, J., McCready, R.G.L., Wichlacz, P.L., Eds.; Canmet: Ottawa, ON, Canada, 1989; pp. 477-485.

164. Domic, E. A review of the development and current status of copper bioleaching operations in Chile: 25 years of successful commercial implementation. In Biomining; Rawlings, D.E., Johnson, D.B., Eds.; Springer-Verlag: Berlin, Germany, 2007; pp. 81-95.

165. Brierley, C.L.; Brierley, J.A. Progress in bioleaching: Part B: Applications of microbial processes by the minerals industries. Appl. Microbiol. Biotechnol. 2013, 97, 7543-7552.

166. Logan, T.; Seal, T.; Brierley, J.A. Whole-ore heap biooxidation of sulfidic gold-bearing ores. In Biomining; Rawlings, D.E., Johnson, D.B., Eds.; Springer-Verlag: Berlin, Germany, 2007; pp. 113-138.

167. Readett, D.; Fox, F. Commercialisation of Ni heap leaching at Murrin Murrin operations. In Proceedings of the XXV International Mineral Processing Congress, Brisbane, Australia, 6-10 September 2010; AusIMM: Melbourne, Australia, 2010; pp. 3611-3616. 
168. Fernandes, H.M.; Lamego Simoes Filho, F.F.; Perez, V.; Ramalho Franklin, M.; Gomiero, L.A. Radioecological characterization of a uranium mining site located in a semi-arid region of Brazil. J. Environ. Radioact. 2006, 88, 140-157.

169. Lizama, H.M.; Harlamovs, J.R.; Belanger, S.; Brienne, S.H. The Teck Cominco Hydrozinc ${ }^{\mathrm{TM}}$ Process. In Hydrometallurgy 2003; Young, C., Alfantazi, A.M., Anderson, C.G., Dreisinger, D.B., Harris, B., James, A., Eds.; TMS: Warrendale, PA, USA, 2003; Volume 2, pp. 1503-1516.

170. Harvey, T.J.; Bath, M. The Geobiotics GEOCOAT ${ }^{\circledR}$ technology_Progress and challenges. In Biomining; Rawlings, D.E., Johnson, D.B., Eds.; Springer-Verlag: Berlin, Germany, 2007; pp. $97-112$.

171. Gunn, M.; Tittes, P.; Harvey, P.; Carretero, E.; da Silva, P.M.; de Souza, J.P. Laboratory and demonstration-scale operation of the Caraiba heap leach using GEOCOAT ${ }^{\circledR}$. In Hydrocopper 2009; Casas, J., Domic, E., Eds.; Gecamin: Santiago, Chile, 2009; pp. 352-364.

172. Williams, T.L.; Gunn, M.J.; Jaffer, A.; Harvey, P.I.; Tittes, P.R. The application of Geobiotics LLC GEOCOAT $^{\circledR}$ technology to the bacterial oxidation of a refractory arsenopyrite gold concentrate. In Hydrometallurgy 2008; Young, C.A., Taylor, P.R., Anderson, C.G., Choi, Y., Eds.; SME: Littleton, CO, USA, 2008; pp. 474-483.

173. Sampson, M.I.; van der Merwe, J.W.; Harvey, T.J.; Bath, M.D. Testing the ability of a low-grade sphalerite concentrate to achieve autothermality during biooxidation heap leaching. Miner. Eng. 2005, 18, 427-437.

174. Soleimani, M.; Petersen, J.; Roostaazad, R.; Hosseini, S.; Mousavi, S.M.; Najafi, A.; Kazemi Vasiri, A. Leaching of a zinc ore and concentrate using the Geocoat ${ }^{\mathrm{TM}}$ technology. Miner. Eng. 2011, 24, 64-69.

175. Petersen, J.; Dixon, D.G. Competitive bioleaching of pyrite and chalcopyrite. Hydrometallurgy 2006, 83, 40-49.

176. Mwase, J.M.; Petersen, J.; Eksteen, J.J. A conceptual flow-sheet for heap leaching of platinum group metals (PGMs) from a low-grade ore concentrate. Hydrometallurgy 2012, 111-112, 129-135.

177. Cope, L.W. Vat leaching-An overlooked process. Eng. Min. J. 1999, 200, 17-24.

178. Mackie, D.; Trask, F. Continuous vat leaching-First copper pilot trials. In ALTA Copper-X, Perth, Australia; ALTA Metallurgical Services: Melbourne, Australia, 2009.

179. Schlitt, J.; Johnston, A. The Marcobre vat leach system: A new look at an old process. In Proceedings of Copper 2010, Hamburg, Germany, 6-10 June 2010; GDMB: Clausthal-Zellerfeld, Germany, 2010; Volume 5, pp. 2039-2057.

180. Van Aswegen, P.C.; van Niekerk, J.; Olivier, W. The BIOX ${ }^{\mathrm{TM}}$ process for the treatment of refractory gold concentrates. In Biomining; Rawlings, D.E., Johnson, D.B., Eds.; Springer-Verlag: Berlin, Germany, 2007; pp. 1-33.

181. Miller, P.C. The design and operating practice of bacterial oxidation plant using moderate thermophiles (The BacTech Process). In Biomining: Theory, Microbes and Industrial Processes; Rawlings, D.E., Ed.; Springer-Verlag: Berlin, Germany, 1997; pp. 81-102.

182. Rorke, G.V.; Basson, P.; Miller, D.M. Advancements in thermophile bioleaching technology. In ALTA Nickel/Cobalt-7 Technical Proceedings; ALTA: Melbourne, Australia, 2001.

183. Batty, J.D.; Rorke, G.V. Development and commercial demonstration of the BioCOPTM thermophile process. Hydrometallurgy 2006, 83, 83-89. 
184. Wang, S. Copper leaching from chalcopyrite concentrates. JOM 2005, 57, 48-51.

185. Miller, D.M.; Dew, D.W.; Norton, A.E.; Johns, M.W.; Cole, P.M.; Benetis, G.; Dry, M. The BioNIC Process: Description of the process and presentation of pilot plant results. In Nickel/Cobalt 97; Cooper, W.C., Mihaylov, I., Eds.; CIM: Montreal, QC, Canada, 1997; Volume 1, pp. 97-110.

186. Gilbertson, B.P. Creating value through innovation: Biotechnology in mining. Miner. Process. Extr. Metall. 2000, 109, 61-67.

187. Morin, D.H.R.; d'Hugues, P. Bioleaching of a cobalt-containing pyrite in stirred tank reactors: A case study from laboratory scale to industrial application. In Biomining; Rawlings, D.E., Johnson, D.B., Eds.; Springer-Verlag: Berlin, Germany, 2007; pp. 35-55.

188. Romero, R.; Palencia, I.; Carranza, F. Silver catalysed IBES process: Application to a Spanish copper-zinc sulphide concentrate: Part 3. Selection of the operational parameters for a continuous pilot plant. Hydrometallurgy 1998, 49, 75-86.

189. Frias, C.; Carranza, F.; Sanchez, F.; Mazuelos, A.; Frades, M.; Romero, R.; Diaz, G.; Iglesias, N. New developments in indirect bioleaching of zinc and lead sulphide concentrates. In Hydrometallurgy 2008; Young, C.A., Taylor, P.R., Anderson, C.G., Choi, Y., Eds.; SME: Littleton, CO, USA, 2008; pp. 497-505.

190. Zafiratos, J.G.; Agatzini-Leonardou, S. Aerobic and anaerobic leaching of manganese. In Biohydrometallurgy: A Sustainable Technology in Evolution; Tsezos, M., Hatzikioseyian, A., Remoundaki, E., Eds.; National Technical University of Athens: Athens, Greece, 2004; pp. 41-54.

191. Ritcey, G.M. Solvent extraction in hydrometallurgy: Present and future. Tsinghua Sci. Technol. 2006, 11, 137-152.

192. Alexandros, S.D. Ion-exchange resins: A Retrospective from Industrial and Engineering Chemistry Research. Ind. Eng. Chem. Res. 2009, 48, 388-398.

193. Sole, K.C.; Cole, P.M.; Feather, A.M.; Kotze, M.H. Solvent extraction and ion exchange applications in Africa's resurging uranium industry: A review. Solvent Extr. Ion Exch. 2011, 29, 868-899.

194. Van Deventer, J. Selected ion exchange applications in the hydrometallurgical industry. Solvent Extr. Ion Exch. 2011, 29, 695-718.

195. Torma, A.E. Microbiological oxidation of synthetic cobalt, nickel and zinc sulfides by Thiobacillus ferrooxidans. Rev. Can. Biol. 1971, 30, 209-216.

196. Third, K.A.; Cord-Ruwisch, R.; Watling, H.R. The role of iron-oxidizing bacteria in stimulation or inhibition of chalcopyrite bioleaching. Hydrometallurgy 2000, 57, 225-233.

197. Fowler, T.A.; Crundwell, F.K. Leaching of zinc sulfide by Thiobacillus ferrooxidans: Bacterial oxidation of the sulfur product layer increases the rate of zinc sulfide dissolution at high concentrations of ferrous ions. Appl. Environ. Microbiol. 1999, 65, 5285-5292.

198. Zhang, G.; Fang, Z. The contribution of direct and indirect actions in bioleaching of pentlandite. Hydrometallurgy 2005, 80, 59-66.

199. King, A.J.; Budden, J.R. The bacterial oxidation of nickel and cobalt polymetallic concentrates. In Proceedings of the Nickel/Cobalt Pressure Leaching and Hydrometallurgy Forum, Perth, Australia, 13-14 May 1996; ALTA Metallurgical Services: Melbourne, Australia, 1996. 
200. Gómez, C.; Blázquez, M.L.; Ballester, A. Bioleaching of a Spanish complex sulphide ore bulk concentrate. Miner. Eng. 1999, 12, 93-106.

201. Pradhan, D.; Kim, D.J.; Chaudhury, G.R. Dissolution kinetics of complex sulfides acidophilic microorganisms. Jpn. Inst. Met. Mater. Trans. 2010, 51, 413-419.

202. Kim, D.J.; Pradhan, D.; Roy Chaudhury, G.; Ahn, J.G.; Lee, S.W. Bioleaching of complex sulfides concentrate and correlation of leaching parameters using multivariate data analysis technique. Jpn. Inst. Met. Mater. Trans. 2009, 50, 2318-2322.

203. Wang, Y.; Su, L.; Zeng, W.; Qiu, G.; Wan, L.; Chen, X.; Zhou, H. Optimization of copper extraction for bioleaching of complex $\mathrm{Cu}$-polymetallic concentrate by moderate thermophiles. Trans. Nonferr. Met. Soc. China 2014, 24, 1161-1170.

204. Uryga, A.; Sadowski, Z.; Grotowski, A. Bioleaching of cobalt from mineral products. Physicochem. Probl. Miner. Process. 2004, 38, 291-299.

205. Tasa, A.; Garcia, O.; Bigham, J.M.; Vuorinen, A.; Tuovinen, O.H. Acid and biological leaching of a black shale from Toolse, Estonia. In Biohydrometallurgical Processing; Vargas, T., Jerez, C.A., Wiertz, J.V., Toledo, H., Eds.; University of Chile: Santiago, Chile, 1995; Volume I, pp. 229-238.

206. Abdollahi, H.; Shaefaei, S.Z.; Noaparast, M.; Manafi, Z.; Aslan, N. Bio-dissolution of Cu, Mo and $\mathrm{Re}$ from molybdenite concentrate using a mix mesophilic microorganism in shake flask. Trans. Nonferr. Met. Soc. China 2013, 23, 219-230.

207. Gericke, M.; Muller, H.H.; van Staden, P.J.; Pinches, A. Development of a tank bioleaching process for the treatment of complex $\mathrm{Cu}$-polymetallic concentrates. Hydrometallurgy 2008, 94, 23-28.

208. Mehta, K.D.; Pandey, B.D. Bioleaching of a copper sulphide concentrate by two different strains of acidophilic bacteria. Int. J. Metall. Eng. 2012, 1, 83-86.

209. Norris, P.R.; Burton, N.P.; Clark, D.A. Mineral sulfide concentrate leaching in high temperature bioreactors. Miner. Eng. 2013, 48, 10-19.

210. Fomchenko, N.V.; Biryukov, V.V. A two-stage technology for bacterial and chemical leaching of copper-zinc raw materials by $\mathrm{Fe}^{3+}$ ions with their subsequent regeneration by chemolithotrophic bacteria. Appl. Biochem. Microbiol. 2009, 1, 56-60.

211. Fomchenko, N.V.; Muravyev, M.I.; Kondrat'eva, T.F. Two-stage bacterial-chemical oxidation of refractory gold-bearing sulfidic concentrates. Hydrometallurgy 2010, 101, 28-34.

212. Patel, B.C.; Tipre, D.R.; Dave, S.R. Development of Leptospirillum ferriphilum dominated consortium for ferric iron regeneration and metal bioleaching under extreme stresses. Bioresour. Technol. 2012, 118, 483-489.

213. Spolaore, P.; Joulian, C.; Gouin, J.; Ibáñez, A.; Augé, T.; Morin, D.; d'Hugues, P. Bioleaching of an organic-rich polymetallic concentrate using stirred-tank technology. Hydrometallurgy 2009, 99, 137-143.

214. Conic, V.T.; Cvetkovski, V.B.; Stanojevich Simsic, Z.S.; Dragulovic, S.S.; Ljubomirovic, Z.S.; Cvetkovska, M.; Vukovic, M.N. Bioleaching of Zn-Pb-Ag sulphidic concentrate. In Proceedings of the 15th International Research/Expert Conference "Trends in the Development of Machinery and Associated Technology” (TMT 2011), Prague, Czech Republic, 12-18 September 2011. 
215. Askari Zamani, M.A.; Hiroyoshi, N.; Tsunekawa, M.; Vaghar, R.; Oliazadeh, M. Bioleaching of Sarcheshmeh molybdenite concentrate for extraction of rhenium. Hydrometallurgy 2005, 80, 23-31.

216. Askari Zamani, M.A.; Vaghar, R.; Oliazadeh, M. Selective copper dissolution during bioleaching of molybdenite concentrate. Int. J. Miner. Process. 2006, 81, 105-112.

217. Langhans, D.L.; Baglin, E.G. Biological oxidation of a platinum-group metal flotation concentrate and converter matte. In Biohydrometallurgical Technologies; Torma, A.E., Wey, J.E., Lakshmanan, V.L., Eds.; TMS: Warrendale, PA, USA, 1993; pp. 315-325.

218. Romano, P.; Blázquez, M.L.; Alguacil, F.J.; Muñoz, J.A.; Ballester, A.; González, F. Comparative study on the selective chalcopyrite bioleaching of a molybdenite concentrate with mesophilic and thermophilic bacteria. FEMS Microbiol. Lett. 2001, 196, 71-75.

219. Dymov, I.; Ferron, C.J.; Philips, W. The development of a hybrid biological leaching-Pressure oxidation process for auriferous arsenopyrite/pyrite feedstocks. In Biohydrometallurgy: A Sustainable Technology in Evolution; Tsezos, M., Hatzikioseyian, A., Remoundaki, E., Eds.; National Technical University of Athens: Athens, Greece, 2004; pp. 377-386.

220. Tipre, D.R.; Vora, S.B.; Dave, S.R. Comparison of air-lift and stirred tank batch and semicontinuous bioleaching of polymetallic bulk concentrate. In Biohydrometallurgy: $A$ Sustainable Technology in Evolution; Tsezos, M., Hatzikioseyian, A., Remoundaki, E., Eds.; National Technical University of Athens: Athens, Greece, 2004; pp. 211-218.

221. Tipre, D.R.; Dave, S.R. Bioleaching process for $\mathrm{Cu}-\mathrm{Pb}-\mathrm{Zn}$ bulk concentrate at high pulp density. Hydrometallurgy 2004, 75, 37-43.

222. Okibe, N.; Gericke, M.; Hallberg, K.B.; Johnson, D.B. Enumeration and characterization of acidophilic microorganisms isolated from a pilot plant stirred-tank bioleaching operation. Appl. Environ. Microbiol. 2003, 69, 1936-1943.

223. Pivovarova, T.A.; Melamud, V.S.; Savari, E.E.; Sedel'nikova, G.V.; Kondrat'eva, T.F. Species and strain composition of microbial associations oxidizing different types of gold-bearing concentrates. Appl. Microbiochem. Microbiol. 2012, 46, 497-504.

224. D’Hugues, P.; Joulian, C.; Spolaore, P.; Michel, C.; Garrido, F.; Morin, D. Continuous bioleaching of a pyrite concentrate in stirred reactors: Population dynamics and exopolysaccharides production vs. Bioleaching performances. Hydrometallurgy 2008, 94, 34-41.

225. Hao, C.; Wang, L.; Dong, H.; Zhang, H. Succession of acidophilic bacterial community during bio-oxidation of refractory gold-containing sulfides. Geomicrobiol. J. 2010, 27, 683-691.

226. Wang, J.; Zhao, H.; Zhuang, T.; Qin, W.; Zhu, S.; Qiu, G. Bioleaching of Pb-Zn-Sn chalcopyrite concentrate in tank bioreactor and microbial community succession analysis. Trans. Nonferr. Met. Soc. China 2013, 23, 3758-3762.

227. Attia, Y.A.; El-Zeky, M. Effects of galvanic interactions on sulfides on extraction of precious metals from refractory complex sulfides by bioleaching. Int. J. Miner. Process. 1990, 30, 99-111.

228. D’Hugues, P.; Norris, P.R.; Hallberg, K.B.; Sanchez, F.; Langwaldt, J.; Grotowski, A.; Chmielewski, T.; Groudev, S.; Bioshale Consortium. Bioshale FP6 European project: Exploiting black shale ores using biotechnologies? Miner. Eng. 2008, 21, 111-120. 
229. Langwaldt, J. Bioleaching of multimetal black shale by thermophilic micro-organisms. In Biohydrometallurgy: From Single Cell to the Environment; Schippers, A., Sand, W., Glombitza, F., Willscher, S., Eds.; TransTech Publications: Zurich, Switzerland, 2007; p. 167.

230. Spolaore, P.; Joulian, C.; Gouin, J.; Sanchez, F.; Auge, T.; Morin, D.; d'Hugues, P. Continuous bioleaching of a polymetallic black shale concentrate using the stirred tank technology. In Proceedings of the XXIV International Mineral Processing Congress, Beijing, China, 24-28 September 2008; Wang, D., Sun, C., Wang, F., Zhan, L., Han, L., Eds.; Science Press: Beijing, China, 2008; pp. 2576-2584.

231. Spolaore, P.; Joulian, C.; Ménard, Y.; d'Hugues, P. Non-traditional operating conditions for a copper concentrate continuous bioleaching. In BioHydromet 10; MEI: Falmouth, UK, 2010; pp. 156-174.

232. Beane, R.; Ramey, D. In-situ leaching at the San Manuel porphyry copper deposit, Arizona, USA. In Copper 95-Cobre 95; Cooper, W.C., Dreisinger, D.B., Dutrizac, J.E., Hein, H., Ugarte, G., Eds.; MetSoc CIM: Montreal, QC, Canada, 1995; Volume III, pp. 363-375.

233. Rossi, G. Potassium recovery through leucite bioleaching: Possibilities and limitations. In Metallurgical Applications of Bacterial Leaching and Related Microbiological Phenomena; Murr, L.E., Torma, A.E., Brierley, J.A., Eds.; Academic Press: New York, NY, USA, 1978; pp. 297-319.

234. Gallant, A.; Wadden, D.G. The in-place leaching or uranium at Denison Mines. Can. Metall. $Q$. 1984, 24, 127-134.

235. Groudeva, V.I.; Groudev, S.N. Combined bacterial and chemical leaching of a polymetallic sulfide ore. In Mineral Bioprocessing; Smith, R.W., Misra, M., Eds.; TMS: Warrendale, PA, USA, 1991; pp. 153-161.

236. Korehi, H.; Schippers, A. Bioleaching of a marine hydrothermal sulfide ore with mesophiles, moderate thermophiles and thermophiles. In Integrating Scientific and Industrial Knowledge on Biohydrometallurgy; Guiliani, N., Demergasso, C., Quatrini, R., Remonsellez, F., Davis-Belmar, C., Levican, G., Parada, P., Barahona, C., Zale, R., Eds.; TransTech Publications: Zurich, Switzerland, 2013; pp. 229-232.

237. Hunter, C. BioHeap ${ }^{\mathrm{TM}}$ leaching of a primary nickel-copper sulphide ore. In Nickel-Cobalt-8 Technical Proceedings, Perth, Australia; ALTA Metallurgical Services: Melbourne, Australia, 2002.

238. Riekkola-Vanhanen, M. Talvivaara Sotkamo mine-Bioleaching of a polymetallic nickel ore in subarctic climate. Nova Biotechnol. 2010, 10, 7-14.

239. Wen, J.K.; Ruan, R.; Guo, X.J. Heap leaching-An option of treating nickel sulfide ore and laterite. In Proceedings of the Nickel/Cobalt Conference, Perth, Australia, 15-17 May 2006; ALTA Metallurgical Services: Melbourne, Australia, 2006.

240. Norton, A.E.; Coetzee, J.J.; Barnett, C.C. BioNIC ${ }^{\circledR}$ : An economically competitive process for the biological extraction of nickel. In Proceedings of the Nickel/Cobalt Pressure Leaching and Hydrometallurgy Forum, Perth, Australia, 25-27 May 1998; Metallurgical Services: Melbourne, Australia, 1998.

241. Watling, H.R.; Elliot, A.D.; Maley, M.; van Bronswijk, W.; Hunter, C. Leaching of a low-grade, copper-nickel sulfide ore. 1 . Key parameters impacting on $\mathrm{Cu}$ recovery during column bioleaching. Hydrometallurgy 2009, 97, 204-212. 
242. Maley, M.; van Bronswijk, W.; Watling, H.R. Leaching of a low-grade, copper-nickel sulfide ore. 2. Impact of aeration and $\mathrm{pH}$ on $\mathrm{Cu}$ recovery during abiotic leaching. Hydrometallurgy 2006, 98, 66-72.

243. Maley, M.; van Bronswijk, W.; Watling, H.R. Leaching of a low-grade, copper-nickel sulfide ore. 3. Interactions of $\mathrm{Cu}$ with selected sulfide minerals. Hydrometallurgy 2009, 98, 73-80.

244. Elliot, A.D.; Watling, H.R. Chalcopyrite formation through the metathesis of pyrrhotite with aqueous copper. Geochim. Cosmochim. Acta 2011, 75, 2103-2118.

245. Cameron, R.A.; Lastra, R.; Mortazavi, S.; Bedard, P.L.; Morin, L.; Gould, W.D.; Kennedy, K.J. Bioleaching of a low-grade ultramafic nickel sulphide ore in stirred-tank reactors at elevated $\mathrm{pH}$. Hydrometallurgy 2009, 97, 213-220.

246. Cameron, R.A.; Lastra, R.; Mortazavi, S.; Gould, W.D.; Thibault, Y.; Bédard, P.L.; Morin, L.; Kennedy, K.J. Elevated-pH bioleaching of a low-grade ultramafic nickel sulphide ore in stirred-tank reactors at 5 to $45^{\circ} \mathrm{C}$. Hydrometallurgy 2009, 99, 77-83.

247. Cameron, R.A.; Yeung, C.W.; Greer, C.W.; Gould, W.D.; Mortazavi, S.; Bédard, PL.; Morin, L.; Lortie, L.; Dinardo, O.; Kennedy, K.J.; et al. The bacterial structure during bioleaching of a low-grade nickel sulphide ore in stirred tank reactors at different combinations of temperature and pH. Hydrometallurgy 2010, 104, 207-215.

248. Cameron, R.A.; Lastra, R.; Gould, W.D.; Mortazavi, S.; Thibault, Y.; Bédard, P.L.; Morin, L.; Koren, D.W.; Kennedy, K.J. Bioleaching of six nickel sulphide ores with differing mineralogies in stirred tank reactors at $30{ }^{\circ} \mathrm{C}$. Miner. Eng. 2013, 49, 172-183.

249. Qin, W.; Zhen, S.; Yan, Z.; Campbell, M.; Wang, J.; Liu, K.; Zhang, Y. Heap bioleaching of a low-grade nickel-bearing sulfide ore containing high levels of magnesium as olivine, chlorite and antigorite. Hydrometallurgy 2009, 98, 58-65.

250. Miller, P.C. Large scale bacterial leaching of a copper-zinc ore in situ. In Fundamental and Applied Biohydrometallurgy; Lawrence, R.W., Branion, R.M.R., Ebner, H.G., Eds.; Elsevier: Amsterdam, The Netherlands, 1986; pp. 215-239.

251. Oros, V.; Peterfi, M.; Bivolaru, M.; Kovacs, S.; Straut, I.; Jelea, M.; Hudrea, I. Production of copper and zinc by microbial in situ stope leaching at Ilba mine, (Romania). In Proceedings of the 9th International Symposium on Biohydrometallurgy, Troia, Portugal, 9-13 September 1991; Duarte, J.C., Lawrence, R.W., Eds.; Forbitec: Queluz, Portugal, 1991.

252. Sand, W.; Hallmann, R.; Rohde, K.; Sobotke, B.; Wentzien, S. Controlled microbiological in-situ stope leaching of a sulphidic ore. Appl. Microbiol. Biotechnol. 1993, 40, 421-426.

253. Krafft, C.; Hallberg, R.O. Bacterial leaching of two Swedish zinc sulfide ores. FEMS Microbiol. Rev. 1993, 11, 121-128.

254. Brauckmann, B.; Poppe, W.; Beyer, W.; Lerche, R.; Steppke, H.D. Investigations of increased biological in-situ leaching of the "Old Deposit" of the Preussag Rammelsberg ore mine. In Biohydrometallurgy; Norris, P.R., Kelly, D.P., Eds.; Science and Technology Letters: Kew, UK, 1988; pp. 521-523.

255. Burton, C.; Cowman, S.; Heffernan, J.; Thorne, B. In-situ bioleaching of sulphide ores at Avoca, Ireland: Part I. Development, characterization and operation of a medium-scale (6000 t) experimental leach site. In Recent Progress in Biohydrometallurgy; Rossi, G., Torma, A.E., Eds.; Associazone Mineraria Sarda: Iglesias, Italy, 1983; pp. 243-264. 
256. Zhen, S.; Qin, W.; Yan, Z.; Zhang, Y.; Wang, J.; Ren, L. Bioleaching of low-grade nickel sulfide mineral in column reactor. Trans. Nonferr. Met. Soc. China 2008, 18, 1480-1484.

257. Giaveno, A.; Lavalle, L.; Chiacchiarini, P.; Donati, E. Bioleaching of zinc from low-grade complex sulfide ores in an airlift by isolated Leptospirillum ferrooxidans. Hydrometallurgy 2007, 89, 117-126.

258. Chen, J.W.; Gao, C.J.; Zhang, Q.X.; Xiao, L.S.; Zhang, G.Q. Leaching of nickel-molybdenum sulfide ore in membrane biological reactor. Trans. Nonferr. Met. Soc. China 2011, 21, 1395-1401.

259. Lizama, H.M.; Oh, J.K.; Takeuchi, T.L.; Suzuki, I. Bacterial leaching of copper and zinc from a sulfide ore by a mixed culture of Thiobacillus ferrooxidans and Thiobacillus thiooxidans in laboratory scale and pilot plant scale columns. In Biohydrometallurgy; Salley, J., McCready, R.G.L., Wichlacz, P.L., Eds.; Canmet: Ottawa, ON, Canada, 1989; pp. 519-531.

260. Groudev, S.N. Complex utilization of polymetallic sulphide ores by means of combined bacterial and chemical leaching. In Harnessing Biotechnology for the 21st Century; Ladsich, M.R., Bose, A., Eds.; American Chemical Society: Washington, DC, USA, 1992; pp. 454-457.

261. Sandström, Å.; Petersson, S. Bioleaching of a complex sulphide ore with moderate thermophilic and extreme thermophilic microorganisms. Hydrometallurgy 1997, 46, 181-190.

262. Liao, M.X.; Deng, T.L. Zinc and lead from complex sulfides by sequential bioleaching and acidic brine leach. Miner. Eng. 2004, 17, 17-22.

263. Radio Hill and Sholl Heap Leaching Project. Available online: www.foxresources.com.au/radiohill-sholl-heap.asp (accessed on 22 October 2014).

264. Lippmaa, E.; Maremae, E.; Pihlak, A.T. Resources, production and processing of Baltoscandian multimetal black shales. Oil Shale 2011, 28, 68-77.

265. Ketris, M.P.; Yudovich, Y.E. Estimations of Clarkes for carbonaceous biolithes: World averages for trace element contents in black shales and coals. Int. J. Coal Geol. 2009, 78, 135-148.

266. Watling, H.R.; Collinson, D.M.; Shiers, D.W.; Bryan, C.G.; Watkin, E.L.J. Effects of temperature and solids loading on microbial community structure during batch culture on a polymetallic ore. Miner. Eng. 2013, 48, 68-76.

267. Watling, H.R.; Collinson, D.M.; Fjastad, S.; Kaksonen, A.H.; Li, J.; Morris, C.; Perrot, F.A.; Rea, S.M.; Shiers, D.W. Column bioleaching of a polymetallic ore: Effects of $\mathrm{pH}$ and temperature on metal extraction and microbial community structure. Miner. Eng. 2014, 58, 90-99.

268. Choi, M.S.; Cho, K.S.; Kim, D.S.; Ryu, H.W. Bioleaching of uranium from low-grade schists by Acidithiobacillus ferrooxidans. World J. Microbiol. Biotechnol. 2005, 21, 377-380.

269. Anjum, F.; Bhatti, H.N.; Ambreen, A. Bioleaching of black shale by Acidithiobacillus ferrooxidans. Asian J. Chem. 2009, 21, 5251-5266.

270. Pal, S.; Pradhan, D.; Das, T.; Sukla, L.B.; Roy Chaudhury, G. Bioleaching of low-grade uranium ore using Acidithiobacillus ferrooxidans. Indian J. Microbiol. 2010, 50, 70-75.

271. Riekkola Vanhanen, M.; Heimala, S. Study of the bioleaching of a nickel-containing black-schist ore. In Biohydrometallurgy and the Environment toward the Mining of the 21st Century; Amils, R., Ballester, A., Eds.; Elsevier: Amsterdam, The Netherlands, 1999; pp. 533-542.

272. Technical Report on the Polymetallic Black Shale SBH Property, Birch Mountains, Athabasca Region, Alberta, Canada. Available online: www.dnimetals.com/pdf/TechRpt_SBHpty-AB_Dumont-2008.pdf (accessed on 22 October 2014). 
273. Anjum, F.; Shahid, M.; Akcil, A. Biohydrometallurgy techniques of low grade ores: A review on black shale. Hydrometallurgy 2012, 117-118, 1-12.

274. Aziz, A.; Sajjad, M.; Mohammad, B. Elemental characterization of black shales of Khyber Pakthunkhawa (KPK) region of Pakistan using AAS. Chin. J. Geochem. 2013, 32, 248-251.

275. Developing High Margin Uranium Projects. Available online: www.auraenergy.com.au/assets/ Aura_Roadshow_Presentation_January_2014.pdf (accessed on 22 October 2014).

276. Jowitt, S.M.; Keays, R.R. Shale-hosted Ni-(Cu-PGE) mineralisation: A global overview. Trans. Inst. Min. Metall. Appl. Earth Sci. 2011, 120, 187-197.

277. Major Base Metal Districts Favourable for Future Bioleaching Technologies. Final Report to the Bioshale Project WP6. Available online: http://infoterre.brgm.fr/rapports/RP-55610-FR.pdf (accessed 22 October 2014).

278. Pašava, J.; Hladiková, J.; Dobeš, P. Origin of Proterozoic metal-rich black shales from the Bohemian Massif, Czech Republic. Econ. Geol. 1996, 91, 63-79.

279. Pašava, J.; Zaccharini, F.; Aiglsperger, T.; Vymazalová, A. Platinum group elements (PGE) and their principal carriers in metal-rich black shales: An overview with new data from Mo-Ni-PGE black shales (Zunyi region, Guizhou Province, south China). J. Geosci. 2013, 58, 209-216.

280. Norris, P.R.; Brown, C.F.; Caldwell, P.E. Ore column leaching with thermophiles: II, polymetallic sulfide ore. Hydrometallurgy 2012, 127-128, 70-76.

281. Norris, P.R.; Gould, O.; Ogden, T. Anaerobic microbial growth to enhance iron removal from a polymetallic sulfide ore from 30 to $75^{\circ} \mathrm{C}$. In Proceedings of Biohydrometallurgy 2014, Falmouth, UK, 9-11 June 2014.

282. Kalinowski, B.E.; Oskarsson, A.; Albinsson, Y.; Arlinger, J.; Ödegaard-Jensen, A.; Andlid, T.; Pederson, K. Microbial leaching of uranium and other trace elements from shale mine tailings at Ranstad. Geoderma 2004, 122, 177-194.

283. Mishra, A.; Pradhan, N.; Kar, R.N.; Sukla, L.B.; Mishra, B.K. Microbial recovery of uranium using native fungal strains. Hydrometallurgy 2009, 95, 175-177.

284. Abd El Wahab, G.M.; Amin, M.M.; Aita, S.K. Bioleaching of uranium-bearing material from Abu Thor area, West Central Sinai, Egypt, for recovering uranium. Arab J. Nucl. Sci. Appl. 2012, 45, 169-178.

285. Anjum, F.; Bhatti, H.N.; Asgher, M.; Shahid, M. Leaching of metal ions from black shale by organic acids produced by Aspergillus niger. Appl. Clay Sci. 2010, 47, 356-361.

286. Bhatti, H.N.; Sarwar, S.; Ilyas, S. Effect of organic acids produced by Penicillium notatum on the extraction of metals ions from brown shale. J. Chem. Soc. Pak. 2012, 34, 1040-1047.

287. Nouren, S.; Bhatti, H.N.; Ilyas, S. Bioleaching of copper, aluminium, magnesium and manganese from brown shale by Ganoderma lucidum. Afr. J. Biotechnol. 2011, 10, 10664-10673.

288. Anjum, F.; Bhatti, H.N.; Ghauri, M.A.; Bhatti, I.A.; Asgher, M.; Asi, M.R. Bioleaching of copper, cobalt and zinc from black shale by Penicillium notatum. Afr. J. Biotechnol. 2009, 8, 5038-5045.

289. Anjum, F.; Bhatti, H.N.; Ghauri, M.A. Enhanced bioleaching of metals from black shale using ultrasonics. Hydrometallurgy 2010, 100, 122-128. 
290. Sjoberg, V.; Grandin, A.; Karlsson, L.; Karlsson, S. Bioleaching of shale-Impact of carbon source. In The New Uranium Mining Boom; Merkel, B., Schipek, M., Eds.; Springer-Verlag: Berlin, Germany, 2011; pp. 449-454.

291. Hsu, K.J.; Sun, S.; Li, J.L.; Chen, H.H.; Pen, H.P.; Sengor, A.M.C. Mesozoic overthrust tectonics in south China. Geology 1988, 16, 418-421.

292. Morin, D.H.R.; Pinches, T.; Huisman, J.; Frias, C.; Norberg, A.; Forssberg, E. Progress after three years of BioMinE-Research and Technological Development project for a global assessment of biohydrometallurgical processes applied to European non-ferrous metal resources. Hydrometallurgy 2008, 94, 58-68.

293. Loukola-Ruskeeniemi, K. Geochemistry and genesis of the black-shale hosted Ni-Cu-Zn deposit at Talvivaara, Finland. Econ. Geol. 1996, 91, 80-110.

294. Puhakka, J.A.; Kaksonen, A.H.; Riekkola-Vanhanen, M. Heap leaching of black schist. In Biomining; Rawlings, D.E., Johnson, D.B., Eds.; Springer: Berlin, Germany, 2007; pp. 139-151.

295. Salo-Zieman, V.L.A.; Kinnunen, P.H.M.; Puhakka, J.A. Bioleaching of acid-consuming low-grade nickel ore with elemental sulfur addition and subsequent acid generation. J. Chem. Technol. Biotechnol. 2006, 81, 34-40.

296. Halinen, A.K.; Rahunen, N.; Kaksonen, A.H.; Puhakka, J.A. Heap bioleaching of a complex sulfide ore. Part I: Effect of $\mathrm{pH}$ on metal extraction and microbial composition in $\mathrm{pH}$ controlled columns. Hydrometallurgy 2009, 98, 92-100.

297. Halinen, A.K.; Rahunen, N.; Kaksonen, A.H.; Puhakka, J.A. Heap bioleaching of a complex sulfide ore. Part II: Effect of temperature on base metal extraction and bacterial compositions. Hydrometallurgy 2009, 98, 101-107.

298. Bhatti, T.M.; Bigham, J.M.; Riekkola-Vanhanen, M.; Tuovinen, O.H. Altered mineralogy associated with stirred tank bioreactor leaching of a black schist ore. Hydrometallurgy 2010, 100, 181-184.

299. Bhatti, T.M.; Bigham, J.M.; Vuorinen, A.; Tuovinen, O.H. Chemical and bacterial leaching of metals from black schist sulfide minerals in shake flasks. Int. J. Miner. Process. 2012, 110-111, 25-29.

300. Bhatti, T.M.; Vuorinen, A.; Tuovinen, O.H. Dissolution of non-sulfide phases during the chemical and bacterial leaching of a sulfidic black schist. Hydrometallurgy 2012, 117-118, 32-35.

301. Wakeman, K.; Auvinen, H.; Johnson, D.B. Microbiological and geochemical dynamics in simulated-heap leaching of a polymetallic sulfide ore. Biotech. Bioeng. 2008, 101, 739-750.

302. Halinen, A.K.; Beecroft, N.J.; Määttä, K.; Nurmi, P.; Laukkanen, K.; Kaksonen, A.H.; Riekkola-Vanhanen, M.; Puhakka, J.A. Microbial community dynamics during a demonstration-scale bioheap leaching operation. Hydrometallurgy 2013, 125-126, 34-41.

303. Updated Resource Estimate and Preliminary Economic Assessment Estimate Viken Project NPV at US \$1 Billion. Available online: www.CZQminerals.com/news-releases/page/2/ (accessed on 22 October 2014).

304. Investment Presentation: High Impact Exploration in a World-Class Producing Copper-Nickel Region. Available online: www.finnaustmining.com/ (accessed on 22 October 2014).

305. Alberta Black Shale Metals Projects. Available online: www.dnimetals.com/properties/ black_shales.htm (accessed on 22 October 2014). 
306. Vaughan, D.J.; Sweeney, M.; Friedrich, G.; Diedel, R.; Haranczyk, C. The Kupferschiefer: An overview with an appraisal of the different types of mineralization. Econ. Geol. 1989, 84, 1003-1027.

307. Sadowski, Z.; Szubert, A. Comparison of kinetics of black shale bioleaching process using stationary and agitated systems. Physicochem. Probl. Miner. Process. 2007, 41, 387-395.

308. Grobelski, T.; Farbiszewska-Kiczma, J.; Farbiszewska, T. Bioleaching of Polish black shale. Physicochem. Probl. Miner. Process. 2007, 41, 259-264.

309. Groudev, S.N.; Spasova, I.I.; Nicolova, M.V.; Georgiev, P.S. Bacterial leaching of black shale copper ore. Adv. Mater. Res. 2007, 50, 187-190.

310. Farbiszewska, T.; Farbiszewska-Kiczma, J.; Bak, M. Biological extraction of metals from a Polish black shale. Physicochem. Probl. Miner. Process. 2003, 37, 51-56.

311. BioMOre: An Alternative Mining Concept-Raw Materials Commitment. Available online: https://ec.europa.eu/eip/raw-materials/en/content/biomore-alternative-mining-concept-raw-materialscommitment (accessed on 22 October 2014).

312. Taylor, A. Laterites-Still a Frontier of Nickel Process Development. Paper Presented at TMS2013, San Antonio, Texas, USA, 3-7 March 2013. Available online: http://www.altamet. com.au/wp-content/uploads/2013/04/laterites-still-a-frontier-of-nickel-process-development1.pdf (accessed on 22 October 2014).

313. Zhang, W.; Cheng, C.Y. Manganese metallurgy review. Part 1: Leaching of ores/secondary materials and recovery of electrolytic/chemical manganese dioxide. Hydrometallurgy 2007, 89, $137-159$.

314. Das, A.P.; Sukla, L.B.; Pradhan, N.; Nayak, S. Manganese biomining: A review. Bioresour. Technol. 2011, 102, 7381-7387.

315. Bacon, W.G.; Dalvi, A.D.; Rochon, B.A.; Selby, M. Nickel outlook-2000-2010. Cim Bull. 2002, 95, 47-52.

316. Tzeferis, P.G.; Agatzini-Leonardou, S. Leaching of nickel and iron from Greek non-sulphide nickeliferous ores by organic acids. Hydrometallurgy 1994, 36, 345-360.

317. Tzeferis, P.G.; Agatzini, S.; Nerantzis, E.T. Mineral leaching of non-sulphide nickel ores using heterotrophic microorganisms. Lett. Appl. Microbiol. 1994, 18, 209-213.

318. Agatzini, S.; Tzeferis, P. Bioleaching of nickel-cobalt oxide ores. AusIMM Proc. 1997, 1, 9-15.

319. Sukla, L.B.; Panchanadikar, V.V.; Kar, R.N. Microbial leaching of lateritic nickel ore. World J. Microbiol. Biotechnol. 1993, 9, 255-257.

320. Sukla, L.B.; Panchanadikar, V.V. Bioleaching of lateritic nickel ore using an indigenous microflora. In Biohydrometallurgical Technologies; Torma, A.E., Wey, J.E., Lakshmanan, V.L., Eds.; TMS: Warrendale, PA, USA, 1993; Volume 1, pp. 373-380.

321. Sukla, L.B.; Panchanadikar, V. Bioleaching of lateritic nickel ore using a heterotrophic micro-organism. Hydrometallurgy 1993, 32, 373-379.

322. Sukla, L.B.; Swamy, K.M.; Narayana, K.L.; Kar, R.N.; Panchanadikar, V.V. Bioleaching of Sukinda laterite using ultrasonics. Hydrometallurgy 1995, 37, 387-391.

323. Sukla, L.B.; Kar, R.N.; Panchanadikar, V.V.; Choudhury, S.; Mishra, R.K. Bioleaching of lateritic nickel ore using Penicillium sp. Trans. Indian Inst. Met. 1995, 48, 103-106. 
324. Valix, M.; Tang, J.Y.; Cheung, W.H. The effects of mineralogy on the biological leaching of nickel laterite ores. Miner. Eng. 2001, 14, 1629-1635.

325. Valix, M.; Tang, J.Y.; Malik, R. Heavy metal tolerance of fungi. Miner. Eng. 2001, 14, 499-505.

326. Valix, M.; Loon, L.O. Adaptive tolerance behaviour of fungi in heavy metals. Miner. Eng. 2003, 16, 193-198.

327. Valix, M.; Thangavalu, V.; Ryan, D.; Tang, J. Using halotolerant Aspergillus foetidus in bioleaching nickel laterite ore. Int. J. Environ. Waste Manag. 2009, 3, 253-264.

328. Tang, J.A.; Valix, M. Leaching of low grade limonite and nontronite ores by fungi metabolic acids. Miner. Eng. 2006, 19, 1274-1279.

329. Tang, J.; Valix, M. Leaching kinetics of limonite and nontronite ores. Int. J. Environ. Waste Manag. 2009, 3, 244-252.

330. Thangavalu, V.; Tang, J.; Ryan, D.; Valix, M. Effect of saline stress on fungi metabolism and biological leaching of weathered saprolite ores. Miner. Eng. 2006, 19, 1266-1273.

331. Simate, G.S.; Ndlovu, S. Characterisation of factors in the bacterial leaching of nickel laterites using statistical design of experiments. In Biohydrometallurgy: From Single Cell to the Environment; Schippers, A., Sand, W., Glombitza, F., Willscher, S., Eds.; TransTech Publications: Zurich, Switzerland, 2007; pp. 66-69.

332. Simate, G.S.; Ndlovu, S.; Gericke, M. Bacterial leaching of nickel laterites using chemolithotrophic microorganisms: Process optimisation using response surface methodology and central composite rotatable design. Hydrometallurgy 2009, 98, 241-246.

333. Watling, H.R.; Elliot, A.D.; Fletcher, H.M.; Robinson, D.J.; Sully, D.M. Ore mineralogy of nickel laterites: Controls on processing characteristics under simulated heap-leach conditions. Aust. J. Earth Sci. 2011, 58, 725-744.

334. Imai, K. On the mechanism of bacterial leaching. In Metallurgical Applications of Bacterial Leaching and Related Phenomena; Murr, L.E., Torma, A.E., Brierley, J.A., Eds.; Academic Press: New York, NY, USA, 1978; pp. 275-295.

335. Nakazawa, H.; Sato, H. Bacterial leaching of cobalt-rich ferromanganese crusts. Int. J. Miner. Process. 1995, 43, 255-265.

336. Belyi, A.V.; Pustochilov, P.P.; Gurevich, Y.L.; Kadochnikova, G.G.; Ladygina, V.P. Bacterial leaching of manganese ores. Appl. Biochem. Microbiol. 2006, 42, 289-292.

337. Kai, T.; Taniguchi, S.; Ikeda, S.I.; Takahashi, T. Effect of Thiobacillus ferrooxidans during redox leaching of manganese nodules and nickel sulfide. Resour. Environ. Biotechnol. 1996, 1, 99-1009.

338. Konishi, Y.; Asai, S. Leaching of marine manganese nodules by acidophilic bacteria growing on elemental sulfur. Metall. Mater. Trans. B 1997, 28, 25-32.

339. Ndlovu, S.; Simate, G.S.; Gericke, M. The microbial assisted leaching of nickel laterites using a mixed culture of chemolithotrophic microorganisms. In Biohydrometallurgy: A Meeting Point between Microbial Ecology, Metal Recovery Processes and Environmental Remediation; Donati, E.R., Viera, M.R., Tavani, E.L., Giaveno, M.A., Lavalle, T.L., Chiaccharini, P.A., Eds.; TransTech Publications: Zurich, Switzerland, 2009; pp. 493-496.

340. Kumari, A.; Natarajan, K.A. Bioleaching of ocean manganese nodules in the presence of reducing agents. Eur. J. Miner. Process. Environ. Prot. 2001, 1, 10-24. 
341. Jain, N.; Sharma, D.K. Biohydrometallurgy for nonsulfidic minerals-A review. Geomicrobiol. J. 2004, 21, 135-144.

342. Dave, S.R.; Natarajan, K.A.; Bhat, J.V. Leaching of copper and zinc from oxidised ores by fungi. Hydrometallurgy 1981, 7, 235-242.

343. Groudev, S.N.; Groudeva, V.I. Biological leaching of aluminium from clays. In Biotechnology for the Mining, Metal-Refining, and Fossil Fuel Processing Industries; Ehrlich, H.L., Holmes, D.S., Eds.; John Wiley and Sons: New York, NY, USA, 1986; pp. 91-96.

344. Mohapatra, S.; Bohidar, S.; Pradhan, N.; Kar, R.N.; Sukla, L.B. Microbial extraction of nickel from Sukinda chromite overburden by Acidithiobacillus ferrooxidans and Aspergillus strains. Hydrometallurgy 2007, 85, 1-8.

345. Das, C.; Mehta, K.D.; Pandey, B.D. Biochemical leaching of metals from Indian Ocean nodules by Aspergillus niger. Miner. Process. Technol. 2005, 8, 460-467.

346. McKenzie, D.I.; Denys, L.; Buchanan, A. The solubilisation of nickel, cobalt and iron from laterites by means of organic chelating agents at low pH. Int. J. Miner. Process. 1987, 21, 275-292.

347. Das, A.P.; Swain, S.; Panda, S.; Pradhan, N.; Sukla, L.B. Reductive acid leaching of low-grade manganese ores. Geomaterials 2012, 2, 70-72.

348. Burgstaller, W.; Schinner, F. Leaching of metals with fungi. J. Biotechnol. 1993, 27, 91-116.

349. Le, L.; Tang, J.; Ryan, D.; Valiz, M. Bioleaching nickel laterite ores using multi-metal tolerant Aspergillus foetidus organism. Miner. Eng. 2006, 19, 1259-1265.

350. Veglio, F.; Beolchini, F.; Gasbarro, A.; Toro, L.; Ubaldini, S.; Abbruzzese, C. Batch and semi-continuous tests in the bioleaching of manganiferous minerals by heterotrophic mixed microorganisms. Int. J. Miner. Process. 1997, 50, 255-273.

351. Mukherjee, A.; Raichur, A.M.; Modak, J.M.; Natarajan, K.A. A novel bio-leaching process to recover valuable metals from Indian Ocean nodules using a marine isolate. In Biohydrometallurgy: A Sustainable Technology in Evolution; Tsezos, M., Hatzikioseyian, A., Remoundaki, E., Eds.; National Technical University of Athens: Athens, Greece, 2004; pp. 25-33.

352. Lovley, D.R. Organic matter mineralization with the reduction of ferric iron: A review. Geomicrobiol. J. 1987, 5, 375-399.

353. Lovley, D.R. Microbial reduction of iron, manganese and other metals. Adv. Agron. 1995, 54, $175-231$.

354. Lovley, D.R.; Coates, J.D. Novel forms of anaerobic respiration of environmental relevance. Curr. Opin. Microbiol. 2000, 3, 252-256.

355. Eisele, T.C.; Gabby, K.L. Review of reductive leaching of iron by anaerobic bacteria. Miner. Process. Extr. Metall. Rev. 2014, 35, 75-105.

356. Lee, E.Y.; Noh, S.R.; Cho, K.S. Leaching of Mn, Co and Ni from manganese nodules using an anaerobic bioleaching method. J. Biosci. Bioeng. 2001, 92, 354-359.

357. Agate, A.D. Recent advances in microbial mining. World J. Microbiol. Biotechnol. 1996, 12, 487-495.

358. Ehrlich, H.L. Ocean manganese nodules: Biogenesis and bioleaching possibilities. Miner. Metall. Process. 2000, 17, 121-128. 
359. Urrutia, M.M.; Roden, E.E.; Fredrickson, J.K.; Zachara, J.M. Microbial and surface chemistry controls on reduction of synthetic Fe(III) oxide minerals by the dissimilatory iron-reducing bacterium Shewanella alga. Geomicrobiol. J. 1998, 15, 269-291.

360. Cummings, D.E.; Caccavo, F.; Fendorf, S.; Rosenzweig, R.F. Arsenic mobilization by the dissimilatory Fe(III) reducing bacterium Shewanella alga BrY. Environ. Sci. Technol. 1999, 33, $723-729$.

361. Liu, C.; Gorby, Y.A.; Zachara, J.M.; Fredrickson, J.K.; Brown, C.F. Reduction kinetics of $\mathrm{Fe}(\mathrm{III}), \mathrm{Co}(\mathrm{III}), \mathrm{U}(\mathrm{VI})$ and $\mathrm{Tc}(\mathrm{VII})$ in cultures of dissimilatory metal-reducing bacteria. Biotechnol. Bioeng. 2002, 80, 637-649.

362. Konishi, Y.; Saitoh, N.; Ogi, T. A new biohydrometallurgical method for processing of deep-sea mineral resources. In Proceedings of the ASME 2009 28th International Conference on Ocean, Offshore and Arctic Engineering (OMAE2009), Honolulu, HI, USA, 31 May-5 June 2009; ASME: New York, NY, USA, 2009; Volume 4B, pp. 1319-1324.

363. Brand, N.W.; Butt, C.R.M.; Elias, M. Nickel laterites: Classification and features. AGSO J. Aust. Geol. Geophys. 1998, 17, 81-88.

364. Freyssinet, P.; Butt, C.R.M.; Morris, R.C.; Piantone, P. Ore-forming processes related to laterite weathering. In Economic Geology 100th Anniversary Volume; Hedenquist, J.W., Thomson, J.F.H., Goldfarb, R.J., Richards, J.P., Eds.; Economic Geology Publishing Company: New Haven, CT, USA, 2005; pp. 681-722.

365. Du Plessis, C.A.; Slabbert, W.; Hallberg, K.B.; Johnson, D.B. Ferredox: A biohydrometallurgical processing concept for limonitic nickel laterites. Hydrometallurgy 2011, 109, 221-229.

366. Dold, B. Sustainability in metal mining: From exploration, over processing to mine waste management. Rev. Environ. Sci. Biotechnol. 2008, 7, 275-285.

367. Mudd, G.M. Sustainability and Mine Waste Management-A Snapshot of Mining Waste Issues. Available online: http://users.monash.edu.au/ gmudd/files/2007-WasteMment-Sustainability-vMineWastes.pdf (accessed on 22 October 2014).

368. Shaw, R.A.; Petravratzi, E.; Bloodworth, A.J. Resource recovery from mine waste. In Waste as a Resource; Hester, R.M., Harrison, R.M., Eds.; Royal Society of Chemistry: Cambridge, UK, 2013; pp. 44-65.

369. Olson, G.J.; Brierley, C.L.; Briggs, A.P.; Calmet, E. Biooxidation of thiocyanate-containing refractory gold tailings from Minacalpa, Peru. Hydrometallurgy 2006, 81, 159-166.

370. Thomas, J.; Subramanian, S.; Riyaz Ulla, M.S.; Louis, K.T.; Gundewar, C.S. Studies on the biodissolution of cobaltic pyrite from copper tailings. In Proceedings of the XXIII International Mineral Processing Congress, Istanbul, Turkey, 3-8 September 2006; Önal, G., Acarkan, N., Çelik, M.S., Arslan, F., Ateşok, G., Güney, A., Sirkeci, A.A., Yüce, A.E., Perek, K.T., Eds.; Promed Advertising Agency: Istanbul, Turkey, 2006; pp. 1329-1333.

371. Kitobo, W.; Ilunga, A.; Frenay, J.; Gaydardzhiev, S.; Basti, D. Bacterial leaching of complex sulphides from mine tailings altered by acid drainage. In Hydrocopper 2009; Casas, J., Domic, E., Eds.; Gecamin: Santiago, Chile, 2009; pp. 365-373. 
372. Muñoz, A.; Bevilaqua, D.; Garcia, O. Leaching of $\mathrm{Ni}$ and $\mathrm{Cu}$ from mine wastes (tailings and slags) using acid solutions of A. ferrooxidans. In Biohydrometallurgy: A Meeting Point between Microbial Ecology, Metal Recovery Processes and Environmental Remediation; Donati, E.R., Viera, M.R., Tavani, E.L., Giaveno, M.A., Lavalle, T.L., Chiaccharini, P.A., Eds. TransTech Publications: Zurich, Switzerland, 2009; pp. 425-428.

373. Zhu, J. Bacterial leaching research of Cu-Ni flotation tailing. In Biohydrometallurgy: Biotech Key to Unlock Mineral Resources Values; Qiu, G., Jiang, T., Qin, W., Liu, X., Yang, Y., Wang, H., Eds.; Central South University Press: Changsha, China, 2011; pp. 821-823.

374. Kondrat'eva, T.F.; Pivovarova, T.A.; Bulaev, A.G.; Melamud, V.S.; Muravyov, M.I.; Usoltsev, A.V.; Vasil'ev, E.A. Percolation bioleaching of copper and zinc and gold recovery from flotation tailings of the sulfide complex ores of the Ural region, Russia. Hydrometallurgy 2012, 111-112, 82-86.

375. Bulaev, A.G.; Muravyov, M.I.; Pivovarova, T.A.; Fomochenko, N.V. Bioprocessing of mining and metallurgical wastes containing non-ferrous and precious metals. In Integrating Scientific and Industrial Knowledge on Biohydrometallurgy; Guiliani, N., Demergasso, C., Quatrini, R., Remonsellez, F., Davis-Belmar, C., Levican, G., Parada, P., Barahona, C., Zale, R., Eds.; TransTech Publications: Zurich, Switzerland, 2013; pp. 301-304.

376. Galvez-Cloutier, R.; Mulligan, C.N.; Ouattra, A. Biolixiviation of $\mathrm{Cu}, \mathrm{Ni}, \mathrm{Pb}$ and $\mathrm{Zn}$ using organic acids by Aspergillus niger and Penicillium simplicissinum. In Biohydrometallurgy: A Sustainable Technology in Evolution; Tsezos, M., Hatzikioseyian, A., Remoundaki, E., Eds.; National Technical University of Athens: Athens, Greece, 2004; pp. 175-184.

377. Bryan, C.G.; Hallberg, K.B.; Johnson, D.B. Mobilisation of metals in mineral tailings at the abandoned Sao Domingos copper mine (Portugal) by indigenous acidophilic bacteria. Hydrometallurgy 2006, 83, 184-194.

378. Willscher, S.; Pohle, C.; Sitte, J.; Werner, P. Solubilization of heavy metals from a fluvial AMD generating tailings sediment by heterotrophic microorganisms. Part I: Influence of $\mathrm{pH}$ and solid content. J. Geochem. Explor. 2007, 92, 177-185.

379. Tan, G.L.; Shu, W.S.; Hallberg, K.B.; Li, F.; Lan, C.Y.; Zhou, W.H.; Huang, L.N. Culturable and molecular phylogenetic diversity of microorganisms in an open-dumped, extremely acidic $\mathrm{Pb} / \mathrm{Zn}$ mine tailings. Extremophiles 2008, 12, 657-664.

380. Tan, G.L.; Shu, W.S.; Hallberg, K.B.; Li, F.; Lan, C.Y.; Huang, L.N. Cultivation-dependent and cultivation-independent characterization of the microbial community in acid mine drainage associated with acidic $\mathrm{Pb} / \mathrm{Zn}$ tailings at Lechang, Guandong, China. FEMS Microbiol. Ecol. 2007, 59, 118-126.

381. Kock, D.; Schippers, A. Quantitative microbial community analysis of three different sulfidic mine tailing dumps generating acid mine drainage. Appl. Environ. Microbiol. 2008, 74, 5211-5219.

382. Costa, M.C.; Carvalho, N.; Iglesias, N.; Palencia, I. Bacterial leaching studies of a Portuguese flotation tailing. In Biohydrometallurgy: A Sustainable Technology in Evolution; Tsezos, M., Hatzikioseyian, A., Remoundaki, E., Eds.; National Technical University of Athens: Athens, Greece, 2004; pp. 75-84. 
383. Rivera-Santillan, R.E.; Becerril-Reyes, V. Comparison of the bioleaching effect of mesophilic $\left(35^{\circ} \mathrm{C}\right)$ and thermophilic $\left(45^{\circ} \mathrm{C}\right)$ bacteria on the Tizapa tailings. In Biohydrometallurgy: From the Single Cell to the Environment; Schippers, A., Sand, W., Glombitza, F., Willscher, S., Eds.; TransTech Publications: Zurich, Switzerland, 2007; pp. 34-37.

384. Nagy, A.A.; Gock, E.D.; Melcher, F.; Atmaca, T.; Hahn, L.; Schippers, A. Biooxidation and cyanidation for gold and silver recovery from acid mine drainage generating tailings (Ticapampa, Peru) In Biohydrometallurgy: From Single Cell to the Environment; Schippers, A., Sand, W., Glombitza, F., Willscher, S., Eds.; TransTech Publications: Zurich, Switzerland, 2007; pp. 91-94.

385. Schippers, A.; Nagy, A.A.; Kock, D.; Melcher, F.; Gock, E.D. The use of FISH and real time PCR to monitor the biooxidation and cyanidation for gold and silver recovery from mine tailings concentrate (Ticapampa, Peru). Hydrometallurgy 2008, 94, 77-81.

386. Tong, L.; Yang, H.; Liu, C. Bioleaching of Cu-Zn tailings. In Biohydrometallurgy: Biotech Key to Unlock Mineral Resources Values; Qiu, G., Jiang, T., Qin, W., Liu, X., Yang, Y., Wang, H., Eds.; Central South University Press: Changsha, China, 2011; pp. 793-797.

387. Liu, Y.G.; Zhou, M.; Zeng, G.M.; Li, X.; Xu, W.H.; Fan, T. Effect of solids concentration on removal of heavy metals from mine tailings via bioleaching. J. Hazard. Mater. 2007, 141, 202-208.

388. Liu, Y.G.; Zhou, M.; Zeng, G.M.; Wang, X.; Li, X.; Fan, T.; Xu, W.H. Bioleaching of heavy metals from mine tailings by indigenous sulfur-oxidizing bacteria: Effects of substrate concentration. Bioresour. Technol. 2008, 99, 4124-4129.

389. Nguyen, V.K.; Lee, J.U. Catalytic effect of activated charcoal on microbial extraction of arsenic and heavy metals from mine tailings. Geosci. J. 2014, 18, 355-363.

390. Mugire, F. Changing Lives: Chinese Investment in Uganda's Copper Mining Gives Hope to Thousands. Available online: http://english.people.com.cn/business/8568960.html (accessed on 22 October 2014).

391. Tollinsky, N. Bioleaching Plant Proposed for Cobalt. Available online: www.Sudburyminingsolutions.com/bioleaching-plant-proposed-for-Cobalt.html (accessed on 22 October 2014).

392. Miller, P. The use of bioleaching for cobalt/arsenic tailings remediation in Ontario Canada. In ALTA Ni-Co 2009, Perth, Australia; ALTA Metallurgical Services: Melbourne, Australia, 2009.

393. McEwan, K.N.; Ralph, D.E.; Savage, C.J. In-Situ Bio-Oxidation of Low-Grade Refractory Sulphide Minerals. World Patent 2002061155 A1, 30 January 2014.

394. McEwan, K.; Ralph, D. The i-BOTM process and related treatments for mine waste remediation. In Brownfield Sites; Brebbia, C.A., Almorza, D., Klapperich, H., Eds.; WIT Press: Southampton, UK, 2002; pp. 525-532.

395. Seh-Bardan, B.J.; Othman, R.; Ab Wahib, S.; Husin, A.; Sadegh-Zadeh, F. Column bioleaching of arsenic and heavy metals from gold mine tailings by Aspergillus fumigatus. Clean Soil Air Water 2012, 40, 607-614. 
396. Hernández, I.; Galizia, F.; Coto, O.; Donati, E. Improvement in metal recovery from laterite tailings by bioleaching. In Biohydrometallurgy: A Meeting Point between Microbial Ecology, Metal Recovery Processes and Environmental Remediation; Donati, E.R., Viera, M.R., Tavani, E.L., Giaveno, M.A., Lavalle, T.L., Chiaccharini, P.A., Eds.; TransTech Publications: Zurich, Switzerland, 2009; pp. 489-492.

397. Coto, O.; Galizia, F.; Hernandez, I.; Marrero, J.; Donati, E. Cobalt and nickel recoveries from laterite tailings by organic and inorganic bio-acids. Hydrometallurgy 2008, 94, 18-22.

398. Coto, O.; Schippers, A. Influence of sulfur source on nickel and cobalt bioleaching from laterite tailings using Acidithiobacillus thiooxidans. In Biohydrometallurgy: Biotech Key to Unlock Mineral Resources Values; Qiu, G., Jiang, T., Qin, W., Liu, X., Yang, Y., Wang, H., Eds.; Central South University Press: Changsha, China, 2011; pp. 579-583.

399. Cabrera, G.; Gomez, J.M.; Hernandez, I.; Coto, O.; Cantero, D. Different strategies for recovering metals from CARON process residue. J. Hazard. Mater. 2011, 189, 836-842.

400. Hernández Diaz, I.; Galizia, F.; Coto Perez, O. Reduction of heavy-metal content in overburden material by bacterial action. In Biohydrometallurgy: A Meeting Point between Microbial Ecology, Metal Recovery Processes and Environmental Remediation; Donati, E.R., Viera, M.R., Tavani, E.L., Giaveno, M.A., Lavalle, T.L., Chiaccharini, P.A., Eds.; TransTech Publications: Zurich, Switzerland, 2009; pp. 653-656.

401. Mulligan, C.N.; Galvez-Cloutier, R. Bioremediation of metal contamination. Environ. Monit. Assess. 2003, 84, 45-60.

402. Mulligan, C.N.; Kamali, M.; Gibbs, B.F. Bioleaching of copper and other metals from low-grade oxidized mining ores by Aspergillus niger. J. Chem. Technol. Biotechnol. 2003, 78, 497-503.

403. Behera, S.K.; Panda, P.P.; Singh, S.; Pradhan, N.; Sukla, L.B.; Mishra, B.K. Study on reaction mechanism of bioleaching of nickel and cobalt from lateritic chromite overburdens. Int. Biodeterior. Biodegrad. 2011, 65, 1035-1042.

404. Behera, S.K.; Sukla, L.B. Microbial extraction of nickel from chromite overburdens in the presence of surfactant. Trans. Nonferr. Met. Soc. China 2012, 22, 2840-2845.

405. Behera, S.K.; Panda, S.K.; Pradhan, N.; Sukla, L.B.; Mishra, B.K. Extraction of nickel by microbial reduction of laterite chromite overburden of Sukinda, India. Bioresour. Technol. 2012, $125,17-22$.

406. Johnson, D.B. Recent developments in microbiological approaches for securing mine wastes and for recovering metals from mine waters. Minerals 2014, 4, 279-292.

(C) 2014 by the author; licensee MDPI, Basel, Switzerland. This article is an open access article distributed under the terms and conditions of the Creative Commons Attribution license (http://creativecommons.org/licenses/by/4.0/). 